$\mathrm{DOE} / \mathrm{NV} / 10845-32$

UC-700

\title{
REVIEW OF PRESENT GROUNDWATER MONITORING PROGRAMS AT THE NEVADA TEST SITE
}

by

Ronald L. Hershey

David Gillespie

SEPTEMBER 1993

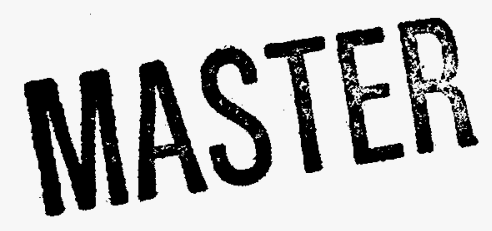

Publication \#451:16 
This report was prepared as an account of work sponsored by the United States Government. Neither the United States nor the United States Department of Energy, nor any of their employees, makes any warranty, express or implied, or assumes any legal liability or responsibility for the accuracy, completeness or usefulness of any information, apparatus, product or process disclosed, or represents that its use would not infringe privately owned rights. Reference herein to any specific commercial product, process, or service by trade name, mark, manufacturer, or otherwise, does not necessarily constitute or imply its endorsement, recommendation, or favoring by the United States Government or any agency thereof. The views and opinions of authors expressed herein do not necessarily state or reflect those of the United States Government or any agency thereof.

This report has been reproduced directly from the best available copy.

Available to DOE and DOE contractors from the Office of Scientific and Technical Information, P.O. Box 62, Oak Ridge, TN 37831; prices available from (615) 576-8401.

Available to the public from the National Technical Information Service, U.S. Department of Commerce, 5285 Port Royal Rd., Springfield, VA 22161. 


\section{DISCLAIMER}

Portions of this document may be illegible in electronic image products. Images are produced from the best available original document. 
DOE/NV/10845-32

UC-700

\title{
REVIEW OF PRESENT GROUNDWATER MONITORING PROGRAMS AT THE NEVADA TEST SITE
}

\author{
by \\ Ronald L. Hershey \\ David Gillespie \\ Water Resources Center \\ Desert Research Institute \\ University and Community College System of Nevada
}

Publication No. 45116

\author{
prepared for \\ Nevada Operations Office \\ U.S. Department of Energy \\ Las Vegas, Nevada
}

September 1993

The work upon which this report is based was supported by the U.S. Department of Energy under Contract \#DE-AC08-90NV10845. 


\section{CONTENTS}

LIST OF FIGURES $\ldots \ldots \ldots \ldots \ldots \ldots \ldots \ldots \ldots \ldots \ldots \ldots \ldots \ldots \ldots \ldots \ldots \ldots$

LIST OF TABLES $\ldots \ldots \ldots \ldots \ldots \ldots \ldots \ldots \ldots \ldots \ldots \ldots \ldots \ldots \ldots \ldots \ldots \ldots \ldots$

INTRODUCTION $\ldots \ldots \ldots \ldots \ldots \ldots \ldots \ldots \ldots \ldots \ldots \ldots \ldots \ldots \ldots \ldots$

HYDROGEOLOGY OF THE NEVADA TEST SITE . . . . . . . . . . . . . 1

POTENTIAL GROUNDWATER CONTAMINATION SOURCES . . . . . . . . 6

EXISTING GROUNDWATER MONITORING ACTIVITIES $\ldots \ldots \ldots \ldots \ldots \ldots \ldots$.

REECo's Environmental Monitoring Program $\ldots \ldots \ldots \ldots \ldots \ldots \ldots \ldots \ldots$

EMSL-LV's Long-Term Hydrologic Monitoring Program . . . . . . . . . . . 11

U.S. Geological Survey's Water-level Monitoring Program . . . . . . . . . . . 14

Other Groundwater Sampling Programs . .................... 14

RATIONALE FOR SPECIFIC CONSTITUENT MONITORING . . . . . . . . . . 14

Identification and Tracking of Radioactive Constituents ............. 14

Regulatory Requirements . . . . . . . . . . . . . . . . . . . . . . . . 17

Safe Drinking Water Act $\ldots \ldots \ldots \ldots \ldots \ldots \ldots \ldots \ldots \ldots \ldots \ldots$

Comprehensive Environmental Response, Compensation and Liability Act .. 19

Resource Conservation and Recovery Act ................... 20

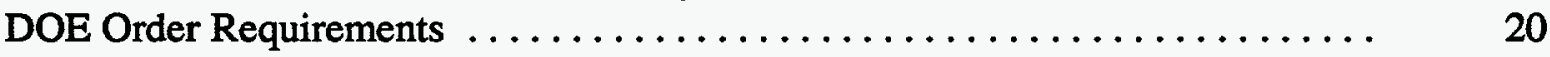

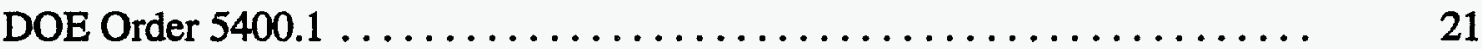

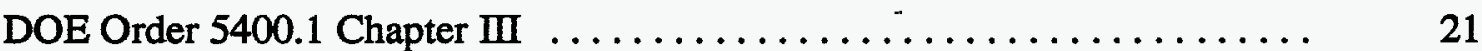

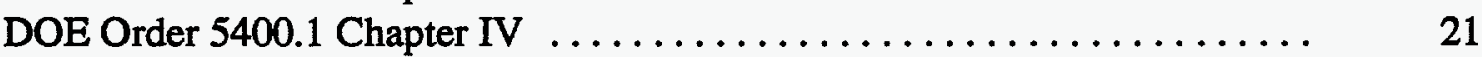

DOE Order 5400.4 CERCLA Requirements. ................... 22

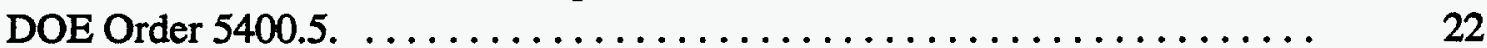

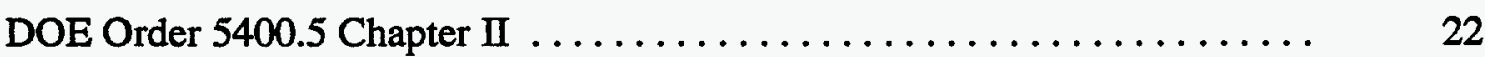

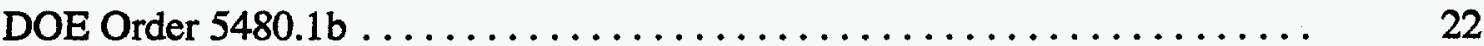

REVIEW OF NTS ANALYTICAL METHODS FOR TRITIUM ACTIVITY . . . . 23

Conventional Analytical Method for Tritium Activity $\ldots \ldots \ldots \ldots \ldots \ldots \ldots . \ldots$

Enrichment Analytical Method for Tritium Activity . . . . . . . . . . . . . 23

Qualitative Comparison of 1992 Enriched Tritium Results ............ 24

GROUNDWATER MONITORING NETWORK DESIGN CRITERIA . . . . . . . 27

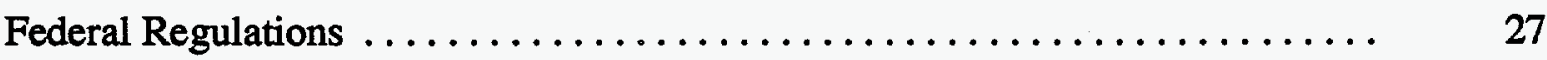

Methodology for Groundwater Monitoring Network Design ............ 28

Define Objectives of the Program ....................... 28

Identify Source Terms . . . . . . . . . . . . . . . . . . . . . . 29

Identify Receptor Sites . . . . . . . . . . . . . . . . . . . . . . . . . 29

Define Hdyrogeology ................................. 29

Define Existing Groundwater Quality . . . . . . . . . . . . . . . 30

Evaluate Distribution/Attenuation of Contamination $\ldots \ldots \ldots \ldots \ldots \ldots . \ldots . \ldots$

Prioritize Source Terms ............................ 30

Evaluate Existing Monitoring Programs $\ldots \ldots \ldots \ldots \ldots \ldots \ldots \ldots \ldots \ldots$ 
Select and Implement Monitoring Program $\ldots \ldots \ldots \ldots \ldots \ldots \ldots \ldots . . . \ldots \ldots \ldots$

Review and Interpret Monitoring Results $\ldots \ldots \ldots \ldots \ldots \ldots \ldots \ldots . . . \ldots \ldots$

Review and Revise Monitoring Program Based on Monitoring Results ...... 31

Summary of Methodology for Groundwater Monitoring Network Design ...... 32

Specific Nevada Test Site Design Considerations ................. 32

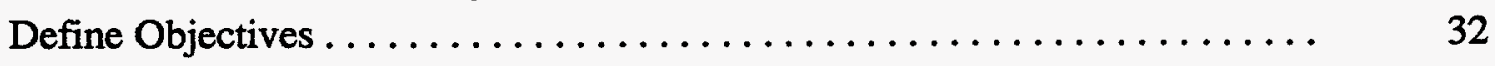

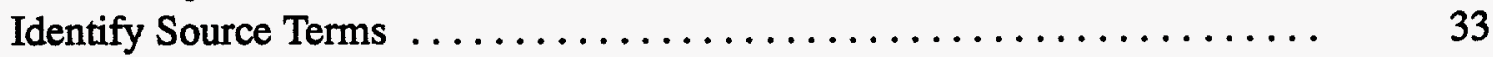

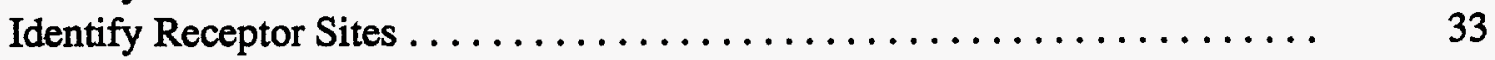

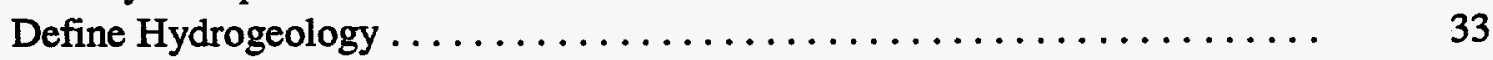

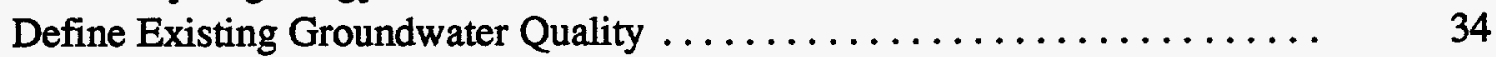

Evaluate Distribution/Attenuation of Contamination $\ldots \ldots \ldots \ldots \ldots \ldots . . \ldots \ldots$

Prioritize Source Terms .............................. 34

Evaluate Existing Groundwater Monitoring Programs $\ldots \ldots \ldots \ldots \ldots \ldots . \quad 34$

Review and Revise Monitoring Program $\ldots \ldots \ldots \ldots \ldots \ldots \ldots \ldots . . \ldots \ldots$

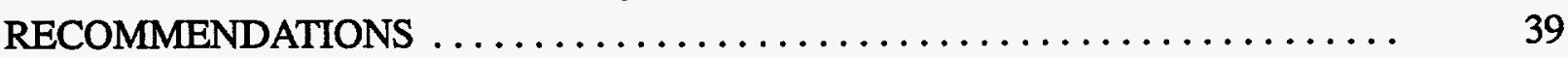

Sampling Frequency and Constituents to be Analyzed ................ 39

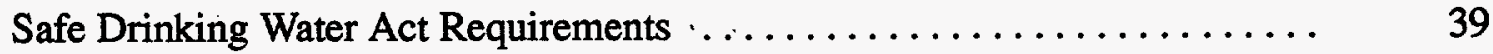

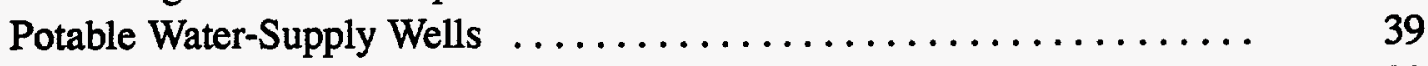

Non-Potable Water-Supply Wells $\ldots \ldots \ldots \ldots \ldots \ldots \ldots \ldots \ldots . . . \ldots \ldots$

Drinking-Water Consumption Points . . . . . . . . . . . . . . . 39

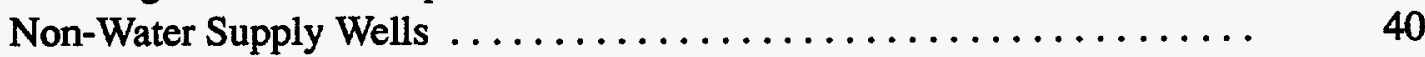

DOE Order Requirements ............................ 40

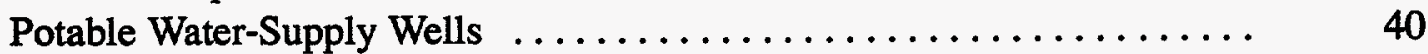

Non-Potable Water-Supply Wells $\ldots \ldots \ldots \ldots \ldots \ldots \ldots \ldots \ldots . .40$

Drinking-Water Consumption Points . . . . . . . . . . . $40 \ldots \ldots \ldots \ldots, \ldots$

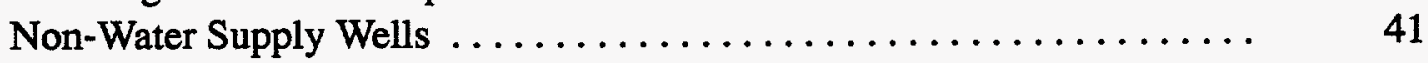

Analytical Methods for Tritium Analysis $\ldots \ldots \ldots \ldots \ldots \ldots \ldots \ldots \ldots \ldots, 41$

Groundwater Monitoring Network Design $\ldots \ldots \ldots \ldots \ldots \ldots \ldots \ldots \ldots, 41$

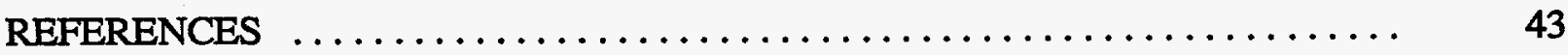

Appendix A. Announced Underground Nuclear Weapons Tests at the
Nevada Test Site Conducted Below or Near the Groundwater Table .. A-1

Appendix B. Safe Drinking Water Act Regulations ................. B-1

Appendix C. Tritium Analytical Methods $. \ldots \ldots \ldots \ldots \ldots \ldots \ldots \ldots \ldots . \quad \mathrm{C}-1$

Appendix D. Enriched Tritium Results of Groundwater Samples Collected by REECo and EMSL-LV in 1992 from Water-Supply Wells at the Nevada Test Site $\ldots \ldots \ldots \ldots \ldots \ldots \ldots \ldots \ldots \ldots \ldots \ldots \ldots \ldots$ D-1

Appendix E. U.S. Environmental Protection Agency Letter Recommending Enriched Tritium Interlaboratory Comparison Program ......... E-1

Appendix F. List of Potential Groundwater Monitoring Wells $\ldots \ldots \ldots \ldots \ldots$ F-1 


\section{LIST OF FIGURES}

1. Physiographic features at the Nevada Test Site $\ldots \ldots \ldots \ldots \ldots \ldots \ldots \ldots \ldots \ldots . \ldots \ldots$

2. Major rock types at the Nevada Test Site $\ldots \ldots \ldots \ldots \ldots \ldots \ldots \ldots \ldots \ldots \ldots \ldots$

3. Composite potentiometric surface and hydrographic subbasins at the

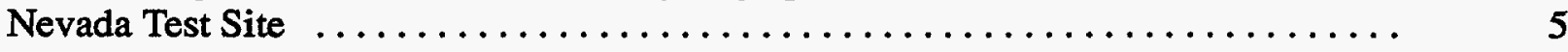

4. Underground nuclear testing locations at the Nevada Test Site ............. 7

5. Groundwater supply wells sampled in 1992 by REECo's

Environmental Monitoring Program at the Nevada Test Site $\ldots \ldots \ldots \ldots \ldots \ldots .9$

6. Groundwater wells sampled in 1992 by EMSL-LV at the Nevada Test Site . . . . . . 12

7. Groundwater wells where depth-to-water is measured by the USGS at the

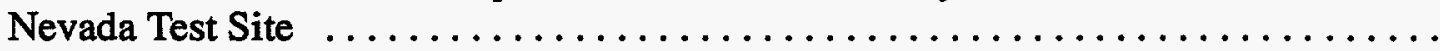

\section{LIST OF.TABLES}

1. Hydrostratigraphic Classification of Principal Lithologic Units Encountered at the

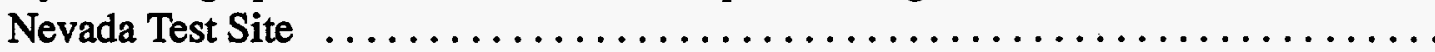

2. REECo'S 1992 Environmental Monitoring Program Sampling Schedule of Potable and Non-potable Water-supply Wells and Natural Springs at the

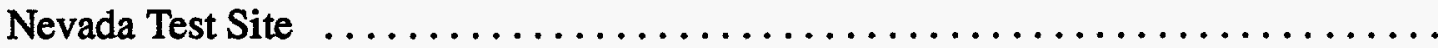

3. 1992 Water-supply Wells, Population, and Community/ Noncommunity Status of Public Drinking Water Systems at the Nevada Test Site $. . . \ldots \ldots \ldots .$.

4. EMSL-LV'S 1992 LTHMP Sampling Schedule of Wells at the Nevada Test Site ....

5. Underground Nuclear Weapons Testing Related Radionuclides with Long Half-lives that May be Present in Groundwater at the Nevada Test Site ..........

6. Selected 1992 enriched Tritium Results of Groundwater Samples Collected by REECo and EMSL-LV from Water-supply Wells Common to Each Monitoring Program $\ldots \ldots \ldots \ldots \ldots \ldots \ldots \ldots \ldots \ldots \ldots \ldots \ldots \ldots \ldots \ldots \ldots$

7. List of Potential Sampling Locations That Could Be Added to Existing Groundwater Sampling Network at the Nevada Test Site 


\section{INTRODUCTION}

Groundwater monitoring at the Nevada Test Site (NTS) is conducted to detect the presence of radionuclides produced by underground nuclear testing and to verify the quality and safety of groundwater supplies as required by the State of Nevada and federal regulations, and by U.S. Department of Energy (DOE) Orders. Groundwater is monitored at water-supply wells and at other boreholes and wells not specifically designed or located for traditional groundwater monitoring objectives. Different groundwater monitoring programs at the NTS are conducted by several DOE Nevada Operations Office (DOE/NV) contractors. Presently, these individual groundwater monitoring programs have not been assessed or administered under a comprehensive planning approach. Redundancy exists among the programs in both the sampling locations and the constituents analyzed. Also, sampling for certain radionuclides is conducted more frequently than required. The purpose of this report is to review the existing NTS groundwater monitoring programs and make recommendations for modifying the programs so a coordinated, streamlined, and comprehensive monitoring effort may be achieved by DOE/NV.

This review will be accomplished in several steps. These include: summarizing the present knowledge of the hydrogeology of the NTS and the potential radionuclide source areas for groundwater contamination; reviewing the existing groundwater monitoring programs at the NTS; examining the rationale for monitoring and the constituents analyzed; reviewing the analytical methods used to quantify tritium activity; discussing monitoring network design criteria; and synthesizing the information presented and making recommendations based on the synthesis. This scope of work was requested by the DOE/NV Hydrologic Resources Management Program (HRMP) and satisfies the 1993 (fiscal year) HRMP Groundwater Monitoring Program Review task.

\section{HYDROGEOLOGY OF THE NEVADA TEST SITE}

The NTS is located in southern Nevada in the Basin and Range physiographic province. The topography of the NTS is composed of four major basins, three large mesas, and a number of north-south-trending mountain ranges (Figure 1). The four major basins, located in the eastern and southern portion of the NTS, are Frenchman Flat, Yucca Flat, Jackass Flats, and Mercury Valley. The minimum elevations of these basins are $1200,1000,1100$, and 1000 meters above mean sea level, respectively. The three large mesas and their maximum elevations are Pahute Mesa (2256 meters), Buckboard Mesa (1848 meters), and Rainier Mesa (2324 meters). The major mountain ranges and their maximum elevations on the NTS include the Belted Range (2354 meters), Mercury Ridge (1608 meters), and the Halfpint Range (1539 meters). Isolated mountains and their maximum elevations such as Skull Mountain (1828 meters), Shoshone Mountain (2154 meters), and Yucca Mountain (1930 meters) are also present. The locations of these features are shown in Figure 1.

The geology at the NTS can be classified into three major rock types: complexly folded and faulted sedimentary rocks of Paleozoic age; volcanic tuffs and lavas of Tertiary age; and, Tertiary and Quaternary alluvium (Figure 2). The sedimentary rocks of Paleozoic age are hundreds to thousands of meters thick and consist primarily of carbonate rocks in the lower and upper section, separated by a thick sequence of clastic rocks (shale and quartzite). These Paleozoic-age 


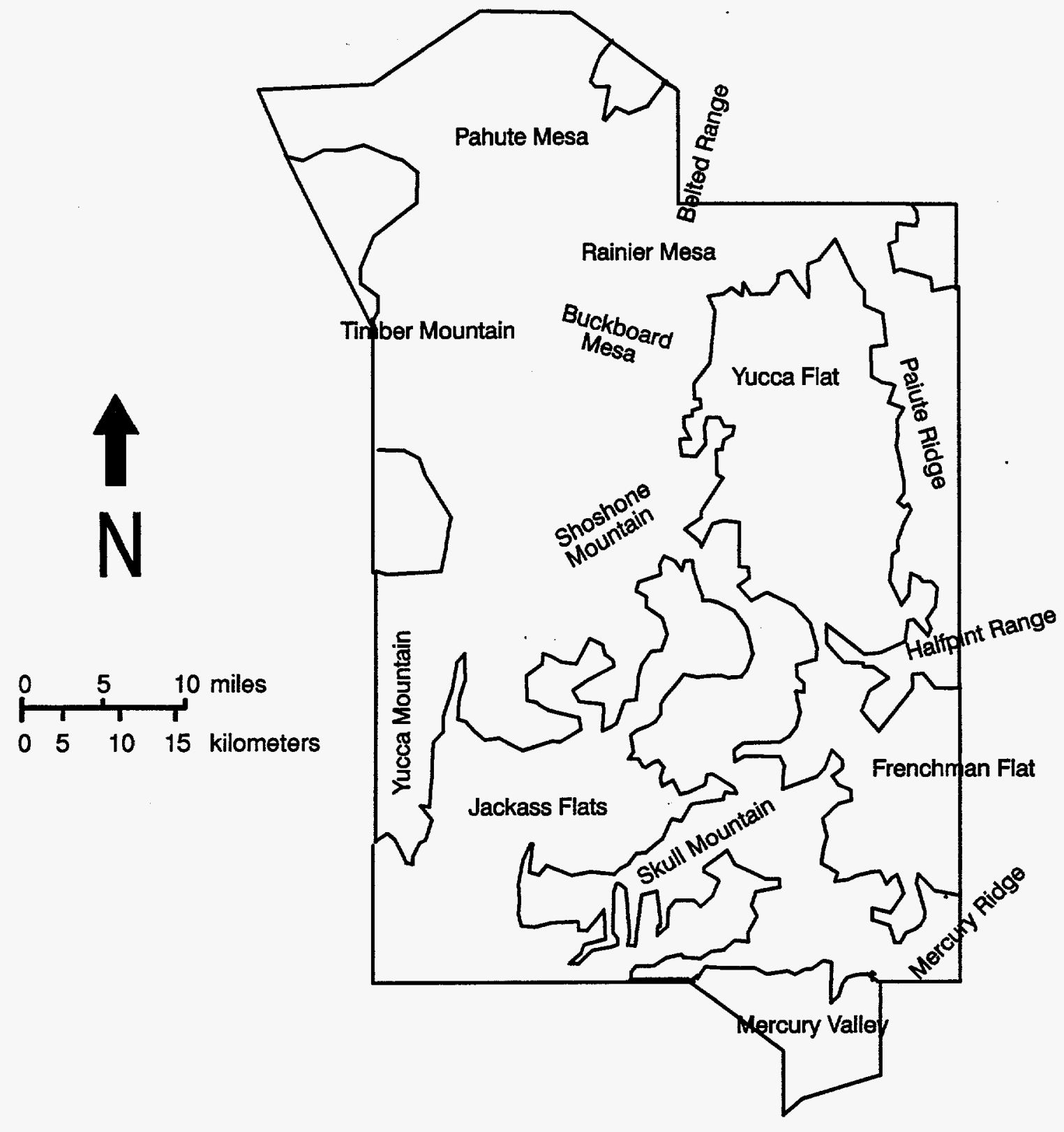

Figure 1. Physiographic features at the Nevada Test Site.

sedimentary rocks have undergone several deformational events, resulting in a series of north-south-oriented thrust faults associated with complex folding and normal faulting. The volcanic rocks of Tertiary age are predominantly rhyolitic tuffs ejected from the Silent Canyon and Timber Mountain calderas, located in the northwest portion of the NTS (Figure 2). The aggregate thickness of these volcanic rocks is several thousand meters; however, extremely variable thickness of individual sections result from erosion and non-deposition. Tertiary rocks are deformed much less than the Paleozoic rocks. Tertiary rocks are down-dropped in the valleys and tilted along steeply dipping late Tertiary faults. Alluvial sediments are composed of Paleozoic and Tertiary rock fragments, and fill the valleys to a maximum thickness of 600 to 900 meters. Alluvial sediments 


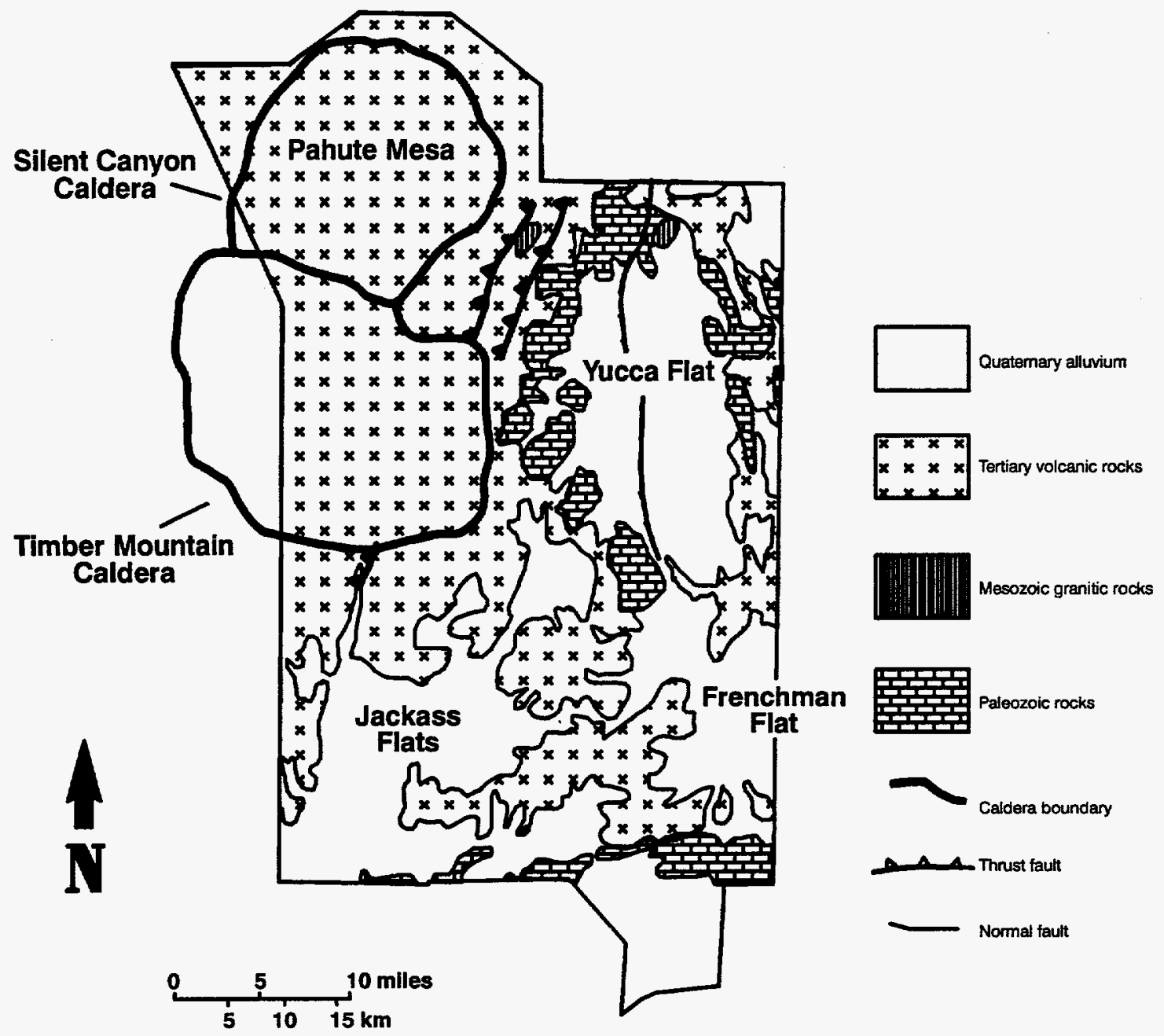

Figure 2. Major rock types at the Nevada Test Site.

appear to be relatively undeformed except for offsets formed by recent faulting as seen along the north-south-trending Yucca Fault in central Yucca Flat.

Table 1 presents a hydrostratigraphic classification of the principal lithologic units at the NTS as modified from Winograd and Thordarson (1975). This hydrostratigraphic classification applies specifically to Yucca Flat, the only area where the areal extent of saturated hydrostratigraphic units have been defined (Winograd and Thordarson, 1975); however, generalizations can be extended to other portions of the NTS. The unconsolidated valley-fill aquifers transmit groundwater via intergranular primary porosity interstices. Tertiary volcanic aquifers consist of lava flows, welded tuffs, and bedded tuffs, and Tertiary volcanic aquitards consist of non-welded zeolitized tuffs. In general, groundwater flow in Tertiary volcanic aquifers occurs in Paleozoic upper and lower carbonate aquifers consist of fractured carbonate rocks and Paleozoic clastic aquitards consist of interbedded clastic shales and quartzites. 
TABLE 1. HYDROSTRATIGRAPHIC CLASSIFICATION OF PRINCIPAL LITHOLOGIC UNITS AT THE NEVADA TEST SITE.

\begin{tabular}{|c|c|c|}
\hline Geologic Time Period & Stratigraphic Unit & Hydrogeologic Unit \\
\hline \multirow[t]{6}{*}{ Cenozoic } & Valley Fill & Valley-Fill Aquifer \\
\hline & $\begin{array}{l}\text { Basalt of Kiwi Mesa } \\
\text { Rhyolite of Shoshone Mountain } \\
\text { Basalt of Skull Mountain }\end{array}$ & Lava-Flow Aquifer \\
\hline & $\begin{array}{l}\text { Timber Mountain Tuff } \\
\text { Paintbrush Tuff }\end{array}$ & Welded Tuff Aquifer \\
\hline & Informal Bedded Tuff & Bedded Tuff Aquifer \\
\hline & Wahmonie Formation & $\begin{array}{l}\text { Lava-Flow Aquitard/ } \\
\text { Tuff Aquitard }\end{array}$ \\
\hline & $\begin{array}{l}\text { Salyer Formation } \\
\text { Belted Range Tuff } \\
\text { Local Informal Units } \\
\text { Rhyolite Flows and Tuffaceous } \\
\text { Beds of Calico Hills } \\
\text { Tuff of Crater Flat } \\
\text { Lithic Ridge Tuff } \\
\text { Rocks of Pavits Spring } \\
\text { Horse Spring Formation }\end{array}$ & Tuff Aquitard \\
\hline Mesozoic & Granitic Stocks & Minor Aquitard \\
\hline \multirow[t]{3}{*}{ Paleozoic } & Tippipah Limestone & Upper Carbonate Aquifer \\
\hline & Eleana Formation & Upper Clastic Aquitard \\
\hline & $\begin{array}{l}\text { Devil's Gate Limestone } \\
\text { Nevada Formation } \\
\text { Undifferentiated Dolomite } \\
\text { Ely Springs Dolomite } \\
\text { Eureka Quartzite } \\
\text { Pogonip Group } \\
\text { Nopah Formation } \\
\text { Bonanza King Formation } \\
\text { Carrera Formation }\end{array}$ & Lower Carbonate Aquifer \\
\hline Precambrian & $\begin{array}{l}\text { Zabriskie Quartzite } \\
\text { Wood Canyon Formation } \\
\text { Stirling Quartzite } \\
\text { Johnnie Formation }\end{array}$ & Lower Clastic Aquitard \\
\hline
\end{tabular}

The NTS has been divided into three hydrographic subbasins (Figure 3), all considered part of the larger Death Valley groundwater basin (Waddell et al., 1984). Groundwater within the Ash Meadows subbasin flows from areas north and east of the NTS, southwestward toward springs at Ash Meadows (Winograd and Thordarson, 1975). Groundwater within this subbasin is thought to flow primarily in the lower carbonate aquifer. The distribution of hydraulic heads and the direction 

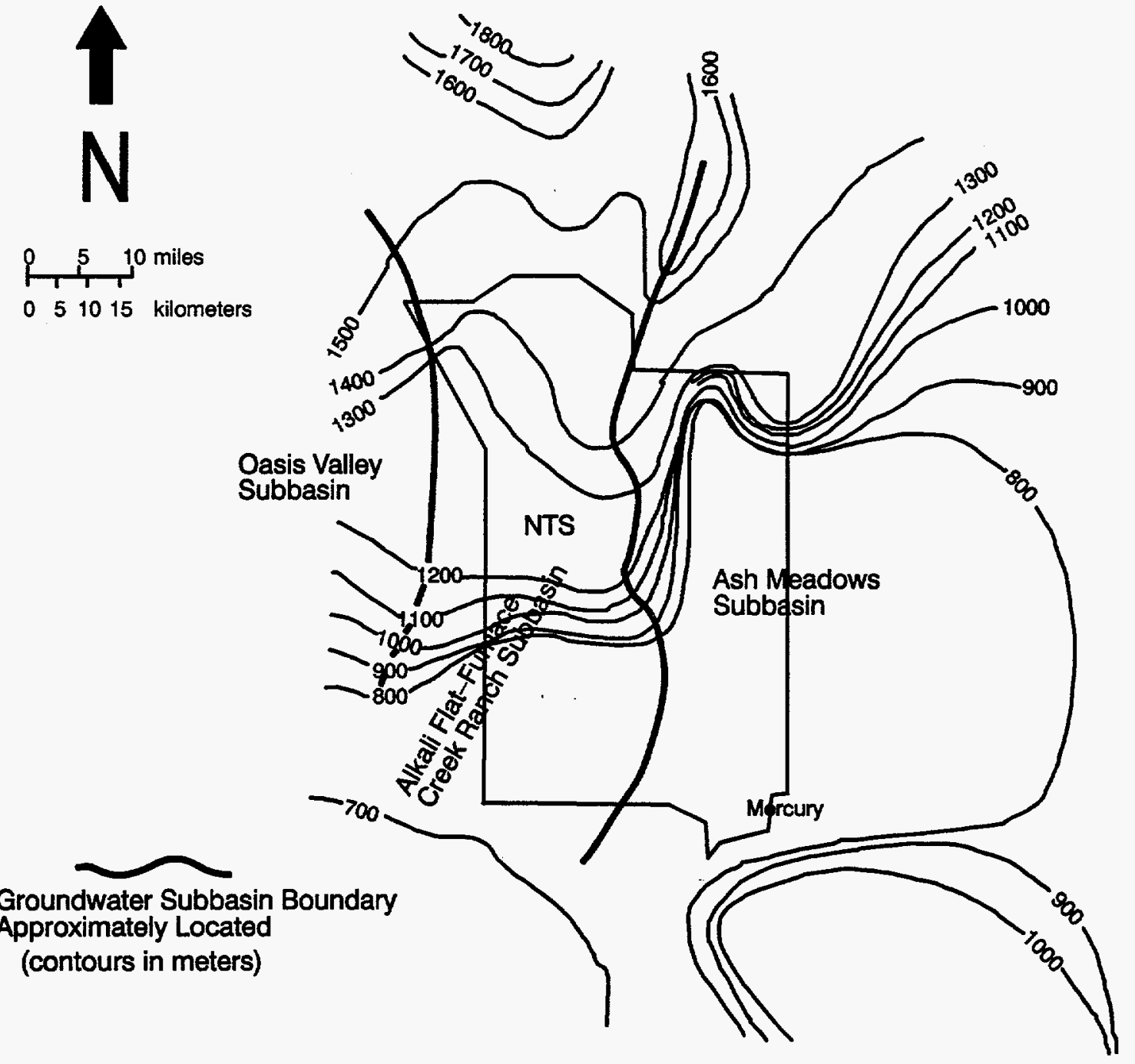

Figure 3. Composite potentiometric surface and hydrographic subbasins at the Nevada Test Site (after Waddell et al., 1984).

of flow within the subbasin are greatly affected by the presence of low permeability rocks of the lower clastic aquitard (Winograd and Thordarson, 1975). Groundwater from the majority of the western portion of the NTS flows from Pahute Mesa (and possibly other northern areas), southward toward Alkali Flat in the central Amargosa Desert. Groundwater flows through the valley-fill, volcanic, and lower carbonate aquifers. Groundwater discharges at Alkali Flat by evapotranspiration with possibly some groundwater underflow continuing to Death Valley (Winograd and Thordarson, 1975). The remaining portion of groundwater from western Pahute Mesa and areas further north is thought to flow southward, through the western portion of the NTS, within the Oasis Valley subbasin. Groundwater from this flow system discharges primarily by evapotranspiration at Oasis Valley and with underflow to the Alkali Flat-Furnace Creek Ranch subbasin (White, 1979). Groundwater in Pahute Mesa flows primarily through interbedded volcanic 
rocks with extreme vertical and horizontal hydraulic conductivity contrasts (Blankennagel and Weir, 1973). The boundaries of the subbasins are poorly defined and have been placed at different locations by different authors. Data are sparse; the average density of wells at the NTS is less than 0.05 per square kilometer (excluding device emplacement and post-shot holes. The paucity of wells inhibit the determination of vital hydrologic information that is needed to develop detailed local scale flow models. Hydrologic characteristics such as the rate and direction of interaquifer flux, the perturbations created by localized geologic structures and nuclear testing, and the delineation of permeable and impermeable zones within individual hydrologic units have not been adequately determined.

The interpretation of groundwater chemical analyses has been extremely valuable in further developing conceptual models of regional groundwater flow. Schoff and Moore (1964) performed the first comprehensive study of the chemical quality of NTS groundwater. They classified groundwater at the NTS into three broad categories: a sodium and potassium bicarbonate type; a calcium and magnesium bicarbonate type; and, a mixed type consisting of the first two in varying proportions. The sodium and potassium bicarbonate type is found in the tuff aquifers and aquitards. The calcium and magnesium bicarbonate type is found in Paleozoic carbonate aquifers and valley-fill aquifers that are composed primarily of carbonate rock detritus. Mixed type waters are found throughout the NTS and are thought to form in several ways: by movement of sodium and potassium bicarbonate type water from tuffaceous rocks into carbonate rocks or alluvium; by movement of calcium and magnesium bicarbonate type water from carbonates into tuffaceous rocks; or, by mixing. Chapman and Lyles (1993) examined groundwater chemical analyses from 81 wells collected from 1957 to 1990 . They verified the existence of Schoff and Moore's three basic groundwater quality categories or types (also called hydrochemical facies). Chapman and Lyles also suggested a dominance of vertical flow within basins between the overlying volcanic aquifers and the underlying carbonate aquifers.

\section{POTENTIAL GROUNDWATER CONTAMINATION SOURCES}

A preliminary assessment of underground and surface contamination at the NTS was conducted by the DOE's Environmental, Safety, and Health Office of Environmental Audit in 1987 (U.S. DOE, 1988). The assessment delineated known and potential sources of groundwater contamination including underground testing sites and surface facilities. Because of the great depth to groundwater (from 112 meters at UE-16f to 672 meters at U-20be; Wood, 1992) and the arid climate at the NTS, it is assumed that the potential for mobilization of surface and shallow subsurface contamination is minimal. Therefore, the main source of possible groundwater contamination considered for this report is from underground nuclear testing. To date, there have been 828 underground nuclear tests conducted in five general locations at the NTS (U.S. DOE, 1993b). The principal by-products from nuclear testing are heavy metals (Bryant and Fabryka-Martin, 1991) and a wide variety of radionuclides with differing half-lives and decay products. Underground testing locations are identified on Figure 4 as shaded circles of 1000 meter radius around individual underground test sites. These shaded circles are located primarily in Yucca Flat, Frenchman Flat, Rainier Mesa, Pahute Mesa, and Shoshone Mountain. The majority of underground testing has been 


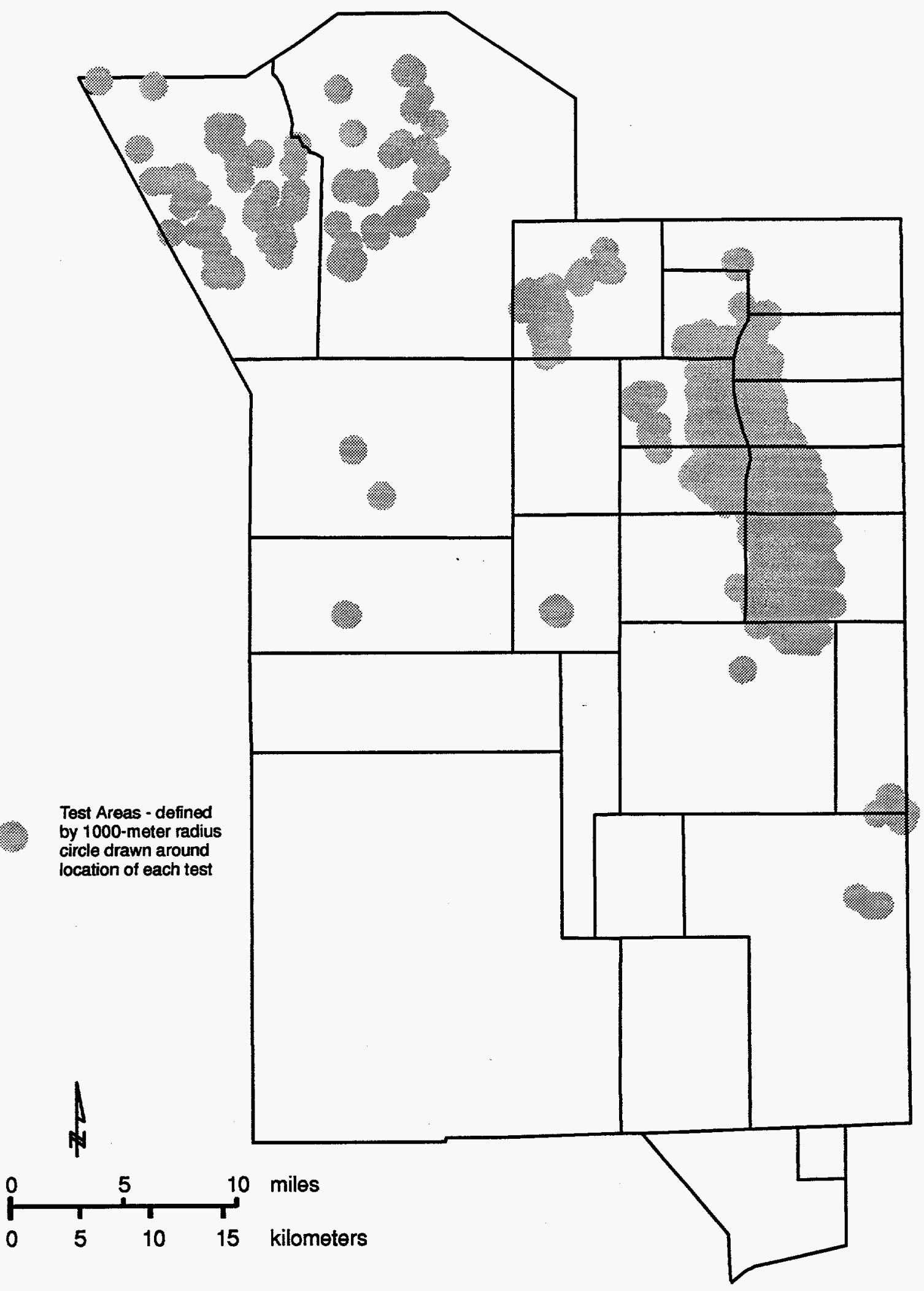

Figure 4. Underground nuclear testing locations at the Nevada Test Site. 
conducted in unsaturated alluvium and Tertiary volcanic rocks. However, some tests have been conducted below or near the groundwater table. Marsh (1992) listed approximately 150 tests from June 1957 through August 1988 that were detonated below or within 25 meters of the groundwater table (Appendix A).

\section{EXISTING GROUNDWATER MONITORING ACTIVITIES}

Regulatory and DOE Order driven groundwater monitoring at the NTS is conducted by Reynolds Electrical \& Engineering Co., Inc. (REECo) and the U.S. Environmental Protection Agency's (EPA) Environmental Monitoring Systems Laboratory in Las Vegas, Nevada (EMSL-LV). Groundwater monitoring for site characterization is also conducted at the NTS by the HRMP participants, the Underground Test Area Remedial Investigation and Feasibility Study (UGTA/RIFS) contractors, and the Area 5 Radioactive Waste Management Site (RWMS) contractors. Existing groundwater monitoring activities at the NTS are described below.

\section{REECo's Environmental Monitoring Program}

REECo's on-site radiological surveillance network includes seven springs, nine potable water-supply wells, four non-potable water-supply wells, and nine drinking-water consumption points (U.S. DOE, 1993a). In 1992, water from on-site groundwater supply wells (Figure 5) was sampled and analyzed for radiological substances according to the schedule presented in Table 2. Radiological analyses are conducted by REECo. Non-radiological drinking-water sampling is also conducted; however, analyses are performed by off-site contract laboratories.

Monthly samples are collected from seven springs and analyzed for gamma activity, gross beta activity, and tritium activity (conventional method). Quarterly spring samples are collected and analyzed for ${ }^{238} \mathrm{Plutonium}$ and $239+240 \mathrm{Plutonium}$. Annual spring samples are collected and analyzed for ${ }^{90}$ Strontium. Springs are not used for human drinking-water supply at the NTS but are a source of water for feral birds and animals.

Monthly groundwater samples are collected from nine potable water-supply wells and analyzed for gamma activity, gross beta activity, and tritium activity (conventional method). Quarterly samples of groundwater are collected and analyzed for ${ }^{238}$ Plutonium, ${ }^{239+240}$ Plutonium, gross alpha activity, ${ }^{226}$ Radium, ${ }^{228}$ Radium, and tritium activity (enrichment method). Annual groundwater samples are collected and analyzed for ${ }^{90}$ Strontium.

Monthly groundwater samples are collected from four non-potable water-supply wells and analyzed for gamma activity, gross beta activity, and tritium activity (conventional method). Quarterly samples of groundwater are collected and analyzed for ${ }^{238}$ Plutonium and $239+240$ Plutonium. Annual groundwater samples are collected and analyzed for ${ }^{90}$ Strontium.

The NTS has five drinking-water supply systems that are fed by the nine potable supply wells (Table 3). Weekly drinking-water samples are collected from nine consumption points distributed between the five water-supply systems, and are collected from bottled water supplied by a Las Vegas vendor to Area 6. These weekly drinking-water samples are analyzed for gamma activity, gross beta 


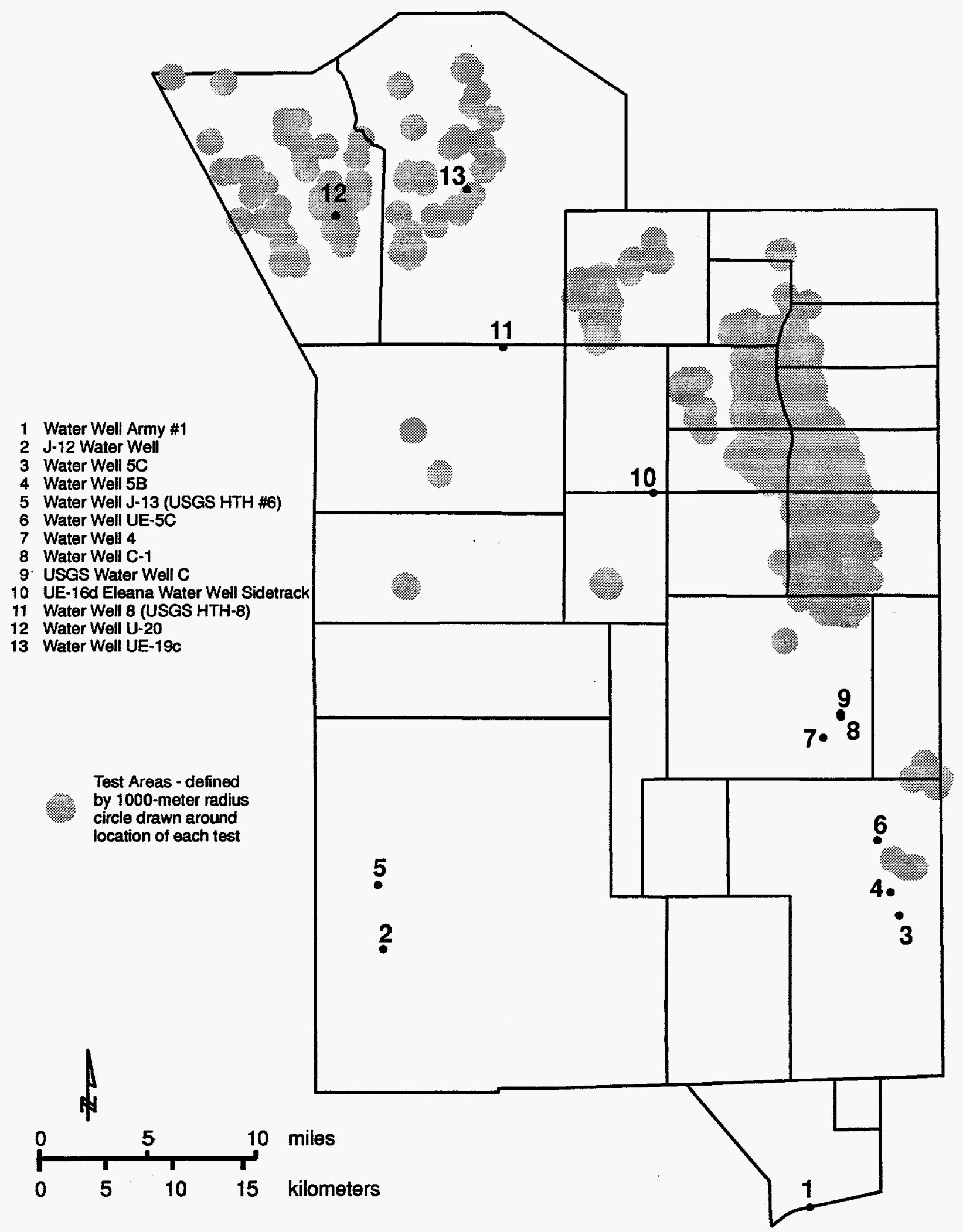

Figure 5. Groundwater supply wells sampled in 1992 by REECo's Environmental Monitoring Program at the Nevada Test Site. 
activity, and tritium activity. Quarterly drinking-water samples are collected from consumption points and bottled water, and are analyzed for gross alpha activity, ${ }^{238}$ Plutonium, and 239+240Plutonium.

TABLE 2. REECO'S 1992 ENVIRONMENTAL MONITORING PROGRAM SAMPLING SCHEDULE OF POTABLE AND NON-POTABLE WATER-SUPPLY WELLS AND SPRINGS AT THE NEVADA TEST SITE.

\begin{tabular}{|c|c|c|c|c|}
\hline Area & Sample Location & Radiological & Nonradiological & Comments \\
\hline 5 & Water Well 5C & $a, b, c$ & d & \\
\hline 5 & Water Well UE-5C & a,c,e & & \\
\hline 5 & Water Well 5B & $a, c, e$ & & Well shut down (U.S. DOE, 1992) \\
\hline 5 & Cane Spring & $\mathrm{a}, \mathrm{c}, \mathrm{e}$ & & \\
\hline 6 & Water Well 4 & $a, b, c$ & d & \\
\hline 6 & USGS Water Well C & $a, b, c$ & d & \\
\hline 6 & Water Well C-1 & $a, b, c$ & d & \\
\hline 7 & Reitmann Seep & $a, c, e$ & & \\
\hline 12 & Captain Jack Spring & $\mathrm{a}, \mathrm{c}, \mathrm{e}$ & . & \\
\hline 12 & Gold Meadows & $\mathrm{a}, \mathrm{c}, \mathrm{e}$ & & \\
\hline 12 & White Rock Spring & $\mathrm{a}, \mathrm{c}, \mathrm{e}$ & & \\
\hline 15 & Water Well UE-15d & $a, b, c$ & d & Well no longer operated (U.S. DOE, 1993) \\
\hline 16 & Tippipah Spring & $\mathrm{a}, \mathrm{c}, \mathrm{e}$ & & \\
\hline 18 & Water Well 8 & $a, b, c$ & d & \\
\hline 19 & Water Well UE-19c & $a, c, e$ & & \\
\hline 20 & Water Well U-20 & $\mathrm{a}, \mathrm{c}, \mathrm{e}$ & & \\
\hline 22 & Water Well Army \#1 & $a, b, c$ & d & \\
\hline 25 & J-12 Water Well & $a, b, c$ & d & \\
\hline 25 & Water Well J-13 & $a, b, c$ & d & \\
\hline 29 & Topopah Spring & $a, c, e$ & & \\
\hline $\begin{array}{r}\text { Samp } \\
\text { a. } \mathrm{M} \\
* 1 \\
* \mathrm{C} \\
* \mathrm{C} \\
\text { b. } \mathrm{Q} \\
* \mathrm{C} \\
*_{\mathrm{I}} \\
*_{1} \\
*^{r}\end{array}$ & $\begin{array}{l}\text { ling Schedule } \\
\text { onthly } \\
\text { ritium Activity, conve } \\
\text { Jross Beta Activity } \\
\text { Jamma Activity } \\
\text { larterly } \\
\text { Sross Alpha Activity } \\
\text { lutonium } 238,239+2 \\
\text { Cadium } 226,228 \\
\text { ritium Activity, enrich }\end{array}$ & onal & & $\begin{array}{l}\text { c. Annually } \\
\text { *Strontium } 90 \\
\text { d. Annually } \\
\text { *Volatile Organic Compounds } \\
\text { *Inorganics \& Metals } \\
\text { e. Quarterly } \\
\text { *Plutonium } 238,239,+240\end{array}$ \\
\hline
\end{tabular}


TABLE 3. 1992 WATER-SUPPLY WELLS, POPULATION, AND COMMUNITY/ NONCOMMUNITY STATUS OF PUBLIC DRINKING WATER SYSTEMS AT THE NEVADA TEST SITE.

\begin{tabular}{lllll}
\hline \hline Permit No. & Area(s) & Population & Status & Water Wells \\
\hline $360-12 \mathrm{C}$ & 22,23 & 1500 & Community & 5C, Army \#1 \\
$4097-12 \mathrm{NC}^{1}$ & 3 & 200 & Noncommunity & C, C-1, 4 (hauled water) \\
$5000-12 \mathrm{NC}$ & 6,27 & 1000 & Noncommunity & C, C-1, 4 \\
$4098-12 \mathrm{NC}$ & 25 & 200 & Noncommunity & J12, J13 \\
$4099-12 \mathrm{C}$ & 2,12 & 1000 & Community & 8 \\
$5024-12 \mathrm{NC}$ & 1 & 200 & Noncommunity & UE-16d Eleana
\end{tabular}

${ }^{1}$ This permit has been allowed to expire as personnel in the Area 3 camp have been relocated to Area 6.

Non-radiological monitoring of drinking water is also conducted by REECo at the NTS. All NTS drinking-water distribution systems are sampled monthly at various consumption points for coliform bacteria. Samples are sent off-site for analysis. Monthly residual chlorine using colorimetric methods and $\mathrm{pH}$ measurements are made at drinking-water consumption points. Annual drinking-water samples are collected from consumption points and analyzed for inorganic constituents and water-quality parameters. Samples are sent off-site for analysis. Annual groundwater samples are collected from potable water-supply wells and analyzed for volatile organic compounds. Samples are sent off-site for analysis. Occasionally, the State of Nevada will collect and analyze groundwater samples from NTS potable water-supply wells for inorganic constituents. In 1992, the State of Nevada collected and analyzed groundwater from Water Well 4A.

\section{EMSL-LV's Long-Term Hydrologic Monitoring Program}

The EMSL-LV conducts the Long-Term Hydrologic Monitoring Program (LTHMP). The LTHMP is a radiological groundwater monitoring network on and around the NTS, and at other U.S. locations where nuclear weapons tests have been conducted (U.S. DOE, 1993a). This discussion is limited to the on-site and NTS vicinity network. In 1992, groundwater from wells shown in Figure 6 was sampled for radiological substances according to the schedule presented in Table 4.

In 1992, monthly groundwater samples were collected from 14 wells and biannual samples were collected from 17 others. All samples are analyzed for gamma and tritium activity. All samples are analyzed using the conventional tritium method. When sample results are close to the minimum detectable concentration (MDC) of the method ( 400 to $700 \mathrm{pCi} / \mathrm{L})$, the sample is re-analyzed using the tritium enrichment method (MDC of 5 to $7 \mathrm{pCi} / \mathrm{L}$ ). Tritium analysis of biannual samples is alternated between the conventional method and the enrichment method from one sample to the next. Three springs (Crystal Pool, Fairbanks Springs, and Spring 17S-50E-14cac) and one well (Well 18s-51E-7db) located in Ash Meadows are sampled monthly and analyzed for gamma activity and are also sampled biannually for tritium activity. When a new sampling location is added to the network, first time samples are collected and analyzed for ${ }^{238}$ Plutonium, ${ }^{239+240}$ Plutonium, ${ }^{89}$ Strontium, ${ }^{90}$ Strontium, and uranium isotopes. 


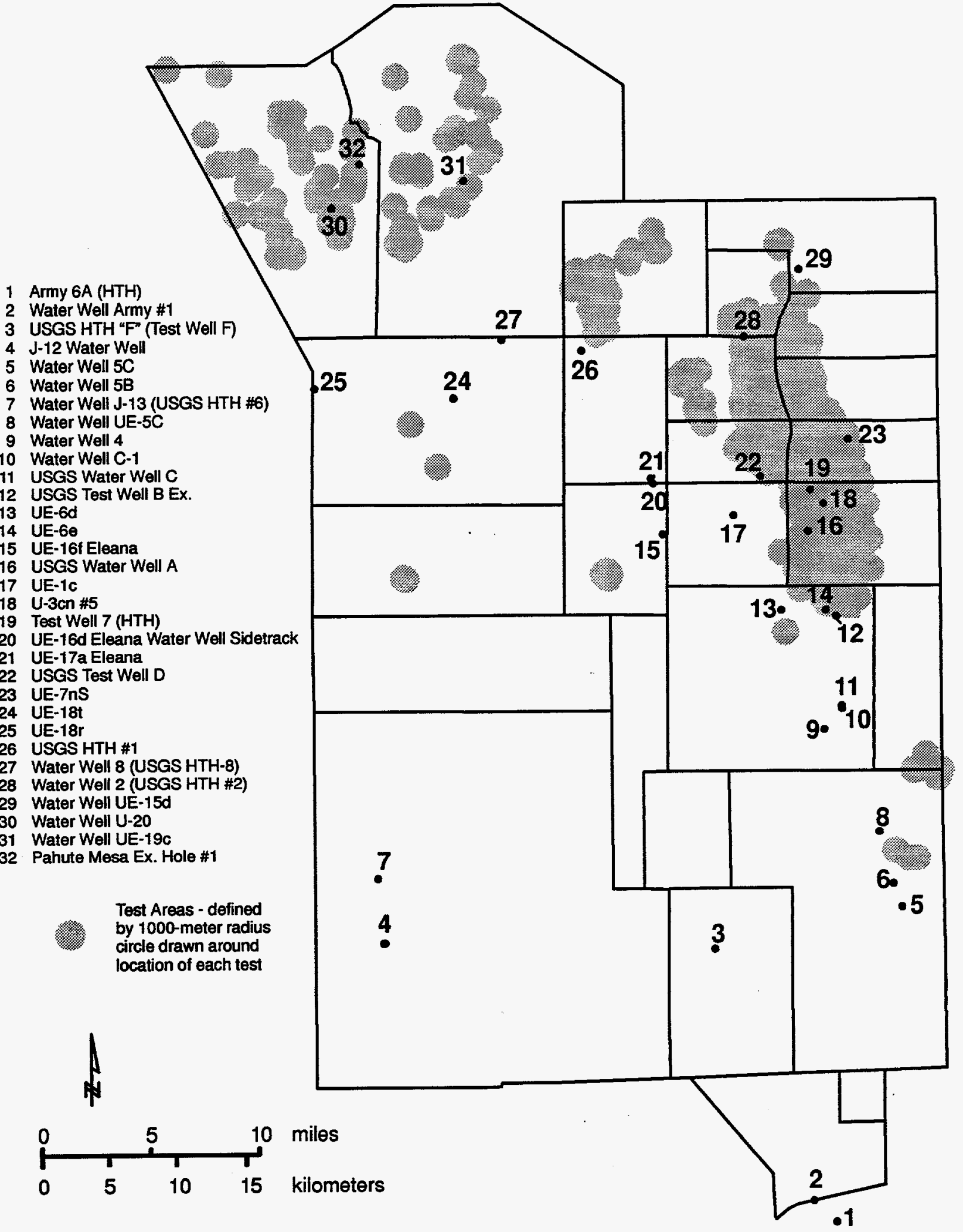

Figure 6. Groundwater wells sampled in 1992 by EMSL-LV at the Nevada Test Site. 
TABLE 4. EMSL-LV'S 1992 LTHMP SAMPLING SCHEDULE OF WELLS AT THE NEVADA TEST SITE.

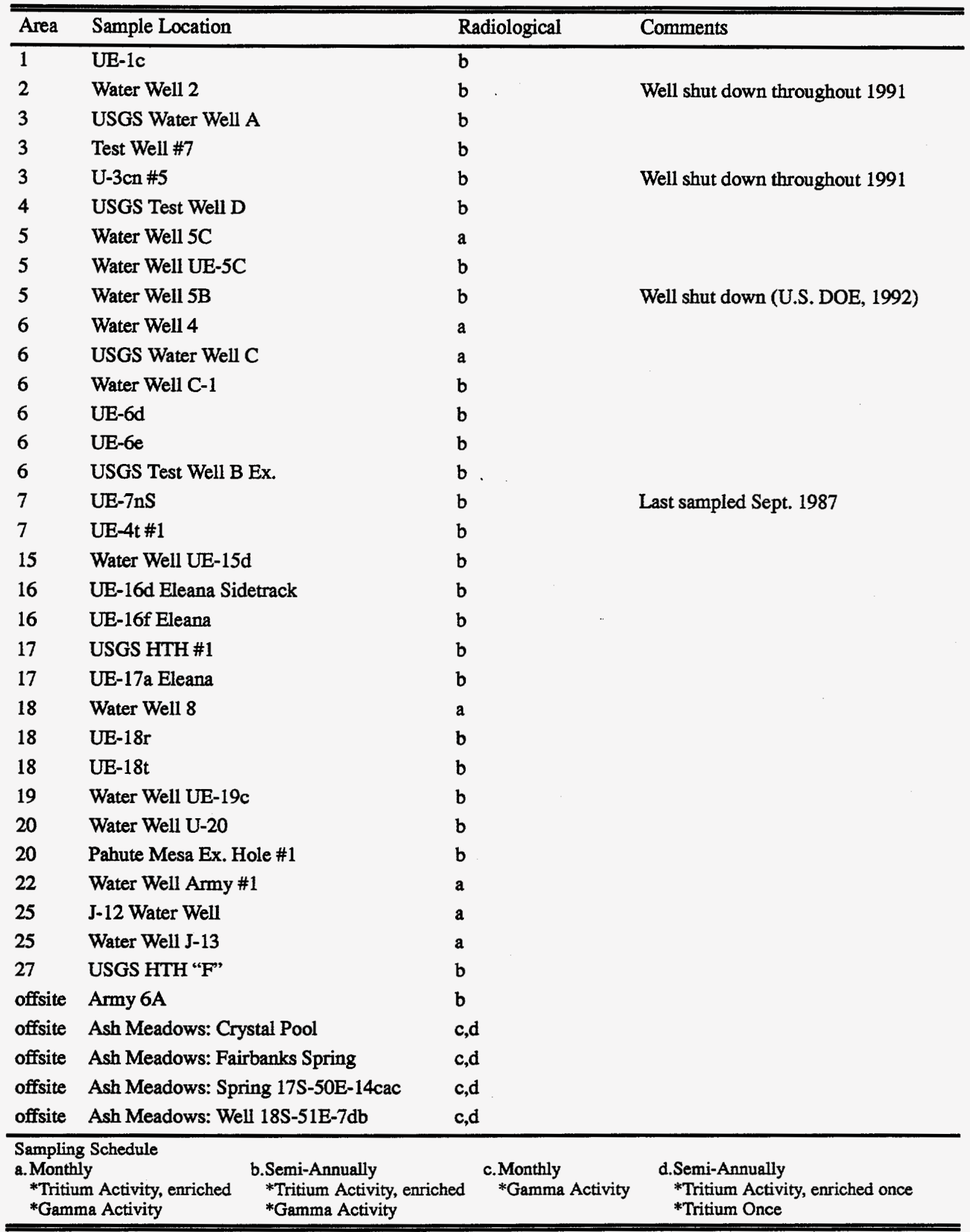




\section{U.S. Geological Survey's Water-level Monitoring Program}

The U.S. Geological Survey (USGS) in support of the HRMP collects and compiles hydrologic data to aid in characterizing the local and regional groundwater flow systems underlying the NTS (Wood, 1992). Depth-to-water measurements are made in approximately 72 wells and test holes at and in the vicinity of the NTS (Figure 7). Occasionally, groundwater samples are collected for tritium analysis. Samples are analyzed by EMSL-LV using the enrichment method.

Historical depth-to-water measurements are used to indicate long-term depth-to-water fluctuations and to provide a record of all reported completion depths or open intervals for associated wells and test holes. Measurements are obtained by either wire-line, steel-tape, or iron-horse methods. The network consists of short-term test holes and long-term observation wells and test holes. Depth to water is measured intermittently in all accessible test holes that penetrate the saturated zone. These measurements are made frequently until the measured depth to water stabilizes, or until the hole is destroyed or becomes inaccessible. The majority of test holes are short-term holes and the opportunity to measure depth to water is limited to a few weeks or a few months. Other observation wells and test holes are available for long-term depth-to-water measurements. Wells or test holes that exhibit minor fluctuations in depth to water are measured annually. Wells or test holes that exhibit large fluctuations in depth-to-water are measured weekly, quarterly, or continuously.

\section{Other Groundwater Sampling Programs}

Some non-routine groundwater sampling is conducted by HRMP participants to accomplish the program goals to protect groundwater, support NTS operations, and conduct long-range hydrologic investigations. Groundwater monitoring activities consist primarily of non-routine sampling for radiological and non-radiological constituents to answer specific hydrologic questions. UGTA/RIFS participants are drilling new wells to obtain information to characterize the hydrogeology on the NTS. That program's specific goal is to obtain data to support Comprehensive Environmental Response, Compensation and Liability Act (CERCLA) driven site characterization and risk assessment. Groundwater samples are collected from new wells for radiological and non-radiological analysis. Groundwater samples are also being collected to characterize the hydrogeology of the Area 5 RWMS as required for a Resource Conservation and Recovery Act (RCRA) Part B permit needed to operate the waste management facility.

\section{RATIONALE FOR SPECIFIC CONSTITUENT MONITORING}

Groundwater monitoring activities at the NTS are conducted for several reasons. These reasons include the detection of radioactive constituents produced by nuclear testing, monitoring to satisfy State of Nevada and federal regulatory requirements, and monitoring to satisfy DOE Order requirements.

\section{Detection of Radioactive Constituents}

Underground nuclear detonations produce radioactivity from three different sources: original device materials that have not undergone the fission or thermonuclear reaction (e.g., ${ }^{239}$ Plutonium), 


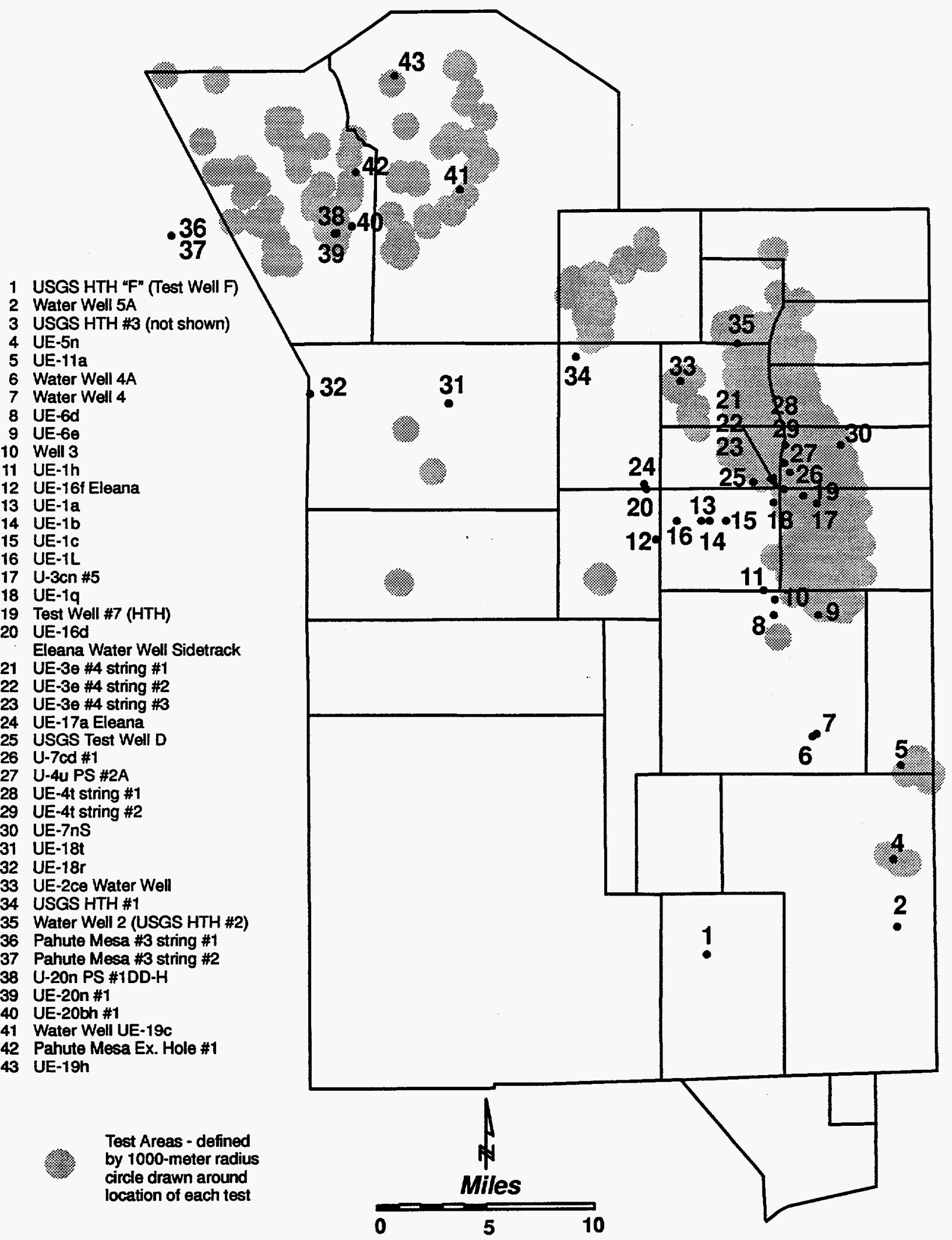

Figure 7. Groundwater wells where depth-to-water is measured by the USGS at the Nevada Test Site. 
nuclear reaction products (e.g., ${ }^{90}$ Strontium), and radionuclides produced from neutron activation (e.g., ${ }^{14}$ Carbon). As described in Borg et al. (1976), all device materials and much of the surrounding rock are vaporized at detonation and some of the resulting gaseous radionuclides are injected into fractures. As heat starts to dissipate, radionuclides separate according to their boiling points, the refractory or high boiling point radionuclides are concentrated in the solidifying puddle glass and the volatile or low boiling point radionuclides are distributed through the forming rubble chimney.

Radionuclides produced from detonations below, at, or near the water table begin to react with the groundwater. Chemical reactions between groundwater and radionuclides injected into fractures, incorporated in the puddle glass, or distributed in the chimney are poorly understood; however, limited research suggests that several processes are important when considering the mobility of radionuclides with groundwater. First, the rate of radioactive decay or the half-life of individual radionuclides is important. Many weapons-produced radionuclides have short half-lives resulting in a rapid decrease of concentration with time. Because groundwater at the NTS moves slowly, only radionuclides with half-lives of one year or more are considered significant (Borg, $e t$ al., 1976). Second, leaching or dissolution of radionuclides from puddle glass and the rubble chimney is important. These radionuclides become mobile in dissolved form and occur in both cationic and anionic forms. Third, cationic species tend to be less mobile in groundwater than anionic forms because of their greater tendency to sorb onto mineral surfaces. Generally, the most significant sorption process is some form of ion exchange (Borg et al., 1976). Fourth, radionuclides also sorb onto colloidal particles which can increase their mobility as the suspended particles move with groundwater. Fifth, electrostatically neutral species such as the radioactive gas ${ }^{85} \mathrm{Krypton}$ or water molecules with a tritium atom (HTO) are unaffected by the previously mentioned processes and will move with groundwater. Finally, concentrations of groundwater transported radionuclides are probably affected by dispersion which decreases concentrations with time. Table 5 lists long-lived radionuclides produced from nuclear testing that may be observable in groundwater at the NTS as described by Borg et al. (1976).

Present groundwater monitoring programs at the NTS as outlined above are best described as detection monitoring programs. Their primary function is to identify the presence of weapons-related radionuclides in groundwater. In almost every case, sampling locations are existing wells drilled for geologic or hydrologic exploration, nuclear device emplacement, post-shot evaluation, or water supply. None were specially designed, sited, and drilled to track weapons-related radionuclides in groundwater (Russell, 1991). Thus, groundwater monitoring locations at the NTS can best be described as points of opportunity. The present groundwater monitoring programs can only assure that weapons-related radionuclides are not found in groundwater at those points sampled. Because of the great depth to water, the large surface area, and the great expense of drilling, the possibility of drilling new wells to add to the present groundwater monitoring programs is limited. However, the UGTA/RIFS is presently drilling wells for site groundwater characterization. In the future, that program will drill wells to identify underground nuclear testing source terms, quantifying those source terms, and will also drill wells specifically designed to track radionuclides in groundwater at the NTS. 


\begin{tabular}{|c|c|c|}
\hline Nuclide & Half-Life (years) & Source \\
\hline 235 Uranium & $7.1 \times 10^{8}$ & Device Material \\
\hline${ }^{99}$ Technetium & $2.1 \times 10^{5}$ & Nuclear Reaction \\
\hline${ }^{239}$ Plutonium & $2.4 \times 10^{4}$ & Device Material \\
\hline${ }^{14}$ Carbon & 5730 & Neutron Activation \\
\hline${ }^{39}$ Argon & 270 & Neutron Activation \\
\hline${ }^{151}$ Samarium & 87 & Nuclear Reaction \\
\hline${ }^{137}$ Cesium & 30 & Nuclear Reaction \\
\hline${ }^{90}$ Strontium & 28 & Nuclear Reaction \\
\hline${ }^{3}$ Hydrogen & 12.3 & Neutron Activation \\
\hline${ }^{152}$ Europium & 12 & Neutron Activation \\
\hline${ }^{85}$ Krypton & 10.8 & Nuclear Reaction \\
\hline${ }^{60}$ Cobalt & 5.3 & Neutron Activation \\
\hline${ }^{125}$ Antimony & 2.7 & Nuclear Reaction \\
\hline 147Promethium & 2.6 & Nuclear Reaction \\
\hline${ }^{55}$ Iron & 2.6 & Neutron Activation \\
\hline${ }^{134}$ Cesium & 2 & Neutron Activation \\
\hline${ }^{155}$ Europium & 1.8 & Nuclear Reaction \\
\hline${ }^{106}$ Ruthenium & 1 & Nuclear Reaction \\
\hline
\end{tabular}

\section{Regulatory Requirements}

Compliance groundwater monitoring at the NTS is conducted to satisfy both State of Nevada and federal regulatory requirements. State and federal regulations include the Safe Drinking Water Act (SDWA), CERCLA, and RCRA. A brief description of pertinent portions of these regulations are listed below.

\section{Safe Drinking Water Act}

The SDWA is a federal and State of Nevada regulation that is administered by the Health Division of Nevada's Department of Human Resources. The regulation sets water-quality standards for public water-supply systems. Descriptions of the regulation pertaining to the groundwater monitoring programs at the NTS are listed below. Copies of SDWA regulations sited below are included in Appendix B.

Nevada Revised Statute (NRS). Chapter 445.361 to 445.399 outlines the basic legal requirements of public water systems. It is the policy of the state to provide water that is safe for drinking and other domestic purposes (NRS 445.361). A public water system is defined as any system that provides the public with piped water for human consumption and serves 25 or more people for 60 days or more per year (NRS 445.376). The state board of health is required to adopt 
by regulation the primary and secondary drinking-water standards established by the Federal SDWA (NRS 445.379).

Nevada Administrative Code (NAC). Chapter 445.244 to 445.262 describes the water-quality requirements of public water systems. All public water systems must meet the primary standards of the National Primary Drinking Water regulations listed in 40 Code of Federal Regulations (CFR) chapters $141.1,141.4,141.5,141.11$ to 141.16 inclusive, 141.61, 141.62, 141.63, 141.100, 141.101, 141.110, and 141.111 (NAC 445.247). Monitoring and analytical requirements for primary standards must be performed as required in 40 CFR chapter 141.21 to 141.30 inclusive, and 141.40 to 141.42 inclusive (NAC 445.2475). Secondary standards must also be met and are listed in NAC 445.248. Monitoring requirements for secondary standards are listed in NAC 445.249. Analysis methods for secondary standards are listed in NAC 445.250.

Sampling Frequency Requirements, National Primary Drinking Water Regulations. 40 CFR 141.2 defines the monitoring compliance cycle as the nine-year calendar-year cycle where public water systems must monitor. The first calendar-year cycle begins January 1, 1993 and ends December 31, 2001. A compliance cycle is divided into three compliance periods of three years each. Constituents required to be analyzed during the compliance periods are listed below.

- Coliform (40 CFR 141.21): monitoring frequency for total coliform for community water systems is based on population served.

- Turbidity (40 CFR 141.22): required for systems using surface-water sources in whole or in part (40 CFR 141.13).

- Inorganic chemicals (40 CFR 141.23): community water systems utilizing only groundwater sources will have analyses completed within two years of effective date of 40 CFR 141.23. Analyses must be repeated at three-year intervals.

- Organic chemicals other than total trihalomethanes (40 CFR 141.24): community water systems utilizing only groundwater sources will have analyses completed as specified by the state.

- Radioactivity (40 CFR 141.26 (a)): initial sampling for gross alpha particle activity, ${ }^{226}$ Radium and ${ }^{228}$ Radium to determine compliance will begin within two years of the effective date of 40 CFR 141.26. Compliance will be based on the analysis of an annual composite of four consecutive quarterly samples or the average of the analyses of four samples obtained at quarterly intervals. Continued monitoring will be conducted at least once every four years following the initial analysis. A gross alpha particle activity measurement may be substituted for the required ${ }^{226}$ Radium and ${ }^{228}$ Radium analyses provided the gross alpha activity does not exceed five picocurries per liter (pCi/L). When gross alpha activity exceeds five $\mathrm{pCi} / \mathrm{L}$, a sample will be analyzed for ${ }^{226}$ Radium. If the ${ }^{226}$ Radium concentration exceeds three $\mathrm{pCi} / \mathrm{L}$, a sample will be analyzed for ${ }^{228}$ Radium.

- Radioactivity (40 CFR 141.26 (b)): sampling for man-made radioactivity in community water systems using surface-water sources and serving more than 100,000 persons, or 
systems designated by the state, is required within two years of the effective date of 40 CFR 141.26. Compliance will be based on the analysis of a composite of four consecutive quarterly samples or analysis of four quarterly samples. At the discretion of the state, suppliers of water utilizing only groundwaters may be required to monitor for manmade radioactivity. After initial analysis, suppliers will monitor at least every four years. Any community water system designated by the state as utilizing waters contaminated by effluents from nuclear facilities will initiate quarterly monitoring for gross beta particle and ${ }^{131}$ Iodine radioactivity, and annual monitoring for ${ }^{90}$ Strontium and tritium. Quarterly monitoring for gross beta particle activity will be based on the analysis of monthly samples or the analysis of a composite of three monthly samples. If the gross beta activity in a sample exceeds $15 \mathrm{pCi} / \mathrm{L}$, a sample will be analyzed for ${ }^{89}$ Strontium and ${ }^{134} \mathrm{Cesium}$. If the gross beta activity exceeds $50 \mathrm{pCi} / \mathrm{L}$, an analysis will be performed to identify the major radioactive constituents present and the appropriate organ and total body doses will be calculated to determine compliance. For ${ }^{131}$ Iodine, a composite of five consecutive daily samples will be analyzed once each quarter. Annual analysis of ${ }^{90}$ Strontium and tritium will be conducted on a composite of four consecutive quarterly samples or on four quarterly samples.

- Total trihalomethanes ( 40 CFR 141.30 ): community water systems that serve a population of 10,000 or more individuals and that add a disinfectant to the water will analyze for total trihalomethanes.

Sampling Frequency Requirements, Nevada Secondary Standards. Secondary standards (NAC 445.249): analysis of all public water systems must be completed by June 24, 1979, and repeated at three-year intervals or less as required by the health authority.

\section{Comprehensive Environmental Response, Compensation and Liability Act}

CERCLA was enacted by Congress to clean up hazardous waste sites for which responsible parties might not be readily known, or if known, be unwilling to participate in the cleanup. EPA is the lead agency and main regulatory body implementing CERCLA. The procedures and protocols for conducting investigations and remediation under CERCLA are found in the National Contingency Plan (NCP) which is a guidance document that prescribes a general methodology for conducting the investigations and selection of mitigation alternatives. Once a hazardous waste site is identified, a preliminary site assessment is made in which general information and the risks of the site are evaluated. Then the site is ranked for inclusion on the National Priority List (NPL), and, if the site receives a high enough score, it will be placed on the NPL and in the CERCLA "Superfund" program. Once a site has been ranked and placed on the NPL, a priority is assigned, and a time frame for site investigation is developed. Given the restricted staff and financial resources of EPA, only a limited number of sites are investigated at any one point in time (Executive Enterprises, Inc., 1991).

The procedures put forth in the NCP are called the remedial investigation and feasibility study (RI/FS). The RI/FS process calls for scoping and site-planning activities which include; the development of a site-specific work plan that details the procedures, scope of work, schedule, and 
analytical plan to conduct the investigation; a quality assurance project plan; a health and safety plan; and a data management plan. Upon completion of the planning, the actual remedial investigation is conducted to define the nature, extent, and magnitude of the problem. Following the remedial investigation, a risk assessment is conducted to evaluate and assess the potential public health and environmental impacts that the site may pose. The results of the remedial investigation and risk assessment are then combined to develop remedial action objectives. Remedial action objectives are generally health-based clean-up criteria and are developed for each affected environmental medium. Next, the feasibility study process begins and a series of alternatives to solving the problem are developed and evaluated. Evaluation considers economic, technical, timing, regulatory, and permitting requirements. From there the EPA selects a response action for implementation to remediate the site.

At the time of this report, the NTS has not been listed on the NPL. However, activities are being conducted in compliance with CERCLA requirements as required by DOE Order 5400.4 (U.S. DOE, 1993b). These activities are described in the DOE Order Requirements section below.

\section{Resource Conservation and Recovery Act}

RCRA requires hazardous waste treatment, storage, and disposal (TSD) facilities to obtain federal permission to operate. Interim TSD status is required under 40 CFR 265. Facilities may operate and accept waste under interim status until a 40 CFR 264 Part B permit, to operate a hazardous waste TSD facility and accept waste, is approved (Executive Enterprises, Inc., 1991). To obtain a Part B permit, TSD facilities must conduct site characterization activities to understand the local hydrologic system and to evaluate the potential for the release and migration of waste from the TSD facility. These site characterization activities generally include drilling and sampling of monitoring wells. Approved RCRA Part B permits usually require land disposal facilities to have groundwater monitoring wells and a groundwater monitoring program. RCRA requirements are administered by the Division of Environmental Protection of Nevada's Department of Conservation and Natural Resources.

The Area 5 RWMS is presently operating under RCRA interim status. Three groundwater characterization wells have been drilled in Area 5 to supply information for the RCRA Part B permit (U.S. DOE, 1993a). Initial groundwater samples have been collected for groundwater characterization. Presently, no routine groundwater monitoring is conducted at these wells; however, more groundwater monitoring wells and routine groundwater monitoring may be required as part of an approved RCRA Part B permit.

\section{DOE Order Requirements}

DOE Orders pertaining to groundwater monitoring are included in the 5400 series. Brief descriptions of the pertinent portions of the 5400 series are presented below. 
DOE Order 5400.1. General Environmental Protection Program.

This Order establishes environmental protection program requirements to ensure that DOE operations are in compliance with applicable federal, state, and local environmental protection laws and regulations, executive orders, and DOE internal policies.

DOE Order 5400.1 Chapter III. Environmental Protection Program Plans.

Section 4.a. A Groundwater Management Protection Program for each DOE facility is required. The program should include design and implementation of a groundwater monitoring program to support resource management and comply with applicable environmental laws and regulations; a management program for groundwater protection and remediation including specific SDWA, RCRA, and CERCLA actions; and a remedial action program that is part of the site CERCLA program.

DOE Order 5400.1 Chapter IV. Environmental Monitoring Requirements.

This order contains requirements and guidance for environmental programs concerned with surveillance through measurement, monitoring, and calculation of the effects of operations on the environment and public health.

Section 5.b. Environmental surveillance shall be conducted to monitor the effects of DOE activities on both on-site and off-site environments and their resources. Surveillance shall be designed to verify compliance with applicable environmental laws and regulations, and other environmental commitments; characterize and define trends in physical, chemical and biological condition of environmental media; establish baselines of environmental quality; and identify new or existing environmental quality problems.

Section 9. Groundwater Monitoring Program. Groundwater that is or could be affected by DOE activities shall be monitored to determine and document the effects of operations on groundwater quality and quantity and to demonstrate compliance with DOE requirements and applicable federal, state, and local laws and regulations.

Section 9.a. Groundwater Monitoring Plans. A groundwater monitoring plan shall be developed and shall identify all DOE requirements and regulations applicable to groundwater protection and include monitoring strategy.

Section 9.b. General Requirements.

- Obtain data for the purpose of determining baseline conditions of groundwater quality and quantity.

- Demonstrate compliance with and implementation of all applicable regulations and DOE Orders.

- Provide data to permit the early detection of groundwater pollution or contamination. 
- Provide a reporting mechanism for detected groundwater pollution or contamination.

- Identify existing and potential groundwater contamination sources and to maintain surveillance of these sources.

- Provide data upon which decisions can be made concerning land disposal practices and the management and protection of groundwater resources.

Section 9.c. Site-specific characteristics shall determine monitoring needs. Where appropriate, groundwater monitoring programs shall be designed and implemented in accordance with $40 \mathrm{CFR}$ part 264, sub-part f, or 40 CFR part 265 sub-part f. For multiple groundwater pollutant sources, extensive pollution or unique site problems, programs may require more extensive information. Monitoring for radionuclides shall be in accordance with DOE Orders in the 5400 series dealing with radiation protection of the public and the environment.

DOE Order 5400.4. CERCLA Requirements.

Describes DOE CERCLA policies and procedures. DOE will characterize and remediate contaminated sites to reduce the adverse impacts on public health and the environment regardless of listing on the NPL.

DOE Order 5400.5. Radiation Protection of the Public and the Environment.

DOE will operate its facilities and conduct its activities so that radiation exposures to members of the public are maintained within the limits established, and will protect the environment from radioactive contamination to the extent practical.

DOE Order 5400.5 Chapter II. Requirements for Radiation Protection of the Public and the Environment.

Section 1.d. Public dose limits for drinking-water pathways will be provided at a level of protection for persons consuming water from a public drinking-water supply operated by the DOE that is equivalent to that provided by the public community drinking-water standards of 40 CFR Part 141. Combined ${ }^{226}$ Radium and ${ }^{228}$ Radium shall not exceed $5 \mathrm{pCi} / \mathrm{L}$ and gross alpha activity (including ${ }^{226}$ Radium but excluding radon and uranium) shall not exceed $15 \mathrm{pCi} / \mathrm{L}$. Also, the liquid effluents from DOE activities shall not cause private or public drinking-water systems downstream of the facility discharge to exceed the drinking-water radiological limits in 40 CFR Part 141.

Section 6.a. Compliance with the dose limits listed in this order will be demonstrated by documentation of an appropriate combination of measurements and calculations.

DOE Order 5480.1b. Environment, Safety, and Health Program for Department of Energy Operations.

This program encompasses DOE requirements, activities, and functions that are concerned with controlling air, water, and soil pollution and limiting the risks to the well being of both operating personnel and the general public to acceptably low levels. 


\section{REVIEW OF NTS ANALYTICAL METHODS FOR TRITIUM ACTIVITY}

The presence of measurable tritium in deep groundwater at the NTS is generally considered to be the by-product of nuclear testing. A nuclear detonation produces large amounts of tritium as some water molecules are converted from $\mathrm{H}_{2} \mathrm{O}$ to $\mathrm{HTO}$ by neutron activation. Because tritium is incorporated in the water molecule, tritium will move with groundwater and be unaffected by most processes that normally inhibit the movement of radionuclides in groundwater. Also, the half-life of tritium is sufficiently long so that once tritium is formed, it will be present in measurable concentrations in groundwater for many years. Thus, all groundwater monitoring programs at the NTS analyze samples for the presence of tritium. Since both REECo's and EMSL-LV's groundwater monitoring programs monitor regularly for tritium activity in many of the same wells, a review of their analytical methods for tritium is presented below. A qualitative comparison of REECo's and EMSL-LV's 1992 tritium analyses using the enrichment method is also presented. Copies of REECo's and EMSL-LV's analytical procedures for tritium activity are listed in Appendix C.

\section{Conventional Analytical Method for Tritium Activity}

Both REECo and EMSL-LV conduct the conventional analytical method for tritium activity. The conventional method requires a sample to be distilled to remove dissolved solids and minimize interfering quenching. After distillation, an aliquot is mixed with liquid scintillation solution and counted in a liquid scintillation spectrometer. A background sample and a standard solution of known tritium activity are also counted. The tritium concentration of the sample is calculated by:

$$
\operatorname{Tritium}(p C i / L)=\frac{S-B}{2.22 E V}
$$

where

$\mathrm{S}=$ gross counts per minute of the sample

$B=$ gross counts per minute of the background sample

$\mathrm{E}=$ fractional efficiency determined from a standard solution of known tritium activity

$\mathrm{V}=$ sample size in liters.

REECo reports a maximum detectable concentration (MDC) for the conventional method of approximately $300 \mathrm{pCi} / \mathrm{L}$ (U.S. DOE, 1993a). EMSL-LV reports an MDC ranging from approximately 400 to $700 \mathrm{pCi} / \mathrm{L}$ (U.S. DOE, 1993a). REECo uses distilled water delivered to the NTS from Las Vegas for their background sample. EMSL-LV uses NTS groundwater from Water Well 4 for their background sample. All conventional method results determined by REECo on NTS groundwater samples are reported in DOE/NV's Annual Site Environmental Report (ASER). EMSL-LV reports only conventional method results above the MDC in the ASER.

\section{Enrichment Analytical Method for Tritium Activity}

Both REECo and EMSL-LV conduct the enrichment analytical method for tritium activity. The enrichment method requires a sample to first be distilled and then the distillate's volume decreased by electrolysis to enrich the hydrogen concentration of the sample. After enrichment, the sample is 
vacuum distilled, an aliquot is mixed with liquid scintillation solution, and then counted in a liquid scintillation spectrometer. The tritium concentration of the sample is calculated by:

$$
\operatorname{Tritium}(p C i / L)=\frac{S-B}{2.22 E V D F}
$$

where

$S=$ gross counts per minute of the sample

$\mathrm{B}=$ gross counts per minute of the background sample

$\mathrm{E}=$ fractional efficiency determined from a standard solution of known tritium activity

$\mathrm{V}=$ sample size in liters

$\mathrm{D}=$ dilution factor

$\mathrm{F}=$ enrichment factor.

REECo reports an MDC for the enrichment method of approximately $10 \mathrm{pCi} / \mathrm{L}$ (U.S. DOE, 1993a). EMSL-LV reports an MDC ranging from approximately five to seven $\mathrm{pCi} / \mathrm{L}$ (U.S. DOE, 1993a). REECo enriches each sample to 10 -milliliters volume, uses distilled water delivered to the NTS from Las Vegas for their background sample, and counts each sample for two 100-minute intervals. EMSL-LV enriches each sample to five-milliliters volume, uses NTS groundwater from Water Well 4 for their background sample, and counts each sample for three 100-minute intervals. All enrichment method results determined by REECo and EMSL-LV on NTS groundwater samples are reported in DOE/NV's ASER.

\section{Qualitative Comparison of 1992 Enriched Tritium Results}

Because of the large difference in detection limits between the conventional and enrichment methods, results from the two methods cannot be compared. However, qualitative comparisons can be made between REECo's and EMSL-LV's enriched tritium results. REECo started using the enrichment method in 1991. No results from REECo were submitted for inclusion in the 1991 ASER, so the only data set available for comparison is from 1992. Table 6 lists selected enriched tritium results of groundwater samples collected by REECo and EMSL-LV in 1992 from water-supply wells common to each monitoring program at the NTS. A complete listing of 1992 enriched tritium results from wells common to each program is in Appendix D. When examining the selected 1992 results of the two programs, several observations can be made.

Most of REECo's and EMSL-LV's enriched tritium results are below the MDC for the method and are centered around zero with standard deviations ranging from less than one to about seven pCi/L. Eight REECo results, all from samples collected on October 5, 1992, are substantially below zero $(-17$ to -30$)$. The reasons for these negative results as compared with other results are not explained in the ASER. These results may be caused by in-house analytical errors such as shorter than normal counting times, machine efficiency problems, improper sample enrichment, incomplete distillation after enrichment, bad scintillation solution, background samples with larger than normal tritium content, and/or miscalculations. The nature of such problems should be noted with the reported analytical results. 
Historically, Well $\mathrm{C}$ has exhibited measurable tritium activity with a significant decrease in that activity over time (Russell, 1991; U.S. DOE, 1993a). This is the only well at the NTS that has tritium activity above the enrichment MDC and that is sampled by both REECo's and EMSL-LV's monitoring programs. EMSL-LV's 1992 enriched tritium results for groundwater from Well C for 11 samples range from a maximum of $24 \mathrm{pCi} / \mathrm{L}$ to a minimum of $11 \mathrm{pCi} / \mathrm{L}$ with a mean of $16 \mathrm{pCi} / \mathrm{L}$. REECo's enriched tritium results for groundwater from Well $\mathrm{C}$ for four samples range from a maximum of $23 \mathrm{pCi} / \mathrm{L}$ to a minimum of $-9.1 \mathrm{pCi} / \mathrm{L}$. Although REECo's sample population consists of only four data points, it exhibits a much larger range of values than that of EMSL-LV's sample population. The range is extended at the lower end with two of the results below REECo's MDC. The variability in Well $C$ results reported by REECo and EMSL-LV could occur by variation in several parameters including the activity of the background sample used (B), sample enrichment factor $(F)$, and the machine efficiency $(E)$.

TABLE 6. SELECTED 1992 ENRICHED TRITIUM RESULTS OF GROUNDWATER SAMPLES COLLECTED BY REECo AND EMSL-LV FROM WATER-SUPPLY WELLS COMMON TO EACH MONITORING PROGRAM.

\begin{tabular}{|c|c|c|c|c|c|}
\hline Well & Sample Date & $\begin{array}{l}\text { REECo Result } \\
\quad(\mathrm{pCi} / \mathrm{L})\end{array}$ & $\begin{array}{c}\text { REECo } \\
\text { Standard } \\
\text { Deviation } \\
(\mathrm{pCi} / \mathrm{L})\end{array}$ & $\begin{array}{c}\text { EMSL-LV } \\
\text { Result (pCi/L) }\end{array}$ & $\begin{array}{c}\text { EMSL-LV } \\
\text { Standard } \\
\text { Deviation } \\
(\mathrm{pCi} / \mathrm{L})\end{array}$ \\
\hline Army Well \#1 & $10 / 05 / 92$ & -25 & 6.5 & 3.2 & 1.7 \\
\hline Well 4 & $10 / 05 / 92$ & -23 & 6.6 & 1.6 & 1.6 \\
\hline Well 5C & $10 / 05 / 92$ & -24 & 6.6 & -0.5 & 1.6 \\
\hline Well 8 & $10 / 05 / 92$ & -30 & 6.6 & 1.9 & 1.5 \\
\hline Well C & $\begin{array}{l}01 / 07 / 92 \\
02 / 03 / 92 \\
02 / 24 / 92 \\
04 / 01 / 92 \\
04 / 06 / 92 \\
05 / 12 / 92 \\
06 / 02 / 92 \\
07 / 07 / 92 \\
07 / 13 / 92 \\
08 / 04 / 92 \\
09 / 01 / 92 \\
10 / 05 / 92 \\
11 / 09 / 92 \\
12 / 01 / 92\end{array}$ & $\begin{array}{r}5.3 \\
23\end{array}$ & $\begin{array}{l}4.5 \\
4.5\end{array}$ & $\begin{array}{l}11 \\
24 \\
\\
21 \\
\\
12 \\
19 \\
15 \\
\\
\\
20 \\
12 \\
13 \\
18 \\
17\end{array}$ & $\begin{array}{l}1.8 \\
2.0 \\
\\
2.3 \\
\\
\\
1.7 \\
1.8 \\
1.9 \\
\\
\\
1.8 \\
1.9 \\
1.9 \\
1.7 \\
2.1\end{array}$ \\
\hline Well C-1 & $10 / 05 / 92$ & -17 & 6.7 & 4.7 & 1.6 \\
\hline Well J-12 & $10 / 05 / 92$ & -30 & 6.6 & 0 & 1.4 \\
\hline Well J-13 & $10 / 05 / 92$ & -26 & 6.5 & 3.1 & 1.5 \\
\hline UE-16d & $\begin{array}{l}10 / 05 / 92 \\
11 / 09 / 92\end{array}$ & -26 & 6.5 & 2.3 & 1.4 \\
\hline
\end{tabular}


EMSL-LV uses water from Water Well 4 with a reported tritium activity (enrichment method) of -4.8 to $2.9 \mathrm{pCi} / \mathrm{L}$ which is below their MDC (U.S. DOE, 1993a) for their background sample. REECo uses distilled water delivered to Area 6 from Las Vegas with a reported tritium activity (conventional method) of -300 to $310 \mathrm{pCi} / \mathrm{L}$ (U.S. DOE, 1993a). Concerning REECo's reported results, the 1992 ASER states "commercially available distilled water was used for the background matrix for both the conventional and the enrichment analysis method. Clearly the tritium concentration in the commercial product was frequently higher than in the samples themselves resulting in negative values. This was particularly pronounced in the results obtained from the enrichment method. Thus, except for possible statistical fluctuations, the negative values indicate that the water from the potable supply wells contained less tritium than the commercially available distilled water." Normally, a background sample (also called a laboratory blank) of known very low tritium activity is analyzed periodically (usually at least once daily) to account for normal laboratory bias (for example, systematic errors or background laboratory contamination). As shown in the equation, the activity of the background sample (in counts per minute) is subtracted from the activity of the sample to remove the laboratory bias from the reported value. When using the conventional method with an $\mathrm{MDC}$ of $300 \mathrm{pCi} / \mathrm{L}$, the difference in counts per minutes of Water Well 4 water and the distilled water from Las Vegas does not affect the reported value significantly. However, when using the enrichment method and measuring sample activities close to the MDC, the counts per minute of the background sample will have a significant affect on the reported value (assuming all other variables are held constant).

Surface waters are influenced by atmospheric tritium. Most of Las Vegas' water is supplied from the Colorado River and Lake Mead. Therefore, it is possible that the distilled water delivered to the NTS from Las Vegas and used by REECo for its background samples, has measurable tritium activity because it is produced from surface water. From a hydrologic viewpoint, deep groundwater at the NTS is very old and is not influenced by tritiated atmospheric water. Therefore, no measurable tritium activity should be present in NTS groundwater unless influenced by underground nuclear testing. Also, large quantities of tritium are produced during an underground test, and because tritium can become part of the water molecule, it is an ideal groundwater tracer for monitoring the movement of weapons-related radionuclides. The enrichment method for analyzing tritium activity is an excellent tool for the hydrogeologist to detect small quantities of tritium as it moves with groundwater toward a well. Therefore, for the early detection of radionuclide migration, it is critical that reported tritium activity values from the enrichment method are as accurate as possible. Correcting sample tritium activity by using background samples with measurable tritium resulting in negative or artificially low values will only mask the possible early detection of radionuclide contamination in groundwater.

Reported values can also be influenced by the sample enrichment factor. The enrichment process drives off the lighter $\mathrm{H}_{2} \mathrm{O}$ molecules, reducing the sample volume and concentrating the heavier HTO molecules. As noted above, REECo enriches to a volume of 10 milliliters and EMSL-LV enriches to a volume of five milliliters. These are target reduction volumes and each batch of samples enriched will vary in their final volume. Therefore the sample enrichment factor will vary 
for each laboratory and each batch of samples and thus potentially creating small variations in reported values.

Machine efficiency can also affect reported values. Machine efficiency can vary according to the standards used to calibrate the liquid scintillation spectrometer. Depending on the expected activity of a batch of samples, appropriate standards are selected to calibrate the spectrometer. Different standards will be used when calibrating for high concentration post-shot samples as opposed to standards used to calibrate for drinking-water supply samples. The standards used in conjunction with the samples will vary the machine efficiency and thus create variations in reported values.

On May 13, 1993, a meeting was held at EMSL-LV to address these concerns. Representatives from EMSL-LV, REECo, the Desert Research Institute (DRI), and Lawrence Livermore National Laboratory (LLNL) were present to discuss current laboratory methodology, quality assurance, and quality control. The group recommended the implementation of an interlaboratory comparison study between the attending institutions for their enriched tritium analyses. A copy of this letter with the group's recommendations is in Appendix E. Implementation of this program as recommended by the group would greatly increase the confidence in reported analytical results and would identify problems that might be occurring within individual DOE/NV contractor laboratories.

\section{GROUNDWATER MONITORING NETWORK DESIGN CRITERIA}

Groundwater monitoring network design is defined as the selection of sampling points and sampling frequency to determine physical, chemical, and biological characteristics of groundwater (Loaiciga et al., 1992). In developing a groundwater monitoring network design, consideration should be given to the objectives of the monitoring program; the complex nature of geologic, hydrologic, and source-term factors; the uncertainty of parameters (geologic, hydrologic, and source term) needed in the design process; and the methodology used for network design.

The primary objective of a groundwater monitoring program should be to collect, manage, and analyze geologic, hydrologic, and economic data on groundwater quality and the sources and causes of groundwater contamination. A groundwater monitoring program will also provide other information necessary to enable the federal and state agencies involved to fulfill their statutory responsibilities in regards to protection of groundwater quality, as required by law (Everett, 1984; Todd et al., 1976).

\section{Federal Regulations}

Three major federal laws deal specifically with groundwater contamination related to underground nuclear testing at the NTS: SDWA, RCRA, and CERCLA. Of these, only RCRA has specific groundwater monitoring design requirements. DOE has determined that all expended underground nuclear tests fall under the jurisdiction of CERCLA legislation (Bruce Green, DOE memorandum, June 6, 1987). Although CERCLA does not specify groundwater monitoring design requirements, it is likely that standards and procedures similar to those given in RCRA will be 
applied to CERCLA regulated contamination (Barcelona et al., 1983). DOE Order 5400.1 Chapter IV, Section 9.c also states what groundwater monitoring programs are to be designed and implemented in accordance with RCRA regulations where appropriate.

The basic concept of RCRA groundwater monitoring is to statistically compare wells located hydrologically upgradient and downgradient from a contamination site. Upgradient wells are designed to give an estimate of ambient groundwater quality. Downgradient wells are positioned to determine if contaminant transport is occurring beyond the boundaries of a predetermined Hazardous Waste Management Area (HWMA). An HWMA is defined as an area within a facility's property which encompasses one or more hazardous waste management units or cells. However, if several distinct areas of activity are present which are widely separated within the boundaries of one facility, then separate HWMAs may be established.

By regulation, downgradient wells must be located as close as possible to the edge of hazardous waste management units, and a minimum of one upgradient well must be installed. Generally the spatial placement (both horizontal and vertical) and sampling frequency of downgradient wells are determined by such factors as: likely stratigraphic horizons for contaminant transport, vertical potentiometric gradient, groundwater velocity, dispersion and sorption, and contaminant characteristics. Upgradient monitoring wells must be located in the same hydrostratigraphic section of the aquifer as the downgradient monitoring wells to permit a comparison of groundwater quality. Although only one upgradient well is required by regulation, an adequate number of background monitoring wells must be installed to fully characterize the site, and allow for depth-discrete comparisons of groundwater quality.

\section{Methodology for Groundwater Monitoring Network Design}

The basic purpose of a methodology for monitoring groundwater is to provide a framework for the planning and development of a monitoring program. The following is a outline of a methodology for developing a groundwater monitoring program based on ideas presented by Everett (1984), and include selected concepts from Todd et al. (1976), Loaiciga et al. (1992), Hood et al. (1988), Brown et al. (1989), Luo and Hobbs (1991), and Desmarais (1990). The following steps describe procedures for implementing a groundwater monitoring program. The steps are arranged in chronological order of investigation and implementation.

\section{Define Objectives of the Program}

The objective of a groundwater monitoring program is the primary factor which determines the cost, effort level, and appropriate methodology to be incorporated into a monitoring network (Loaiciga, et al., 1992). The objectives of a monitoring program may include ambient, research monitoring; detection monitoring; and/or compliance monitoring. Detection and compliance monitoring are driven by regulatory considerations, with resultant program objectives defined by applicable state and federal regulations. The main function of detection monitoring is to identify the presence of targeted contaminants at pre-established concentration thresholds as defined by regulators. A typical detection monitoring network would include the placement of upgradient and downgradient monitoring wells in the vicinity of a point or nonpoint pollution source. 
By contrast, a compliance-driven program is generally required by the regulator to monitor the progress and/or success of groundwater remediation activities. In this case, groundwater contamination has already occurred, and the resultant monitoring program is defined by applicable regulations and site-specific factors which evolved out of earlier characterization efforts. While contaminant tracking is the primary function of a compliance program, there is also usually a detection function which is driven by public health considerations.

Generally speaking, most monitoring programs share the broad objectives of collecting, managing, and analyzing groundwater quality, contaminant source, geologic, hydrologic, and economic data. These data are then used by the investigator to address the specific objectives of their monitoring program (e.g., developing remediation strategies; delineating extent of contamination; demonstrating regulatory compliance). These data may also be used by regulators in fulfilling their statutory responsibilities to protect groundwater resources. The data obtained may be used for many purposes including:

- provision of background information and quality,

- detection of quality trends,

- identification and assessment of the sources and causes of contamination,

- planning,

- establishment of water-quality standards and effluent limitations,

- formulation of regulatory control and management actions necessary to protect quality,

- risk assessment

- compliance,

- enforcement, and

- reporting.

An effective monitoring program must recognize the dynamic nature of groundwater systems since both are affected by natural phenomena and man-induced changes. The program must, therefore, be ongoing as the scope and emphasis changes over time, and the objectives must be both flexible and modifiable. The data obtained must continue to be adequate enough to predict quality problems and to formulate plans to prevent contamination.

\section{Identify Source Terms}

The design of a monitoring program requires that the potential sources and causes of groundwater contamination and the methods of waste disposal within an area be identified. The identification of the type of source term such as a point, line, or diffuse source is also important. The potential contaminants for each source must also be identified. 


\section{Identify Receptor Sites}

To evaluate the impact of contamination or potential contamination of groundwater, the usage of the resource becomes a key item. Thus, it is important to define both the quantities of groundwater being extracted and the location of the pumping centers within the monitoring areas. A receptor site can be considered a location where potentially contaminated groundwater becomes available for potential consumption. Receptor site identification also includes determining the type of risk to individual receptors to help define the scope of monitoring which will be required.

\section{Define Hydrogeology}

To understand where and how groundwater occurs and moves within a monitoring area, the hydrogeologic framework must be understood. This information will aid in the design of an effective and efficient groundwater quality monitoring system. Specific information needed for groundwater monitoring programs include:

- aquifer locations, depths, and areal extent,

- transmissivities, storage coefficients, permeabilities, and porosities of aquifers,

- maps of groundwater levels,

- areas and magnitudes of natural groundwater recharge,

- areas and magnitudes of natural groundwater discharge, and

- directions and velocities of groundwater flows.

This information serves as tools for monitoring. All hydrogeologic data are incomplete in a relative sense, what is important is an overall picture of the hydrogeologic setting in the monitoring area. With time and increasing amounts of groundwater data, knowledge of the hydrogeologic setting improves.

\section{Define Existing Groundwater Quality}

Defining existing groundwater quality is extremely important for two reasons: determination of natural (background) water quality as a reference for future sample analysis, and development and confirmation of conceptual groundwater flow models. Water-quality data must be utilized in conjunction with the inventory of source terms and hydrogeologic data to identify the areal extent, direction, and rate of movement of contaminants. Initially, significant portions of a monitoring area may entirely lack groundwater-quality data. However, existing water-quality data, along with hydrogeologic and source-term data, may suggest locations for future sampling and monitoring efforts.

\section{Evaluate Distribution/Attenuation of Contamination}

Percolating water passes vertically through the vadose zone to the water table. In some semiarid or arid climates, contaminants may be retained above the water table, for practical 
purposes, almost permanently. Percolating waters may become perched above layers of low permeability resulting in lateral movement for substantial distances above the water table. Factors controlling the attenuation of contaminants include dilution, filtration, sorption, chemical precipitation, and radioactive decay. Man-made influences on contaminant distribution must also be considered, such as "short-circuiting" of groundwater flow from poorly constructed wells and well pumping. Information on the mobility and attenuation of contaminants is extremely important in considering the possible extent of contaminant distribution from source-term areas.

\section{Prioritize Source Terms}

Initial prioritization of source terms is generally not possible because of incomplete data and knowledge regarding the fate and transport of contaminants in site-specific situations. However, groundwater monitoring programs should be dynamic, and with time, should allow the accurate prioritization of source terms as more information is gained. Of the possible uses of groundwater, usage as potable water supplies is the most important. Therefore, sources that pose a health threat to potable water supplies should have priority over non-health-related uses.

\section{Evaluate Existing Monitoring Programs}

Every effort should be made to incorporate past and ongoing monitoring efforts into a new monitoring program. Information sharing agreements with other characterization and monitoring programs are essential if a monitoring program is to be both comprehensive and cost effective. Data from past and ongoing investigations should be compiled and examined in an effort to minimize the number of sampling sites required. The results of this process will be a priority listing of areas having monitoring deficiencies.

\section{Select and Implement Monitoring Program}

The eight steps as outlined above should result in a good appreciation of the source-term areas with the highest priority and in the identification of data and information deficiencies. Based on this information, with consideration given to budgetary constraints, it is possible to initiate a new monitoring program. The new monitoring program will most likely require the addition of new sampling locations and possibly the deletion of redundant or unneeded sampling locations. In addition to groundwater quality samples, determination of hydrogeologic parameters such as hydraulic gradients (horizontal and vertical), aquifer transmissivity, storage coefficient, and aquifer geometry will be required to begin characterization of the monitoring area.

\section{Review and Interpret Monitoring Results}

Following implementation of a monitoring program, a key function is to collect and review all current monitoring data. New data should be analyzed and compared with existing data to define water-quality trends, refine groundwater flow models, assess the quality of the monitoring program, and define monitoring deficiencies.

Effective data analysis requires that relevant information be available in a concise, comprehensive, timely, economical, and reliable manner. Information contained in a groundwater 
database management system should include, sample location descriptions, quality control/quality assurance criteria, geologic information, hydrologic information, results of measurements, information qualification data to determine "goodness" of data, and temporal or time-series information for detection of trends.

\section{Review and Revise Monitoring Program Based on Monitoring Results}

As new data are collected and analyzed, the quality of the monitoring program can be assessed and monitoring deficiencies defined. To eliminate monitoring and/or characterization information deficiencies, new sampling locations may be added to the monitoring network. Two methods exist for determining the placement of the sampling locations: hydrogeological, and statistical.

The hydrogeological approach is the most commonly used method and is based on qualitative and quantitative hydrogeologic information. The number and location of sampling sites are strictly determined by the hydrogeologic conditions. The hydrogeologic approach generally provides the fundamental data and rationale needed to initiate any groundwater monitoring network.

Once a sufficient amount of hydrogeologic data has been acquired, the statistical approach can be employed to determine areas of monitoring and informational deficiencies, and to approximate hydrogeologic conditions. The hydrogeological approach seeks to define hydrogeological parameters which are extremely complicated and, in general, defy exact description. The statistical approach, most commonly employing geostatistics, utilizes the concept of spatially distributed random variables to: calculate the most accurate predictions (according to well-defined criteria) based on measurements and other relevant information, quantify the accuracy of these predictions, and develop hydrogeologic models which are statistically consistent with available information.

\section{Summary of Methodology for Groundwater Monitoring Network Design}

Successful groundwater monitoring network design must be based on well-defined monitoring objectives. These objectives are generally influenced by federal and state regulations. Source terms and receptor sites must be identified, at least on a regional scale. The hydrogeologic setting in the monitoring area must also be understood, at least on a regional scale. Existing groundwater quality data should be evaluated to determine the natural (background) water quality as a reference for future sample analysis, and to aid in the development and confirmation of conceptual groundwater flow models. The distribution and attenuation of contamination from source terms should be investigated and source terms prioritized to the extent possible with available data. Past and ongoing monitoring efforts should be evaluated, and a new monitoring program implemented based on available information. Following implementation of the monitoring program, data should be collected and reviewed periodically. Existing and new data should be entered into a comprehensive, easily accessible data management system to facilitate data analysis. As new data are acquired, the network design should be revised and updated in response to changes in information needs and the gathered data. It is important to remember that monitoring network design is an iterative process, whereby the monitoring program is reviewed and updated, and conceptual models of groundwater flow and contaminate transport evolve, as data become available. 


\section{Specific Nevada Test Site Design Considerations}

\section{Define Objectives}

Routine groundwater monitoring is conducted at the NTS by REECo's Environmental Monitoring Program and EPA's EMSL-LV's LTHMP. REECo's groundwater monitoring program objectives are as stated in Section 9.b of DOE Order 5400.1 (Ferate, 1993):

- Obtain data for the purpose of determining baseline conditions of groundwater quality and quantity.

- Demonstrate compliance with and implementation of all applicable regulations and DOE Orders.

- Provide data to permit the early detection of groundwater pollution or contamination.

- Provide a reporting mechanism for detected groundwater pollution or contamination.

- Identify existing and potential groundwater contamination sources and to maintain surveillance of these sources.

- Provide data upon which decisions can be made concerning land disposal practices and the management and protection of groundwater resources.

As specified in various LTHMP publications (i.e., R.E. Miller to M.W. Carter, 3 February 1972; U.S. EPA, 1988) the objectives of the LTHMP are:

- Assure public safety,

- Document compliance with standards and regulations,

- Detect migration of radioactivity, and

- Disseminate information.

Under the monitoring program criteria outlined by Logaiciga, et al. (1992), both of the above programs would contain elements of detection and compliance monitoring. The objectives listed above are appropriate objectives for an NTS groundwater monitoring program and would be fulfilled utilizing the methodology presented in this report. As stated previously, the primary objective of a groundwater monitoring program is to collect, manage, and analyze groundwater data and to facilitate compliance with environmental regulations. The REECo and LTHMP objectives are encompassed in this broad objective.

\section{Identify Source Terms}

Identification of source terms for groundwater at the NTS, in a regional sense, is relatively straightforward. LLNL, Los Alamos National Laboratory (LANL), and DOE/NV have extensive records for nuclear testing events conducted at the NTS. These records include the depth of 
emplacement and cavity diameter, and in many cases, extensive pre-test and post-test geologic and hydrologic investigations. Additionally, investigations have been conducted by LLNL, LANL, DRI, and the USGS in the mechanisms of radionuclide transport and attenuation near test cavities. However, on a local level, the mechanics controlling the contamination of groundwater from underground nuclear testing is still poorly understood.

\section{Identify Receptor Sites}

Receptor sites related to underground tests at the NTS can be divided into two categories. The first category includes wells used for potable and non-potable water supply at the NTS. The second category includes the wells and springs located in discharge areas west and south of the NTS as described for the three hydrologic subbasins. Both categories should be considered in the design of a groundwater monitoring network. However, as noted by Daniels et al., (1993), evaluating the risk at individual receptor sites, especially those outside NTS boundaries, is a difficult task. A paucity of appropriate source term data, coupled with inadequate local-scale hydrogeologic information, make risk-based analysis a speculative endeavor at the NTS. Thus, incorporating this important consideration into monitoring programs may be a slow, incremental process as our understanding of site-specific risk improves.

\section{Define Hydrogeology}

As discussed at the beginning of this report, the hydrogeological framework of the NTS is fairly well understood in a regional sense. However, much more information is needed to begin characterization of groundwater flow at the NTS on a local scale. Information is needed to delineate aquifer locations, depths, transmissivities, and areal extents. Distribution of composite hydraulic gradients have been examined on the regional scale, however, the distribution of local hydraulic gradients, both horizontal and vertical, is poorly understood. This information is essential in the design of an effective and efficient groundwater monitoring system.

Groundwater flow to receptor sites west and south of the NTS occurs through valley-fill, volcanic, and carbonate aquifers. Although generally understood on a regional scale, this flow system is extremely complex and poorly understood on the local scale. Groundwater movement within the system consists of combined intergranular, fracture, and possibly cavernous modes of fluid flow. Local cross-aquifer flow caused by structural, depositional, and erosional juxtaposition of aquifers may produce localized deviations in groundwater flow. The structure of the underlying lower clastic aquitard probably produces localized compartmentalization of groundwater flow. Additionally, lateral and vertical gradients, with the potential to greatly influence local groundwater flow, are poorly understood. A great deal of hydrogeologic information is needed to characterize and design a monitoring program for these southern receptor sites.

\section{Define Existing Groundwater Quality}

NTS groundwater quality is discussed in the Hydrogeology of the NTS section of this report. Inorganic water-quality constituents have been used to classify NTS groundwater into three broad geochemical categories or facies. These water-quality data have been used to develop regional scale 
models of groundwater movement at the NTS. However, more work needs to be done to address the conceptual models of local groundwater flow for each source term. Radionuclide occurrence in groundwater has not been thoroughly investigated at the NTS. Radionuclide analyses of groundwater are listed annually in the ASER.

\section{Evaluate Distribution/Attenuation of Contamination}

As discussed earlier in the Identification and Tracking of Radioactive Constituents section of this report, long half-life radionuclides associated with underground nuclear testing are the principal source of groundwater contamination of interest at the NTS. Very limited knowledge on radionuclide distribution and attenuation in groundwater is available, however, radionuclides have been found in groundwater at the NTS as described in Thompson (1991), Russell (1991), and Lyles (1990). The attenuation of radionuclides in groundwater at the NTS is not well understood, but limited research suggests that several processes are important as described earlier. For more detailed discussion of these processes, consult Borg et al. (1976).

\section{Prioritize Source Terms}

Source terms related to underground nuclear testing at the NTS are extremely variable in terms of concentration and volume of contaminants, proximity to receptor sites, and hydrogeologic setting. Present groundwater monitoring programs only address source terms generally, that is, the principal source terms are from underground nuclear testing in Pahute Mesa, Rainier Mesa, and Yucca Flat. Present monitoring programs are only concerned with monitoring receptor sites that may be affected by underground testing, those receptor sites are NTS water-supply wells and any radionuclides that may be leaving the boundaries of the NTS. A risk-based screening analysis of NTS groundwater radionuclide contamination assumed that potential groundwater contamination would first leave Area 20 in the northwestern corner of the NTS. Oasis Valley (19 km southwest of Area 20) was selected as the closet accessible offsite environment (Daniels et al., 1993).

\section{Evaluation of Existing Groundwater Monitoring Programs at NTS}

REECo's and EMSL-LV's groundwater monitoring programs at the NTS are conducted on a routine basis and have been the main focus of this report. Wells utilized by REECo and EMSL-LV for groundwater monitoring at the NTS consist almost exclusively of wells drilled for either water supply or geologic and hydrologic exploration related to nuclear testing. For this reason, the majority of wells currently sampled are located within testing areas of the NTS and do not meet the RCRA definition of either upgradient or downgradient monitoring wells. However, REECo's and EMSL-LV's monitoring of potable and non-potable water-supply wells at the NTS does qualify as monitoring for contamination at NTS receptor sites and as monitoring required by state and federal SDWA.

REECo samples a total of 13 water-supply wells at the NTS, of these wells, three produce water from the valley-fill (alluvium) aquifer, six produce water from various Tertiary volcanic aquifers, and four produce water from carbonate aquifers (one from the upper carbonate aquifer and three from the lower carbonate aquifer). Ten of the wells sampled by REECo are located within or between 
testing areas. Of the remaining three wells, Water Well Army \#1 (lower carbonate aquifer) is located at the extreme southern end of the NTS, in the Ash Meadows subbasin. The other two wells, Water Well J-13 and Water Well J-12 (Tertiary volcanic aquifers), are located in the southwestern corner of the NTS, within the Alkali Flats-Furnace Creek subbasin. These three wells are too distant from underground testing to meet RCRA downgradient water-quality monitoring location criteria.

Of the 10 wells sampled by REECo that are located between testing areas, four could possibly be considered downgradient wells for individual testing areas. Water Well 8, located southwest of Rainier Mesa, is completed in Tertiary volcanic rocks within the Alkali Flats-Furnace Creek subbasin and could be considered a potential downgradient monitoring well for source term areas within Rainier Mesa. USGS Water Well C and Water Well C-1, located at the southern edge of Yucca Flat, are completed in the lower carbonate aquifer. However, the degree of connectivity between these carbonate rocks and those underlying the rest of Yucca Flat is uncertain. These wells may be appropriate downgradient monitoring locations for source-term areas within Yucca Flat provided a large degree of connectivity can be proven. Water Well $5 \mathrm{c}$ is located downgradient from testing in Frenchman Flat and is completed in alluvium. Groundwater is though to exit Frenchman Flat (Ash Meadows subbasin) through the lower carbonate aquifer. This well could be considered a satisfactory downgradient monitoring well for the alluvial aquifer but not for the carbonate aquifers. None of the wells sampled by REECo at the NTS could be considered satisfactory upgradient water quality monitoring wells.

In addition to the 13 water-supply wells sampled by REECo, EMSL-LV samples 16 other wells at the NTS. None of these 16 wells produce water from the valley-fill (alluvium) aquifer. Nine wells produce water from Tertiary volcanic aquifers. Three wells are completed entirely within Paleozoic rocks; two within the lower carbonate aquifer and one within the lower clastic aquitard. Three wells are completed within both Tertiary volcanic and Paleozoic rocks; two wells penetrate lower carbonate rocks and volcanic rocks, and one well encounters volcanic rocks and lower clastic rocks. The lithology of the water producing interval for one well, UE-6d, is uncertain, but is most likely Tertiary volcanic rocks.

All but one of the 16 non-water-supply wells sampled by EMSL-LV are located within or between testing areas on the NTS. Army $6 \mathrm{~A}$ is completed within the lower carbonate aquifer and is located immediately south of the NTS within the Ash Meadows subbasin. Army 6A is too distant from underground testing to be an appropriate downgradient monitoring location. Of the wells located between testing areas, one could be considered a downgradient monitoring well. Well USGS HTH-1 is located south of Rainier Mesa near the divide between the Ash Meadows and Alkali Flat-Furnace Creek subbasins. Because of the uncertainty of the location of this divide, USGS HTH-1 could serve as a downgradient monitoring location pending future study and a better definition of localized groundwater flow patterns south of Rainier Mesa. Wells UE-18r and UE-18t, located south of testing areas in the northern portion of Pahute Mesa, are completed in Tertiary volcanic rocks. These wells are too distant from underground testing to be appropriate downgradient monitoring locations for source-term areas in northern Pahute Mesa. None of the wells sampled by EMSL-LV could be considered satisfactory upgradient water-quality monitoring wells. 
The majority of wells sampled by the groundwater monitoring programs lie within underground test areas. Although unsuitable for use as either upgradient or downgradient water quality monitoring locations, these wells and the data obtained from them are extremely valuable. Water-level measurement, sampling, and special investigation efforts by LLNL, LANL, USGS, and $\mathrm{DRI}$ are essential in producing and refining groundwater flow and contaminate transport models for the NTS, which are required for proper groundwater monitoring network design. Other existing NTS wells should be evaluated for their potential inclusion in the groundwater monitoring network to try to satisfy the RCRA upgradient and downgradient criteria.

\section{Select and Implement Monitoring Program}

Since groundwater monitoring programs already exist, this step is unnecessary.

\section{Review and Interpret Monitoring. Results}

New monitoring data are reported and preliminary data analyses are described in the ASER.

\section{Review and Revise Monitoring Program}

The main emphasis of this report is to review REECo's and EMSL-LV's groundwater monitoring programs in an effort to eliminate redundancy. An effort was also made to examine groundwater monitoring literature to develop a sound groundwater monitoring network program design. As described above, monitoring network design requires detailed evaluations of many different problems. Because of the limited scope of this report and because of the wide range of topics that need to be reviewed in the design criteria listed above, this subsection emphasizes identifying other potential groundwater monitoring locations at the NTS that may help achieve the groundwater monitoring objectives and design requirements.

Potential Groundwater Monitoring Locations. Appendix F contains a listing of wells located at the NTS that was compiled utilizing data from Raytheon Services of Nevada's (RSN) Red Book; RSN hole histories; and USGS, LLNL, LANL, and DRI special investigation reports. The listing contains information on well name, location, ground-surface elevation, total depth, year completed, casing and hole size and depth, completion type and depth, static water level, lithology and sampling status. The wells in the listing are organized by NTS operational area. The wells included in Appendix F consist of wells currently sampled by REECo's Environmental Monitoring Program, EMSL-LV's LTHMP, and those wells which could possibly be available for sampling, that is, those wells which could not be shown to be plugged or otherwise inaccessible in the information sources indicated above.

From the list in Appendix F, approximately 30 wells were selected based on how recently water levels or samples had been obtained, and were then examined for inclusion in the groundwater monitoring network (Table 7). As with the wells sampled currently, most wells were drilled in support of the nuclear testing program and are located in or between underground testing sites. Of the 30 wells examined, six are recommended for immediate inclusion in the groundwater monitoring network based on their locations relative to testing sites, lithology encountered, and regional 
groundwater flow patterns. Five of these six wells are recently completed UGTA/RIFS wells. These are the first wells drilled at the NTS for the sole purpose of groundwater characterization and water-quality monitoring. The other recommended well is a NTS water-supply well with an inoperable pump that needs replacement or repair.

At the outset, it should be strongly emphasized that the designation of these wells as either downgradient or upgradient (see Network Criteria, Table 7) is highly qualitative, and is not intended to adhere to the criteria for upgradient/downgradient monitoring wells as defined in RCRA legislation. Rather, these wells have been determined to be either downgradient or upgradient based on their locations in the framework of regional-scale flow and/or water table maps. Thus, the local-scale hydrogeologic information one would require in siting monitoring wells under RCRA guidelines was not available for this analysis and suggested network design.

TABLE 7. LIST OF POTENTIAL SAMPLING LOCATIONS THAT COULD BE ADDED TO EXISTING GROUNDWATER SAMPLING NETWORK AT THE NEVADA TEST SITE.

\begin{tabular}{|c|c|c|c|c|}
\hline Sampling Location & $\begin{array}{c}\text { NTS } \\
\text { Operational Area }\end{array}$ & Testing Area & Network Criteria & Geology \\
\hline Pahute Mesa \#3 string \#1 & offsite & Pahute Mesa & Downgradient & Tr Volcanics \\
\hline Pahute Mesa \#3 string \#2 & offsite & Pahute Mesa & Downgradient & $\operatorname{Tr}$ Volcanics \\
\hline UE-1q & 1 & Yucca Flat & Downgradient & \\
\hline UE-1a & 1 & Yucca Flat & Downgradient & $\begin{array}{l}\text { Tr Volcanics } \\
\text { and Eleana }\end{array}$ \\
\hline UE-1b & 1 & Yucca Flat & Downgradient & Eleana \\
\hline UE-1 & 1 & Yucca Flat & Downgradient & \\
\hline UE-2ce Water Well & 2 & $\begin{array}{l}\text { Yucca Flat and } \\
\text { Rainier Mesa }\end{array}$ & Downgradient & Pz Carbonates \\
\hline UE-3e \#4 string \#1 & 3 & Yucca Flat & Downgradient & \\
\hline UE-3e \#4 string \#2 & 3 & Yucca Flat & Downgradient & \\
\hline UE-3e \#4 string \#3 & 3 & Yucca Flat & Downgradient & \\
\hline UE-4t string \#1 & 4 & Yucca Flat & Downgradient & Tr Volcanics \\
\hline UE-4t string \#2 & 4 & Yucca Flat & Downgradient & Tr Volcanics \\
\hline USGS HTH \#3 & 5 & Frenchman Flat & $\begin{array}{l}\text { Upgradient or } \\
\text { Downgradient }\end{array}$ & $\mathrm{Pz}$ Carbonates \\
\hline UE-5n & 5 & Frenchman Flat & Downgradient & Alluvium \\
\hline Water Well 5A & 5 & Frenchman Flat & Downgradient & Alluvium \\
\hline ER-6-1 & 6 & Yucca Flat & Downgradient & Pz Carbonates \\
\hline ER-6-1 \#1 & 6 & Yucca Flat & Downgradient & $\operatorname{Tr}$ Volcanics \\
\hline ER-6-2 & 6 & Yucca Flat & Downgradient & Pz Carbonates \\
\hline Well 3 & 6 & Yucca Flat & Downgradient & Alluvium \\
\hline
\end{tabular}


TABLE 7. Continued.

\begin{tabular}{|c|c|c|c|c|}
\hline Sampling Location & $\begin{array}{c}\text { NTS } \\
\text { Operational Area }\end{array}$ & Testing Area & Network Criteria & Geology \\
\hline $\mathrm{U}-7 \mathrm{~cd} \# 1$ & 7 & Yucca Flat & Downgradient & Tr Volcanics \\
\hline UE- $10 \mathrm{j}$ & 8 & $\begin{array}{l}\text { Rainier Mesa } \\
\text { Yucca Flat }\end{array}$ & $\begin{array}{l}\text { Downgradient } \\
\text { Upgradient }\end{array}$ & Pz Carbonates \\
\hline ER-12-1 & 12 & $\begin{array}{l}\text { Rainier Mesa } \\
\text { Yucca Flat }\end{array}$ & $\begin{array}{l}\text { Downgradient } \\
\text { Upgradient }\end{array}$ & $\begin{array}{l}\text { Pz Carbonates } \\
\text { and Eleana }\end{array}$ \\
\hline UE-15d Water Well & 15 & Yucca Flat & Upgradient & Tr Volcanics \\
\hline ER-19-1 & 19 & Pahute Mesa & Downgradient & $\begin{array}{l}\text { Tr Volcanics and } \\
\text { Pz Carbonates }\end{array}$ \\
\hline UE-19h & 19 & Pahute Mesa & $\begin{array}{l}\text { Upgradient or } \\
\text { Downgradient }\end{array}$ & Tr Volcanics \\
\hline ER-20-1 & 20 & Pahute Mesa & Downgradient & Tr Volcanics \\
\hline Pahute Mesa Ex. Hole \#2 & 20 & Pahute Mesa & $\begin{array}{l}\text { Upgradient or } \\
\text { Downgradient }\end{array}$ & Tr Volcanics \\
\hline U-20n PS \#1DD-H & 20 & Pahute Mesa & Downgradient & \\
\hline UE-20n \#1 & 20 & Pahute Mesa & Downgradient & Tr Volcanics \\
\hline
\end{tabular}

UGTA/RIFS well ER-12-1 is located southeast of Rainier Mesa (Ash Meadows subbasin) and is completed in the lower carbonate aquifer and lower clastic aquitard. This well would serve as a downgradient well for source terms from Rainier Mesa. UGTA/RIFS well ER-19-1 is located southwest of Rainier Mesa (Alkali Flat-Furnace Creek subbasin) and is currently completed in Tertiary volcanic rocks. This well would serve as a downgradient well for source terms from Rainier Mesa. UGTA/RIFS wells ER-6-1 and ER-6-2 are located at the southeast and southwest portions of Yucca Flat (Ash Meadows subbasin) downgradient from underground testing. Both wells are completed in the Paleozoic lower carbonate aquifer. UE-10j is located in north Yucca Flat (Ash Meadows subbasin), northwest of Yucca Flat testing. This well is completed in the Paleozoic lower carbonate aquifer and would serve as a much needed upgradient water-quality monitoring location. UE-15d, previously part of the groundwater monitoring network, is presently inaccessible for sampling because of the presence of a nonfunctional pump. If this pump could be repaired, replaced, or at least removed to permit sampling by bailer, the well would be useful additions to the groundwater monitoring network. UE-15d, located in northeast Yucca Flat, is completed in Tertiary volcanic and Paleozoic lower clastic rocks, and would serve as another upgradient monitoring location.

Because of the limited number of monitoring locations available at the NTS, it is not recommended that any wells be deleted from the groundwater monitoring network at this time. Currently, any information obtained on the hydrogeology or hydrogeochemistry of the NTS is valuable in determining both regional and local hydrogeologic settings. 


\section{RECOMMENDATIONS}

Listed below are recommended changes to the NTS groundwater monitoring programs to eliminate redundant and unnecessary sampling and analysis of groundwater, improve the comparability of enriched tritium data from different $\mathrm{DOE} / \mathrm{NV}$ contractor laboratories, and improve the overall groundwater monitoring network.

\section{Sampling Frequency and Constituents to be Analyzed}

\section{Safe Drinking Water Act Requirements}

Under the present groundwater monitoring programs, a large number of samples are collected and analyzed that are not required by the SDWA. Based on the above referenced state and federal SDWA regulations, the following sampling frequency and specific constituent analyses are recommended:

\section{Potable Water-Supply Wells}

- Coliform bacteria- continue present sampling and analysis at consumption points.

- Turbidity - not required.

- Inorganics - continue present sampling and analysis.

- Organics - continue present sampling and analysis.

- Naturally occurring radioactivity - quarterly sampling and analysis for gross alpha activity, ${ }^{226}$ Radium, and ${ }^{228}$ Radium.

- Man-made radioactivity - sample monthly and analyze for gross beta activity, sample quarterly and analyze for tritium (enrichment method) and ${ }^{90}$ Strontium, and a composite of five consecutive days each quarter for ${ }^{131}$ Iodine.

- Total Trihalomethanes - not required.

- Secondary standards - continue present sampling and analysis.

\section{Non-Potable Water-Supply Wells}

- State of Nevada does not require monitoring, see recommendations under DOE Orders.

\section{Drinking-Water Consumption Points}

- Continue present sampling and analysis for coliform bacteria, $\mathrm{pH}$, residual chlorine, and inorganic constituents.

- State of Nevada does not require radioactivity monitoring at consumption points, see recommendations under DOE Orders.

- No sampling required, see recommendations under DOE Orders. 


\section{Non-Water Supply Wells}

- No sampling required, see recommendations under DOE Orders.

\section{DOE Order Requirements}

DOE Orders in the 5400 series do not list specific groundwater monitoring sampling frequency or constituent analysis requirements. DOE Order 5400.5, Radiation Protection of the Public and the Environment, lists radiation protection dose limits, but does not recommend specific groundwater sampling frequency or constituent analysis requirements. DOE Order 5400.1 lists general environmental protection and groundwater monitoring program requirements, but does not make specific monitoring recommendations. Therefore, because DOE Orders are not specific, the following recommendations are subjective:

\section{Potable Water-Supply Wells}

- Tritium - sample quarterly, analyze with enrichment method for early detection of movement of radionuclide contaminated groundwater.

- Gamma activity - sample annually until enriched tritium activity above the MDC is observed.

- ${ }^{238}$ Plutonium and ${ }^{239+240}$ Plutonium - sample annually until enriched tritium activity above the MDC is observed.

- Other radionuclide analysis covered under SDWA requirements.

\section{Non-Potable Water-Supply Wells}

- Tritium - sample quarterly, analyze with enrichment method for early detection of movement of radionuclide contaminated groundwater.

- Gamma activity - sample annually until enriched tritium activity above the MDC is observed.

- ${ }^{238}$ Plutonium and ${ }^{239+240}$ Plutonium - sample annually until enriched tritium activity above the MDC is observed.

- Other radionuclide analysis not recommended until enriched tritium activity is consistently above the MDC.

\section{Drinking-Water Consumption Points}

- Tritium - sample weekly, analyze with conventional method only. Reduce conventional analysis of distilled water from Las Vegas to monthly.

- Other radionuclides - continue present sampling and analysis.

- Tritium - sample quarterly, analyze with enrichment method for early detection of movement of radionuclide contaminated groundwater. 
- Gamma activity - sample annually until enriched tritium activity above the MDC is observed.

- 238Plutonium and 239+240Plutonium - sample annually until enriched tritium activity above the MDC is observed.

- Other radionuclide analysis not recommended unless enriched tritium activity is consistently above the MDC.

\section{Non-Water Supply Wells}

- Continue LTHMP frequency and constituent analysis except for water-supply wells. Monitor water-supply wells for constituents and on frequency described above.

\section{Analytical Methods for Tritium Analysis}

Based on the review of analytical methodology for tritium analysis used by REECo and EMSL-LV, the following recommendations are:

- Note with published results analytical problems resulting in very negative values.

- Use water with very low tritium activity for REECo's background sample in their enrichment method for analysis of tritium activity. Recommend using water from Water Well 4, same as EMSL-LV.

- Institute interlaboratory comparison program for enriched tritium analysis as recommended by tritium subcommittee letter (Appendix E). Quarterly analysis of tritium activity in water-supply wells by both REECo and EMSL-LV using the enrichment method should continue in FY94 until results from interlaboratory comparison program can be reviewed. FY94 quarterly water-supply well samples should be collected by one contractor and splits supplied to both REECo's and EMSL-LV's laboratory.

\section{Groundwater Monitoring Network Design}

The inclusion of other wells, presently not sampled, in the existing groundwater monitoring programs is recommended to improve the overall monitoring network. As discussed above, more upgradient and downgradient sampling locations are needed to achieve groundwater monitoring network objectives. The following steps are recommended:

- Begin negotiations with DOE/NV's Environmental Restoration Division to gain access to UGTA/RIFS wells for inclusion in the groundwater monitoring network.

- Add wells ER-6-1, ER-6-2, ER-12-1, ER-19-1, and UE-10j to the network and sample at non-water-supply well frequency.

- Repair or remove pump at well UE-15d and sample at non-water-supply well frequency.

- Begin the evaluation of 30 other selected wells to determine their potential for inclusion in the network. 
- Give consideration to the establishment of a comprehensive and easily accessible data base for past and current data as discussed in the groundwater monitoring program network design methodology section.

- Utilize trained hydrogeologists familiar with the hydrogeology of the NTS and the objective's of the monitoring programs to annually evaluate the groundwater monitoring program.

- Continue to fund local and regional groundwater studies, and source-term evaluations, to refine conceptual models of NTS radionuclide transport to facilitate refinement of monitoring network. 


\section{REFERENCES}

Barcelona, M.J., J.P. Gibb and R.A. Miller, 1983. A Guide to the Selection of Materials for Monitoring Well Construction and Groundwater Sampling. Ilinois State Water Survey, ISWS Contract Report 327, Urbana, Il., 78 p.

Blankennagel, R.K. and J.E. Weir, Jr., 1973. Geohydrology of the Eastern Part of Pahute Mesa, Nevada Test Site, Nye County, Nevada. U.S. Geological Survey Professional Paper 712-B, 35 p.

Borg, I.Y., R. Stone, B. Levy and L.D. Ramspott, 1976. Information Pertinent to the Migration of Radionuclides in Ground Water at the Nevada Test Site, Part 1: Review and Analysis of Existing Information. Lawrence Livermore National Laboratory Report UCRL-52078 Pt. 1, 216 p.

Brown, S., D.R. Lincoln and W.A. Wallace, 1989. Application of the Observational Method to Remediation of Hazardous Waste Sites. CH2M HILL Publication, Bellevue, Wa., 16 p.

Bryant, E.A. and J. Fabryka-Martin, 1991. Survey of Hazardous Materials Used in Nuclear Testing. Los Alamos National Laboratory Report LA-12014-MS, 12 p.

Chapman, J.B. and B.F. Lyles, 1993. Groundwater Chemistry at the Nevada Test Site: Data and Preliminary Interpretations. Desert Research Institute, Water Resources Center Publication \#45100, Draft, 41 p.

Daniels, J.I., R. Andricevic, L.R. Anspaugh and R.L. Jacobson, 1993. Risk-Based Screening Analysis of Groundwater Contaminated by Radionuclides Introduced at the Nevada Test Site (NTS). Lawrence Livermore National Laboratory Report UCRL-ID-112789, 29 p.

Desmarais, R., 1990. Principles of groundwater Quality Monitoring. Encyclopedia of Fluid Mechanics, Vol. 10 p. 611-622.

Everett, L.G., 1984. Groundwater Monitoring. Genium Publishing Corp., Schenectady, NY, 440p.

Executive Enterprises, Inc., 1991. Environmental Regulation Course, A Basic Comprehensive Course On Environmental Regulation. Executive Enterprises, Inc., August 6-8, 1991, Las Vegas, Nevada, Course Manual, Section 10-11.

Hood, W.K., A.A. Myers and D.L. Totman, 1988. In: Proceedings of the FOCUS Conference on Southwestern Groundwater Issues.

Loaiciga, H.A., R.J. Charbeneau, L.G. Everett, G.E. Fogg, B.F. Hobbs and S. Rouhani, 1992. Review of Ground-Water Quality Monitoring Network Design. Journal of Hydraulic Engineering, Vol. 118, No. 1, p. 11-37.

Lou Y. and B.F. Hobbs, 1991. A general Framework for Monitoring and Control of Groundwater Contamination. In: Surface and Ground Water Quality--Pollution Prevention, Remediation, and the Great Lakes Conference, American Water Resources Association, p. 183-198. 
Lyles, B.F., 1990. Tritium Variations in Groundwater on the Nevada Test Site. Desert Research Institute, Water Resources Center Publication No. 45086, 85 p.

Marsh K.V., 1992. Hydrology and Radionuclide Migration Program 1988 Progress Report. Lawrence Livermore National Laboratory, UCRL-53779-88, 19 p. and Appendices.

Russell, C.E., 1991. Assessment of the Nevada Test Site Monitoring Well System. Desert Research Institute, Water Resources Center Publication \#45072 (DOE/NV/10384-31), 87 p.

Schoff, S.L. and J.E. Moore, 1964. Chemistry and Movement of Ground Water, Nevada Test Site. U.S. Geological Survey Trace Elements Investigations Report TEI-838, 75 p.

Thompson, J.L, 1991. Laboratory and Field Studies Related to the Hydrology/Radionuclide Migration Project, October 1, 1989-September 30, 1990. Los Alamos National Laboratory Progress Report LA-12100-PR, Los Alamos, New Mexico, 38 p.

Todd D.K., R.M. Tinlin, K.D. Schmidt and L.G. Everett, 1976. Monitoring Groundwater Quality: Monitoring Methodology. U.S. Environmental Protection Agency, A-600/4-76-026, 154 p.

U.S. Department of Energy, 1993a. U.S. Department of Energy Nevada Field Office Annual Site Environmental Report - 1992. Editors: S.C. Black, A.R. Lathan and Y.E. Townsend, DOE/NV/10630-66 Volumes I and II, Draft, September, 1993.

U.S. Department of Energy, 1993b. Announced United States Nuclear Tests: July 1945 through December 1992. DOE/NV/209 (Rev. 13), May 1993.

U.S. Department of Energy, 1993c. Groundwater Protection Management Program Plan for the DOE Nevada Field Office. U.S. Department of Energy, Nevada Field Office, February 19, 1993.

U.S. Department of Energy, 1988. Environmental Survey Preliminary Report, Nevada Test Site, Mercury, Nevada. U.S. Department of Energy, Office of Environmental Audit, Washington, D.C.

U.S. Environmental Protection Agency, 1988. Offsite Environmental Monitoring Report, Radiation Monitoring Around United States Nuclear Test Areas 1987. Report EPA/600/4-88/021, variable paging.

Waddell, R.K., J.H. Robison and R.K. Blankennagel, 1984. Hydrology of Yucca Mountain and Vicinity, Nevada-California--Investigative Result through Mid-1983: U.S. Geological Survey Water-Resources Investigations Report 84-4267, 35 p.

White, A.F., 1979. Geochemistry of Groundwater Associated with Tuffaceous Rocks, Oasis Valley, Nevada: U.S. Geological Survey Professional Paper 712-E, 25 p.

Winograd, I.J. and W. Thordarson, 1975. Hydrogeologic and Hydrogeochemical Framework, South-Central Great Basin, Nevada-California, with Special Reference to the Nevada Test Site: U.S. Geological Survey Professional Paper 712-C, 119 p. 
Wood, D.B., 1992. Ground-Water Data Collected at the Nevada Test Site and Vicinity, Nye County, Nevada, Water Years 1988-89. U.S. Geological Survey Open-File Report 92-130, 50 p. 
APPENDIX A

ANNOUNCED UNDERGROUND NUCLEAR WEAPONS TESTS AT THE NEVADA TEST SITE CONDUCTED BELOW OR NEAR

THE GROUNDWATER TABLE (FROM MARSH, 1992) 


\begin{tabular}{|c|c|c|c|c|c|c|}
\hline Event name & Hole Name & Sponsor & Date & $\begin{array}{c}\text { Depth of } \\
\text { Burial } \\
\text { (meters) }\end{array}$ & $\begin{array}{c}\text { Water } \\
\text { Level } \\
\text { (meters) }\end{array}$ & $\begin{array}{c}\text { Water } \\
\text { Level } \\
\text { Measurement }\end{array}$ \\
\hline Bilby & $\mathrm{U} 3 \mathrm{CN}$ & LANL & $09 / 13 / 63$ & 714.300 & 503 & est. \\
\hline Wagtail & U3AN & LANL & $03 / 03 / 65$ & 749.600 & 509 & est. \\
\hline Cup & $\mathrm{U} 9 \mathrm{CB}$ & LLNL & $03 / 26 / 65$ & 538.890 & 562 & est. \\
\hline Buteo & $\mathrm{U} 20 \mathrm{~A}$ & LANL & $05 / 12 / 65$ & 695.550 & 658 & meas. \\
\hline Cambric & U5E & LLNL & $05 / 14 / 65$ & 294.740 & 213 & est. \\
\hline Diluted Waters & U5B & LLNL/DoD & $06 / 16 / 65$ & 192.630 & 213 & est. \\
\hline Bronze & U7F & LANL & $07 / 23 / 65$ & 530.810 & 553 & est. \\
\hline Corduroy & U10K & LLNL & $12 / 03 / 65$ & 678.790 & 568 & meas. \\
\hline Buff & U3DH & LANL & $12 / 16 / 65$ & 500.410 & 520 & est. \\
\hline Lampblack & U7I & LANL & $01 / 18 / 66$ & 561.480 & 549 & est. \\
\hline $\operatorname{Rex}$ & $\mathrm{U} 20 \mathrm{HE}$ & LLNL & $02 / 24 / 66$ & 671.170 & 642 & meas. \\
\hline Chartreuse & U19D & LANL & $05 / 06 / 66$ & 666.750 & 662 & meas. \\
\hline Piranha & U7E & LANL & $05 / 13 / 66$ & 548.720 & 533 & est. \\
\hline Dumont & $\mathrm{U} 2 \mathrm{~T}$ & LLNL & $05 / 19 / 66$ & 670.870 & 549 & est. \\
\hline Piledriver & U15A.01 & LANL/DoD & $06 / 02 / 66$ & 462.690 & 457 & est. \\
\hline Tan & U7K & LANL & $06 / 03 / 66$ & 560.680 & 511 & est. \\
\hline Puce & U3BS & LANL & $06 / 10 / 66$ & 485.550 & 504 & est. \\
\hline Halfbeak & U19B & LANL & $06 / 30 / 66$ & 819.300 & 645 & meas. \\
\hline Daiquiri & U7O & LANL & $09 / 23 / 66$ & 561.150 & 561 & est. \\
\hline Greeley & $\mathrm{U} 20 \mathrm{G}$ & LLNL & $12 / 20 / 66$ & 1216.460 & 615 & meas. \\
\hline Agile & $\mathrm{U} 2 \mathrm{~V}$ & LLNL & $02 / 23 / 67$ & 733.350 & 564 & est. \\
\hline Commodore & $\mathrm{U} 2 \mathrm{AM}$ & LLNL & $05 / 20 / 67$ & 745.240 & 567 & est. \\
\hline Scotch & U19AS & LANL & $05 / 23 / 67$ & 977.390 & 672 & meas. \\
\hline Knickerbocker & $\mathrm{U} 20 \mathrm{D}$ & LLNL & $05 / 26 / 67$ & 630.630 & 632 & meas. \\
\hline Zaza & $\mathrm{U} 4 \mathrm{C}$ & LANL & $09 / 27 / 67$ & 667.000 & 535 & est. \\
\hline Lanpher & $\mathrm{U} 2 \mathrm{X}$ & LLNL & $10 / 18 / 67$ & 715.060 & 552 & est. \\
\hline Cobbler & U7U & LANL & $11 / 08 / 67$ & 667.120 & 556 & est. \\
\hline Knox & U2AT & LLNL & $02 / 21 / 68$ & 644.800 & 549 & est. \\
\hline Stinger & U19L & LANL & $03 / 22 / 68$ & 667.760 & 640 & meas. \\
\hline Boxcar & U20I & LLNL & $04 / 26 / 68$ & 1165.860 & 580 & meas. \\
\hline Rickey & $\mathrm{U} 19 \mathrm{C}$ & LANL & $06 / 15 / 68$ & 683.280 & 707 & meas. \\
\hline Chateaugay & $\mathrm{U} 20 \mathrm{~T}$ & LLNL & $06 / 28 / 68$ & 607.230 & 632 & est. \\
\hline Sled & U19I & LANL & $08 / 29 / 68$ & 728.880 & 667 & meas. \\
\hline Noggin & U9BX & LLNL & $09 / 06 / 68$ & 582.170 & 558 & est. \\
\hline Benham & $\mathrm{U} 20 \mathrm{C}$ & LLNL & $12 / 19 / 68$ & 1402.080 & 641 & meas. \\
\hline Blenton & $\mathrm{U} 7 \mathrm{P}$ & LANL & $04 / 30 / 69$ & 557.730 & 553 & est. \\
\hline Thistle & U7T & LANL & $04 / 30 / 69$ & 560.470 & 578 & est. \\
\hline Purse & $\mathrm{U} 20 \mathrm{~V}$ & LLNL & $05 / 07 / 69$ & 598.780 & 601 & meas. \\
\hline Jorum & $\mathrm{U} 20 \mathrm{E}$ & LLNL & $09 / 16 / 69$ & 1160.890 & 556 & meas. \\
\hline Pipkin & $\mathrm{U} 20 \mathrm{~B}$ & LLNL & $10 / 08 / 69$ & 623.620 & 640 & est. \\
\hline Calabash & U2AV & LLNL & $10 / 29 / 69$ & 624.840 & 578 & est. \\
\hline Grape A & U7S & LANL & $12 / 17 / 69$ & 550.670 & 568 & est. \\
\hline
\end{tabular}




\begin{tabular}{|c|c|c|c|c|c|c|}
\hline Event name & Hole Name & Sponsor & Date & $\begin{array}{c}\text { Depth of } \\
\text { Burial } \\
\text { (meters) }\end{array}$ & $\begin{array}{c}\text { Water } \\
\text { Level } \\
\text { (meters) }\end{array}$ & $\begin{array}{c}\text { Water } \\
\text { Level } \\
\text { Measurement }\end{array}$ \\
\hline Grape B & U7V & LANL & $02 / 04 / 70$ & 554.030 & 565 & est. \\
\hline Shaper & U7R & LANL & $03 / 23 / 70$ & 560.440 & 549 & est. \\
\hline Handley & U20M & LLNL & $03 / 26 / 70$ & 1209.000 & 387 & meas. \\
\hline Tijeras & U7Y & LANL & $10 / 14 / 70$ & 560.620 & 543 & meas. \\
\hline Carpetbag . & U2DG & LLNL & $12 / 17 / 70$ & 661.700 & 576 & est. \\
\hline Miniata & U2BU & LLNL & $07 / 08 / 71$ & 528.830 & 491 & meas. \\
\hline Algodones & U3JN & LANL & $08 / 18 / 71$ & 527.610 & 501 & est. \\
\hline Monero & U3JQ & LANL & $05 / 19 / 72$ & 537.350 & 526 & meas. \\
\hline Oscuro & $\mathrm{U} 7 \mathrm{Z}$ & LANL & $09 / 21 / 72$ & 560.220 & 521 & est. \\
\hline Miera & $\mathrm{U} 7 \mathrm{AD}$ & LANL & $03 / 08 / 73$ & 568.760 & 553 & est. \\
\hline Angus & U3JG & LANL & $04 / 25 / 73$ & 452.930 & 472 & meas. \\
\hline Starwort & U2BS & LLNL & $04 / 26 / 73$ & 563.880 & 526 & meas. \\
\hline Almendro & U19V & LANL & $06 / 06 / 73$ & 1063.750 & 686 & meas. \\
\hline Latir & U4D & LANL & $02 / 27 / 74$ & 640.990 & 503 & est. \\
\hline Escabosa & U7AC & LANL & $07 / 10 / 74$ & 639.990 & 545 & est. \\
\hline Portmanteau & $\mathrm{U} 2 \mathrm{AX}$ & LLNL & $08 / 30 / 74$ & 655.290 & 585 & meas. \\
\hline Stanyan & U2AW & LLNL & $09 / 26 / 74$ & 572.990 & 553 & meas. \\
\hline Topgallant & U4E & LANL & $02 / 28 / 75$ & 713.200 & 515 & meas. \\
\hline Cabrillo & $\mathrm{U} 2 \mathrm{DR}$ & LLNL & $03 / 07 / 75$ & 600.500 & 567 & meas. \\
\hline Obar & U7AG & LANL & $04 / 30 / 75$ & 569.000 & 521 & meas. \\
\hline Tybo & $\mathrm{U} 20 \mathrm{Y}$ & LLNL & $05 / 14 / 75$ & 765.000 & 630 & meas. \\
\hline Mizzen & $\mathrm{U7AH}$ & LANL & $06 / 03 / 75$ & 637.000 & 515 & meas. \\
\hline Stilton & $\mathrm{U} 20 \mathrm{P}$ & LLNL/DoD & $06 / 03 / 75$ & 731.500 & 280 & meas. \\
\hline Mast & U19U & LANL & $06 / 19 / 75$ & 911.300 & 666 & meas. \\
\hline Camembert & U19Q & LLNL & $06 / 26 / 75$ & 1310.600 & 668 & meas. \\
\hline Kasseri & $\mathrm{U} 20 \mathrm{Z}$ & LLNL & $10 / 28 / 75$ & 1265.000 & 628 & meas. \\
\hline Inlet & U19F & LANL & $11 / 20 / 75$ & 819.000 & 703 & meas. \\
\hline Chiberta & U2EK & LLNL & $12 / 20 / 75$ & 716.000 & 536 & meas. \\
\hline Muenster & U19E & LLNL & $01 / 03 / 76$ & 1452.400 & 676 & meas. \\
\hline Esrom & U7AK & LLNL & $02 / 04 / 76$ & 655.300 & 523 & meas. \\
\hline Keelson & U7AI & LANL & $02 / 04 / 76$ & 640.000 & 498 & meas. \\
\hline Fontina & U20F & LLNL & $02 / 12 / 76$ & 1219.000 & 595 & meas. \\
\hline Cheshire & $\mathrm{U} 20 \mathrm{~N}$ & LLNL & $02 / 14 / 76$ & 1167.000 & 625 & meas. \\
\hline Estuary & Ü19G & LANL & $03 / 09 / 76$ & 868.100 & 627 & meas. \\
\hline Colby & U20AA & LLNL & $03 / 14 / 76$ & 1273.400 & 571 & meas. \\
\hline Pool & U19P & LANL & $03 / 17 / 76$ & 879.300 & 690 & meas. \\
\hline Strait & U4A & LANL & $03 / 17 / 76$ & 780.300 & 506 & meas. \\
\hline Billet & U7AN & LANL & $07 / 27 / 76$ & 635.500 & 503 & meas. \\
\hline Banon & $\mathrm{U} 2 \mathrm{DZ}$ & AWRE/LLNL & $08 / 26 / 76$ & 536.400 & 548 & meas. \\
\hline Rudder & U7AJS & LANL & $12 / 28 / 76$ & 640.000 & 520 & meas. \\
\hline Marsilly & U2EL & LLNL & $04 / 05 / 77$ & 690.000 & 541 & meas. \\
\hline Bulkhead & U7AM & LANL & $04 / 27 / 77$ & 594.300 & 532 & meas. \\
\hline
\end{tabular}




\begin{tabular}{|c|c|c|c|c|c|c|}
\hline Event name & Hole Name & Sponsor & Date & $\begin{array}{c}\text { Depth of } \\
\text { Burial } \\
\text { (meters) }\end{array}$ & $\begin{array}{c}\text { Water } \\
\text { Level } \\
\text { (meters) }\end{array}$ & $\begin{array}{c}\text { Water } \\
\text { Level } \\
\text { Measurement }\end{array}$ \\
\hline Crewline & U7AP & LANL & $05 / 25 / 77$ & 563.900 & 503 & meas. \\
\hline Strake & U7AE & LANL & $08 / 04 / 77$ & 518.200 & 541 & meas. \\
\hline Scantling & $\mathrm{U} 4 \mathrm{H}$ & LANL & $08 / 19 / 77$ & 701.000 & 511 & meas. \\
\hline Sandreef & U7AQ & LANL & $11 / 09 / 77$ & 701.000 & 503 & meas. \\
\hline Farallones & U2FA & LLNL & $12 / 14 / 77$ & 668.000 & 554 & meas. \\
\hline Reblochon & U2EN & LLNL & $02 / 23 / 78$ & 658.400 & 540 & est. \\
\hline Iceberg & U4G & LANL & $03 / 23 / 78$ & 640.000 & 507 & meas. \\
\hline Transom & $\mathrm{U} 4 \mathrm{~F}$ & LANL & $05 / 10 / 78$ & 640.000 & 507 & meas. \\
\hline Lowball & U7AV & LANL & $07 / 12 / 78$ & 563.900 & 501 & meas. \\
\hline Panir & U19YS & LLNL & $08 / 31 / 78$ & 681.000 & 645 & est. \\
\hline Rummy & U7AU & LANL & $09 / 27 / 78$ & 640.000 & 504 & est. \\
\hline Quargel & $\mathrm{U} 2 \mathrm{FB}$ & AWRE/LLNL & $11 / 18 / 78$ & 542.000 & 539 & meas. \\
\hline Farm & $\mathrm{U} 20 \mathrm{AB}$ & LLNL & $12 / 16 / 78$ & 689.000 & 649 & est. \\
\hline Quinella & U4L & LANL & $02 / 08 / 79$ & 579.100 & 512 & est. \\
\hline Pepato & $\mathrm{U} 20 \mathrm{AD}$ & LLNL & $06 / 11 / 79$ & 681.000 & 579 & meas. \\
\hline Hearts & U4N & LANL & $09 / 06 / 79$ & 640.000 & 507 & meas. \\
\hline Pyramid & U7BE & LANL & $04 / 16 / 80$ & 579.100 & 540 & meas. \\
\hline Colwick & U20AC & LLNL & $04 / 26 / 80$ & 633.000 & 630 & est. \\
\hline Kash & U20AF & LLNL & $06 / 12 / 80$ & 645.000 & 602 & est. \\
\hline Tafi & U20AE & LLNL & $07 / 25 / 80$ & 680.000 & 607 & meas. \\
\hline Baseball & U7BA & LANL & $01 / 15 / 81$ & 563.900 & 512 & meas. \\
\hline Rousanne & U4P & LANL & $11 / 12 / 81$ & 518.200 & 495 & est. \\
\hline Jornada & U4J & LANL & $01 / 28 / 82$ & 640.000 & 507 & est. \\
\hline Molbo & $\mathrm{U} 20 \mathrm{AG}$ & LLNL & $02 / 12 / 82$ & 638.000 & 614 & meas. \\
\hline Bouschet & U3LA & LANL & $05 / 07 / 82$ & 563.900 & 500 & est. \\
\hline Atrisco & U7BP & LANL & $08 / 05 / 82$ & 640.100 & 538 & meas. \\
\hline Borrego & U7BR & LANL & $09 / 29 / 82$ & 563.900 & 501 & meas. \\
\hline Turquoise & U7BU & LANL & $04 / 14 / 83$ & 533.000 & 500 & est. \\
\hline Chancellor & U19AD & LANL & $09 / 01 / 83$ & 625.000 & 647 & meas. \\
\hline Techado & $\mathrm{U} 4 \mathrm{O}$ & LANL & $09 / 22 / 83$ & 533.400 & 500 & est. \\
\hline Tortugas & U3GG & LANL & $03 / 01 / 84$ & 640.100 & 497 & meas. \\
\hline Mundo & U7BO & LANL & $05 / 01 / 84$ & 567.000 & 558 & est. \\
\hline Caprock & $\mathrm{U} 4 \mathrm{Q}$ & LANL & $05 / 31 / 84$ & 600.000 & 500 & est. \\
\hline Kappeli & U20AM & LLNL & $07 / 25 / 84$ & 640.000 & 652 & meas. \\
\hline Breton & U4AR & LLNL & $09 / 13 / 84$ & 483.000 & 505 & est. \\
\hline Hermosa & U7BS & LANL & $04 / 02 / 85$ & 640.100 & 506 & meas. \\
\hline Towanda & U19AB & LANL & $05 / 02 / 85$ & 664.500 & 614 & meas. \\
\hline Salut & U20AK & LLNL & $06 / 12 / 85$ & 608.000 & 622 & meas. \\
\hline Serena & $\mathrm{U} 20 \mathrm{AN}$ & LLNL & $07 / 25 / 85$ & 597.000 & 606 & meas. \\
\hline Kinibito & U3ME & LANL & $12 / 05 / 85$ & 579.100 & 488 & est. \\
\hline Glencoe & U4I & LANL & $03 / 22 / 86$ & 609.600 & 522 & est. \\
\hline Jefferson & U20AI & LLNL & $04 / 22 / 86$ & 609.000 & 625 & meas. \\
\hline
\end{tabular}




\begin{tabular}{|c|c|c|c|c|c|c|}
\hline Event name & Hole Name & Sponsor & Date & $\begin{array}{c}\text { Depth of } \\
\text { Burial } \\
\text { (meters) }\end{array}$ & $\begin{array}{c}\text { Water } \\
\text { Level } \\
\text { (meters) }\end{array}$ & $\begin{array}{c}\text { Water } \\
\text { Level } \\
\text { Measurement }\end{array}$ \\
\hline Darwin & U20AQ & LLNL & $06 / 25 / 86$ & 549.000 & 574 & meas. \\
\hline Cybar & U19AR & LANL & $07 / 17 / 86$ & 627.900 & 645 & meas. \\
\hline Aleman & U3KZ & LANL & $09 / 11 / 86$ & 502.900 & 500 & est. \\
\hline Labquark & U19AN & LLNL & $09 / 30 / 86$ & 616.000 & 641 & meas. \\
\hline Belmont & U20AS & LLNL & $10 / 16 / 86$ & 605.000 & 613 & meas. \\
\hline Gascon & $\mathrm{U} 4 \mathrm{~T}$ & LANL & $11 / 14 / 86$ & 593.140 & 505 & est. \\
\hline Bodie & U20AP & LLNL & $12 / 13 / 86$ & 635.000 & 652 & meas. \\
\hline Hardin & U20AV & LLNL & $04 / 30 / 87$ & 625.000 & 632 & meas. \\
\hline Tahoka & U3MF & LANL & $08 / 13 / 87$ & 640.100 & 493 & est. \\
\hline Borate & U2GE & LLNL & $10 / 23 / 87$ & 542.500 & 567 & meas. \\
\hline Kernville & U20AR & LLNL & $02 / 15 / 88$ & 541.600 & 561 & est. \\
\hline Comstock & U20AY & LLNL & $06 / 02 / 88$ & 620.300 & 626 & meas. \\
\hline Alamo & U19AU & LANL & $07 / 07 / 88$ & 621.800 & 624 & meas. \\
\hline Bullfrog & U4AU & LLNL & $08 / 30 / 88$ & 489.200 & 500 & meas. \\
\hline
\end{tabular}


APPENDIX B

SAFE DRINKING WATER ACT REGULATIONS

B-1 
NEVADA REVISED STATUTES 
of the state and no municipal corporation. county or other political subdivision having jurisdiction over water pollution prevention. abatement and control may permit. under authority of such jurisdiction. the discharge of wastes into the waters of the state which would resuit in the pollution of any of such waters in excess of any water quality standard promulgated by the commis. sion. (1973. p. 1718.)

445.351. Provisions of Title 48 of NRS unaffected.

Nothing in NRS 445.131 to 445.354 . inclusive. shall be construed to amend. modify or supersede the provisions of Title 48 of NRS or any rule. regulation or order promulgated or issued thereunder oy the state engineer. 41973 . p. 1719.)

445.354. Effective date of regulations and standards.

All rules, regulations and standards promulgated by the state commission of environmental protection and the state board of health pertaining to water pollution control in force on July 1, 1973. shall remain in effect until such time as revised by the state environmental commission pursuant to NRS 445.131 to 445.354 . inclusive. (1973, p. 1719.)

\section{Public Water Systems}

445.361. Declaration of state policy.

It is the policy of this state to provide for water which is safe for drinking and other domestic purposes and thereby promote the public health and weifare. (1977. p. 442.)

\subsection{Definitions.}

As used in NRS 445.361 to 445.399 . inciusive. unless the context otherwise requires. the terms defined in NRS 445.366 to 445.377 , inciusive. have the meanings ascribed to them in those sections. 11977, p. 443.)

\subsection{6. "Contaminant" defined.}

"Contaminant" means any physical. chemical, biological, radiological or other substance which can cause or transmit infectious disease. chemical poisoning, chronic disease or other impairment to man. (1977, p. 443.)

445.367. "Federal Act" defined.

"Federal Act" means the Safe Drinking Water Act (42 U.S.C. §§ 300 et seq.). (1977, p. 443.) 
445.369. "Heaith authority" defined.

"Heaith authority" means the officers and agents of the heaith division or the officers and agents of the local boards of heaith. 11977. p. 443.)

445.371. "Health division" defined.

"Health division" means the health division of the department of human resources. (1977, p. 443 .)

445.373. "Person" defined.

"Person" includes the State of Nevada. any political subdivision of this or another state. and any agency of the United States. 11977. p. 443.)

445.376. "Public water system" defined.

"Public water system" means any system which provides the public with piped water for human consumption if the system has 15 or more service connections or reguiariy serves 25 or more persons for 60 or more days a year. A public water system includes:

1. Any collection. treatment. storage and distribution facility under control of the operator of the system and used primarily in connection with the system; and

2. Any collection or pretreatment storage facility not under such control but used primarily in connection with the system. (1977, p. 443.)

LEGAL PERIODICALS

Review of Selected Nevada Legislation. Environmental Protection. 1985 Pac. LJ. Rev.

Nev. Legrs. 139.

445.377. "Suppiier of water" defined.

"Supplier of water" means a person who owns. controls or operates a public water system. (1977, p. 443.)

445.379. State board of health: Adoption of primary and secondary standards of drinking water.

The state board of health shall adopt by regulation:

1. Primary drinking water standards which prescribe the maximum permissible leveis for contaminants in any public water system and provide for the monitoring and reporting of water quality. In establishing the standards the board shail consider. among other things, the standards established pursuant to the Federal Act. 
2. Secondary drinking water standards winich reasonably insure that drinking water is aesthetically adequate. (1977. p. 443: 1981, p. 1900.)

445.381. State board of health: Regulations governing construction. operation and maintenance of public water systems; establishment of system for issuance of operating permits.

The state board of heaith may:

1. Adopt such regulations as may be necessary to govern the construction. operation and maintenance of public water systems if those activities affect the quality of water. but the regulations do not supersede any regulation of the public service commission of Nevada.

2. Establish by regulation a system for the issuance oi operating permits for suppliers of water and set a reasonable date after which a person shall not operate a public water system without possessing a permit issued by a health authority. (1977, p. 443: 1985 . p. 336.)

Efective date. - The 1985 amendment became effective Aprii 10. 1985.

445.383. State board of health: Contracts: assistance: hearings; subpenas.

To carry out the provisions and purposes of NRS 445.361 to 445.399 . inclusive, the state board of heaith may:

1. Through the state health officer and the administrator of the health division:

(a) Enter into agreements. contracts or cooperative arrangements with other state agencies. federai or interstate agencies. municipaiities, local heaith departments, educational institutions or other organizations or persons.

(b) Accept financial and technical assistance from the Federai Government, other public agencies or private contributors.

2. Hold hearings and issue subpenas requiring the attendance of witnesses and the production of evidence. 11977, p. 443; 1981, p. 82: 1983. p. 837.)

445.386. Review and approval of plans and specifications by health authority.

1. Except as provided in subsection 2, plans and specifications for any substantial addition to or alteration of a public water system subject to a regulation of the state board of health shall be submitted to the health authority for review and approval.

2. A public water system is not required to submit any plans and specifications if the addition or alteration complies with standards previously approved by a heaith authority. 
NEVADA ADMINISTRATION CODE 
4. "Health division" means the heatin dimsion ot the department of numan resources.

5. "Laboratory certuficauon officer" means the person approved by the Environmental Protection Agency to act as the laboratory certufication officer for this state.

6. "Primary ilandard" means a standard "hich ipecities a maximum contaminant levet for any constluent lound in a pubtic witer upply Which. if exceeded. mav adversely atfect the health of persons.

7 . "Secondary standard" means a standard which specifies a maximum level for constituents lound in a public water supply which. if exceeded, may adversely alfect the public welfare. These standards apply 10 constituents which adversely affect the laste. odor. appearance and other esthetic qualities of water.

8. "Surface vater" means water which is exposed to the atmosphere and subiect to suriace runoff.

9. The words and terms defined in t0 C.F.R. $\$ 1+1.2$ have the meanings ascribed to them in that section.

[Bd. of Health. Water Quality Standards Art. 1. elf. $12-1+-77 \mid--(1) A C A$ 5-23-90: 9-19-90: 12-3-90: 8-1-91)

\$45.245 Applicability. VAC $4+5.24+$ to $\$+5.262$. inclusive. apply to all public water systems unless a public water system:

1. Consists only of distribution and storage facilities and loes not have any coliection or treatment facilities:

2. Obtains all of its water from, but is not owned or operated by, a public water system to which NAC $\$ 45.244$ to $4+5.262$. inclusive. apply:

3. Does not sell water to any person: and

4. Is not a carrier which conveys passengers in interstate commerce.

[Bd. of Health. Water Quality Standards Art. 2 \$§ 2.3-2.3.1.4. eff. 12-14-77]

445.246 Construction.

1. Nothing contained in V.AC $+45.2+410+45.262$. inclusive. may be interpreted to circumvent any of those sections to make them less effectue.

2. If more than one interpretation exists for a section. the more restrictive interpretation applies.

[Bd. of Health. Water Quality Standards Art. $2 \S \S 2.2-2.2 .2$. eff. 12-14-77]

445.2\$7 Primary standards.

1. Except as otherwise provided in subsection 2. all public water systems must meet the requirements of NAC +45.244 to +45.262 . inclusive. and of the National Primary Drinking Water Regutations. as set forth in the July 1. 1991. edition of 40 C.F.R. $\$ \$ 1+1.1 .1+1.4,1+1.5 .1+1.11$ to $1+1.16$. inclusive. $1+1.61$. 141.62, $1+1.63 .1+1.100 .1+1.101 .1+1.110$ and $1+1.111$.

2. The effective date of the regulations contained in $\$ 1+1.61(c)(2),(3)$ and (4) is posiponed pursuant to National Primary Drinking Water Regulations: Aldicarb. Aldicarb Sulfoxide. and Aldicarb Sulfone. 57 Fed. Reg. 22178 (1992), until notice that the postponement has been cancelled is published in the Federal Register.

3. The National Primary Drinking Water Regulations. as set forth in the July 1. 1991. edition of to C.F.R. $\$ \$ 1+1.1,1+1.4 .1+1.5 .1+1.11$ to $1+1.16$. 
inclusive. $:+1.61 .: \div-62.1+1.63 .1+1.100$. $1+1.101 .:-1.100$ and $1+1.111$ are adopted by reterence. Copies of those regulanons $\mathrm{s}=$ wallable tor purchase from the otfice of the Health Division. 005 E. King Sireut. Room 10j. Carson Cily. Vievada 39:10. at a price of 57 eact.

i. Wherever the current Vational Primar! Drinking ivater Regulauons. as adopted in subsection 2. provide state discretion in estahlishing monitoring irequencies. check sampling requirements. Jetermination of compliance with maximuin contaminant levels, recordkeeping or nontication requirements. that discretion must be exercised by the heaith authority.

[Bd. of Health. Water Quality Standards Art. 3. eff. 12-14-77: A 5-3-31)--(NAC A 3-22-89: 12-3-90:7-16-92)

445.2475 Monitoring and analytical requirements for primary standards.

1. Except as otherwise provided in subsection 2. the activilies of monitoring and analytical requirements for the primary standards contained in $\mathrm{NAC}$ $\$+5.247$ must be performed as required by the Jul! 1.1991 . edition of 40 C.F.R. $\$ \$ 1+1.21$ to $1+1.30$. inclusive. and $1+1.40$ to $1+1 .+2$. inclusive. of the "Vational Primary Drinking Water Regulations."

2. Monitoring for the contammanis aldicarb. aldicarb sulfoxide and aldicarb sulfone must be conducted in accordance with the Jul! 1. 1991. edition of 40 C.F.R. \$ $1+1.40$ until the effectuve date of the regulations referred to in subsection 2 of NAC $\$+5.247$ is no longer postponed.

3. If the MMO-ivLG Test for total coliform detection is used. all total coliform-positive cultures must be tested for fluorescence. To test for fluorescence, an ultraviolet light ( 366 nanometers) must be used in the dark after incubating the tube or container at $35 \pm 0.5$ degrees Centigrade for 24 to I8 hours. If fluorescence is observed, the sample is Escherichia coli-positive. If fluorescence is not observed. a 0.1 milliliter 29 -hour culture must be transferred to Escherichia coli medium + MLG with a pipet. The results must be observed and the Escherichia coli medium - MLG must be formulated and incubated in the manner described in paragraph $(f)(6)(1)$ of the July 1. 1991. edition of 40 C.F.R. $\$ 1+1.21$.

4. For the purposes of this section. "MMO-ivLG Test" means a Minimal Medium ONPG-NIUG Test approved by the Linited States Environmental Protection Agency for tesung for the presence or absence of fecal coliform and Escherichia coli.

(Added to NAC by Bd. of Health, eff. 7-16-92)

45.248 Secondary standards: General requirements: public notice.

1. Whenever any of the following chemical subsiances. as measured at representative points in the distribution system. is present in a public water supply in excess of the listed levels. and the health authority determines that there is another more suitable supply of water which is economically feasible. available in a sutficient quantity. and of a significantly higher quality. the supplier of water shall give notice to the public: 
Substance

Chloride

Color

Copper

Foaming Agents

Iron

Magnesium

Manganese

Odor

$\mathrm{pH}$

Sulfaie

TDS (total residue bried at $103^{\circ} \cdot 105^{\circ} \mathrm{C}$ )
Level.

Villigrams

Per Liter

250.0

15.0 color units

1.0

0.5

0.3

125.0

0.05

3.0 threshold odor number

$6.5-5.5$

250.0

500.0

5.0

2. The following chemical substances. as measured at representative points in the distribution system. must not be present in a public "ater supply in excess of the listed levels:

Substance

Chloride

Iron

Magnesium

Manganese

Sulfate

TDS (total residue dried at $\left.103^{\circ} \cdot 105^{\circ} \mathrm{C}\right)$
Level.

Milligrams

Per Liter

400.0

0.6

150.0

0.1

500.0

1000.0

3. The standard for fluoride in community and nontransient. noncommunity water systems is 2.0 milligrams per liter.

4. If a public water system exceeds one of the standards set by subsection 2 or 3 or the state board of health grants a variance from the requirement concerning that contaminant level. the supplier of water shall give notice to the public.

5. The notices required by subsections 1 and + must be:

(a) Published in a neu spaper of general circulation in the area served by the system as soon as possible. but not more than 30 days after the standard is exceeded:

(b) Delivered personally or by mail to each person served by the system not more than +5 davs after the standard is exceeded: and 
(c) Pubiished and delivered annually thereatter as provided in this section it the siandard conunues to be exceeded.

lBd. of Health. Water Quality Standards Art $t$ ss +.1-t.2. elf. 12-14-77|--(:VAC + 3-22-39: 12-3-90)

\subsection{Secondary standards: Monitoring.}

i. Andiss lor dil public water sislems muse he completed hy Julle at. 1979. Anaiysis must be repeated at 3-vear intervals or at lesser intervals if required by the health authority.

2. If the result of an analysis made pursuant to subsection 1 indicates that the level of any contaminant listed in $V A C$ \$ $\$ 5.2+3$ exceeds the maximum level. the supplier of water must report to the health authority within 30 dats and initiate $j$ additional analyses at the same sampling point within 90 days. When the average of four anal!ses made pursuant to this subsection exceeds the maximum lesel. the supplier of water must notify the health authority and give notice to the public. Votice to the public must be in such form and manner as prescribed by the health authority and must ensure that the public using the sistem is adequately intormed.

3. Monitoring atter public notification must be at a trequency lesignated by the health authority and must continue until the level has not been exceeded in two successive samples or until a monitoring schedule as a condition 10 a variance or entorcement action becomes effective.

4. A supplier of water is not required to report results to the health authority where a state laboratory performs the analysis and reports the results to the health authority.

[Bd. of Health. Water Quality Standards Art. 4 $\S+.3-4.3 .3 .3$. eff. 12-1 --77]

445.250 Secondary standards: Analysis. Any analysis conducted to determine compliance with NAC +45.248 must be made in accordance with one of the following methods:

1. Any method listed in 40 C.F.R. Part 1+3. A copy of Part $1+3$ may be purchased from the Superintendent of Documents. L.S. Government Prinung Office. Washington. D.C. 20402. at a cost of $\$ 3.50$.

2. Any method published in any of the following standard reterence sources:

(a) Lnited States Environmental Protection Agency. E.MSL-Cincinnati. "Methods for Chemical Analysis of Water and Waste." EP.A-600/4-79-020. March 1979. and its revisions. aballable free of charge from ORD Publications. CERI. EPA. Cincinnati. Ohio +5265 .

(b) "Standard Methous tor the Examination of Water and Wasteuater." available from the American Public Health Association. 1015 Eighteenth Sireet N.W.. Washington. D.C. 20036. at a cost of 593.

(c) "Annual Book of ASTM Standards." volumes 11.01 and 11.02 . arailable from the American Society for Testung and Materials. 1916 Race Street. Philadelphia. Pennsvlvania 19103. at a cost of 558 and 582 . respectively.

(d) United States Geological Survey. "Methods for Determination of Inorganic Subsiances in Water and Fluviai Sedimenis." Book 5. stock number 024-001-03177-9. 1979 and its revisions. available for the cost of reproduction from the consumer health protection section of the bureau of regulatory health 
ervices of the health ivision. 50j East King Sireet. Rocm id: Curson Cit!. vevida 39710.

3. Any method approved by the Linited States Envioninental Protection Agency as an accepted alternauve lest procedure tor drinking water.

[Bd. of Health. Water Quality Standards Art $\div$ is -A-40. eff. $12-14-771-(\mathrm{NAC}+3-22-89)$

445.251 Conduct of analysis.

1. Except as provided in this section. each analysis regurred hy $\triangle A C$ $+45.2+7$ to $\$+5.250$. inclusive. must be pertormed by a properly certified laboratory.

2. For the purposes of this section. "properly certified laboratory" means a laboratory that is certified as acceptable by the laboratory certification officer in accordance with a certitication plan approved by the Environmental Protection Agency and regulations and procedures adopted b! the state board of health.

3. Turbidity measurements may be made by a certufied laboratory or by water supply personnel utlizing an instrument iapable of meeung the requirements of $\$ 1+1.22(a)$ of the "Vational Drinking Water Regulations." page 12 .

4. Chlorine residual measurements when authorized as a substitute for coliform bacteria monitoring may be made by the water suppiter utilizing an instrument and methods capable of meeting the requirements of $\$ 1+1.21(\mathrm{~h})$ of the "National Drinking Water Regulations," page 11.

[Bd. of Health. Water Quality Standards Art. 5, eff. 12-1--77]--(NAC A $3-22-89 ; 5-23-90)$

445.252 Methods of obtaining samples of water.

1. Samples of water taken for the purpose of a complete chemical analysis must be taken as provided in this section.

2. A sample taken for the purpose of analyzing levels of components not requiring preservation must be collected in a clean giass or piastic half-gallon or gallon container. A thoroughly rinsed plastic distilled water bottle or unused plastic milk bottle. obtamable at a dairy or a food or drug store. is recommended for this purpose.

3. A sample taken tor the purpose of analyzing levels of nitrates and metals must be collected in a container provided by the laboratory performing the analysis. using the approprate materials for preservation frovided by the laboratory. These materials may be added to the containers by the laboracory before the sample is taken. Care must be exercised in using such materials because of their hazardous nature.

4. A sample taken for the purpose of analyzing levels or trace organic materials must be laken in a glass container provided by the laboratory performing the analysis. The laboratory shall also provide any preservatues required for preventing deterioration of the organic materials.

5. If any representative sample is aken from a well for the purpose of chemical analysis:

(a) Except as provided in paragraph (b). an amount of water equivatent to four to ten times the bore volume of the well must be pumped from the well betore the sample is taken. 
40 CFR - PART 141 
tion 1412 of the Public Health Service Act. as amended by the Safe Drinkung Water Act (Pub. L. 93-523); and related regulations applicable to public water systems.

\section{\$141.2 Definitions.}

As used in this part. the term:

Act means the Public Health Service Act. as amended by the Safe Drinking Water Act. Pub. L. 93-523.

Action level is the concentration of lead or copper in water specified in $\$ 141.80(\mathrm{c})$ which determines. in some cases. the treatment requirements con tained in subpart I of this part that a water system is required to complete.

Best available technology or BAT means the best technology, treatment techniques. or other means wnich the Administrator finds. after examination for efficacy under field conditions and not solely under laboratory conditions are available (taking cost into consideration). For the purposes of setting MCLs for synthetic organic chemicais, any BAT must be at least as effective as granular activated carbon.

Cocoulation means a process using coaguiant chemicals and mixing by which colloidal and suspended materials are destabilized and agglomerated into nocs.

Community water system means a public water system which serves at least 15 service connections used by yesr-round residents or regularly serves at least 25 year-round residents.

Compliarce cycie means the nuneyear calendar year cycle durang which public water systems must monitor. Ench compliance cycie consists of three three-year compliance periods. The flrst criendar year cycle begins January 1, 1993 and ends December 31. 2001: the second becins January 1 . 2002 and ends December 31. 2010: the thtrd begins January 1, 2011 and ends December 31. 2018.

Compliance period means a threeyear calendar year period within a compllance cycle. Each compliance crole has three three-year compliance pertods. Within the flrst compliance crite. the first compliance period runs from January 1. 1993 to December 31. 1995: the second from January 1, 1996 to December 31. 1998: the third from January 1. 1999 to December 31. 2001.

Confluent growth means a continuous bacterial growith covering the enture filtration area of a memorane filter. or a portion thereof. in which bacterial colonies are not discrete.

Contaminant means any physical. chemical. biological. or radiological substance or matter in water.

Conventional filtration treatment means a series of processes including coagulation. flocculation. sedimenta. tion. and filtration resulting in sub. stantial particulate removal.

Corroszon inhibitor means a substance capable of reducing the corrosivity of water toward metal plumbing materials. especially lead and copper. by forming a protective film on the interior suriace of those materials.

CT or CTcalc is the produce of "residual disinfectant concentration" (C) in $\mathrm{mg} / \mathrm{l}$ determined before or at the first customer. and the corresponding "disinfectant contact time" (T) in minutes. i.e.. " $C$ " $x$ " $T$ ". If a public water system applies disinfectants at more than one point prior to the first cus. tomer, it must determine the CT of each disinfectant sequence before or at the first customer to determine the total percent inactivation or "total in. activation ratio." In determining the total inactivation ratio. the public water system must determine the residual disinfectant concentration of each disinfection sequence and corresponding contact time before any subsequent disinfection application point(s). "CTn." is the CT value required for 99.9 percent $\left(3-l_{0}\right)$ inact vation oi Giardia lamolia cysts. CTm. for a variety of disinfectants and conditions appear in Tables 1.1-1.6. 2.1. and 3.1 of $\$ 141.74(b)(3)$.

$$
\frac{\text { CTcale }}{\text { CTro. }}
$$

is the inactivation ratio. The sum of the inactivation ratios, or lotal inactivation ratio shown as

$$
\sum \frac{\text { (CTCaic) }}{\left(C T_{0.0)}\right)}
$$

is calculated by adding cogecher the inactivation ratio for each disinfection 
1963. U.S. Department of Commerce. If two or more radionuclides are present. the sum of their annual dose equivalent to the total body or to any organ shall not exceed \& millirem/ year.

Table a-Average annual Concentrations ASSUMEO TO PAOOUCE A TOTAL BOOY OR ORGAN DOSE OF A MAEM/YR

\begin{tabular}{|c|c|c|}
\hline Ascionicios & Critical organ & $\underset{\text { Xiter }}{x}$ \\
\hline $\begin{array}{l}\text { Tritiom } \\
\text { Strontum-90 }\end{array}$ & marrow & 20.000 \\
\hline
\end{tabular}

(41 FR 28404. July 9. 1976)

\section{Subpart C_Monitoring and Analytical Requirements}

\section{$\$ 141.21$ Collorm enmpling.}

(a) Routine monitoring. (1) Publlc water systems must collect total collform samples at sites which are representative of water throughout the distribution system according to a writ. ten sample siting plan. These plans are subject to State review and revision.

(2) The monitoring frequency for totel collforms for community water systems is based on the population served by the system. as follows:

\section{TOTAL COUFORM MONITORING FREOUENCY} FOR COMMUNITY WATER SYSTEMS

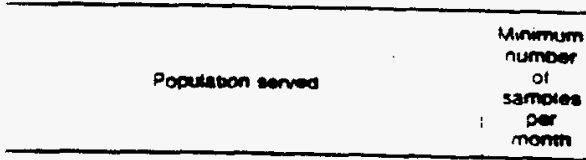

25 to 1.000 ,

1.001 to 2.500

2.501 to 3.300

3.301 to 4.100

4.101104 .900

4.901105 .800

5.901105 .800

5.801106 .700
6.701107 .600

6.701107 .600
7.601
8.508

B.501 to 12.900

12.801 to 17.200

17.201 to 21.500

21,501 to 25.000

25.001 to 33.000

33.001 to 41.000

$\$ 1.001$ to 50.000

50.001 to 59.000

59.001 to 70.000

70.001 to 83.000 .

83.001 to 96.000

3
3

TOTAL COLIFORM MONITORINO FREOUENCY FOA COMMUNITY WATER SYSTEMS-Continued

\begin{tabular}{|c|c|}
\hline Poputation samed & $\begin{array}{c}\text { Minimim } \\
\text { nimber } \\
\text { of } \\
\text { monemen }\end{array}$ \\
\hline
\end{tabular}

96.001 to 130.000

130.00110220 .000

220.001 to 320.000

320.001 10 450.000

$\$ 50.001$ to 600.000

500.001 to 780.000

-30001 to 970.000

;70.001 to 1230.000

230.001 to 1520.000

520.001 to 1850.000

950.001102 .270 .000

2.270 .001103 .020 .000

3.020 .001 to 3.960 .000

3.360 .001 or mare

(1)

100

$+20$

150

180

210
240

240
270

200

30

360

390

420

450
480

incluove oubve water sustem wruch have at lesen is

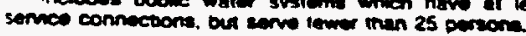

If a community water system serving 25 to 1,000 persons has no history of total coliform contamination in its current configuracion and a sanitary survey conducted in the past five years shows that the system is supplied solely by a protected groundwater source and is free of sanitary defects. the State may reduce the montoring irequency specified above, except that in no case may the State reduce the monitoring trequency to less than one sample per quarter. The State must approve the reauced montoring frequency in sriting.

(3) The montoring frequency for total collforms for non-community water systems is as follows:

(i) A non-communty water system using only ground water (except ground water under the direct influence of surface water. as defined in $\$ 141.2$ and serving 1.000 persons or fewer must monitor each calendar quarter that the system provides water to the publlc. except that the State may reduce this monitoring frequency. in writing. if a sanitary survey show's that the system is free of sanitary defects. Beginning June 29. 1994. the State cannot reduce the monitoring frequency for a non-community Fater system using only ground wister (except sround water under the direct influence of surface water. as defined in 141.2$)$ an fever to less 1 (ii) A nonuodine only Ground wates ence of surt: 141.2) and perwons durtr tor at the 85 sired commi specifted in section, excer this monitori for eny mont persons or $t$ reduce the 1 leas than onc ground water ence of su: $(8 \times 3)(i v)$ of $t$ :

(iii) A nonuxing surface must monito a 8 llkes sytem. as (ax2) of this number of pe

(iv) A nonuring sround inquence of in 141.2. frequency as Wuter syster rraph (a)(2) system must frequency be the State det winter is unds surface water

(4) The pl collect sampl vals through that a syster mater cexcept direct influet defined in 1 persons or fi quired samplt are taken fror

(5) A publt surface water the direct in: as defined it prictice filtr Subpart $E$ a sample near tlon each day source water. \& 141.74(b)(2). 

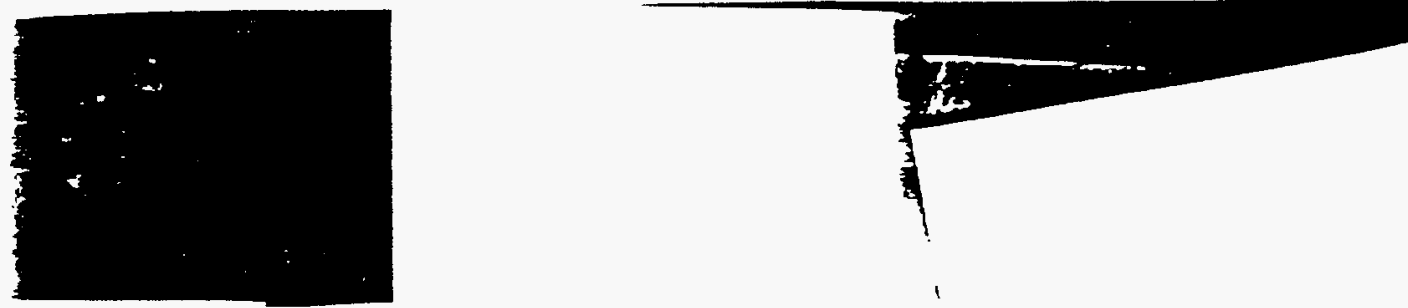

Edition)

EOUENCY

- iontinuea

\begin{tabular}{|c|}
\hline $\begin{array}{l}\text { Uinmmum } \\
\text { numoer } \\
\text { ot } \\
\text { samoues } \\
\text { ser } \\
\text { nonth }\end{array}$ \\
\hline$=0$ \\
\hline 20 \\
\hline$\leq 0$ \\
\hline 00 \\
\hline$=0$ \\
\hline$=: 0$ \\
\hline 0:" \\
\hline$\because 00$ \\
\hline 0: \\
\hline 00 \\
\hline :0 \\
\hline כ0: \\
\hline$\therefore 0$ \\
\hline O, \\
\hline
\end{tabular}

* al reast 15 erson:

I serving istory or

$n$ in its

sanitary

ive years

supplied

undwater

defects.

onitoring

sept that

duce the

than one

ite must

ring ire.

-nev tor

nmunity

r system

(except

sce influ-

ifined in

-rsons or

ralendar

provides

ihat the

Jung fre-

-y survey

of sant-

29. 1994.

monitor-

nmunity

ad water

ie direct

defined
Environmental Protection Agency

$\S 141.21$

in 141.2 and serving 1,000 persons or fewer to less than once/year.

(ii) A non-community water system using only ground water (except ground woter under the direct influ. ence of surface water. as defined in 141.2) and serving more than 1.000 persons during any monch must mon. tor at the same frequency as a likesized community water system. as specifted in paramraph $(a)(2)$ of this section. except the State may reduce this monitoring frequency. in writing. for any month the system serves 1.000 persons or fewer. The State cannor reduce the monitoring frequency to less than once/year. For systems using sround water under the direct intlu. ence of suriace water. paragrapn (a)(3)(iv) of this section appies.

(iii) A non-community water system using surface water. in total or in part. must monitor at the same frequency as a like-sized community water system. as specified in paragrapn (a)(2) of this section. regardless of the number of persons it serves.

(iv) A non-community water system using ground water under the direct influence of surface water, as defined in 141.2. must monitor at the same frequency as a like-sized community water system. as specifled in paragraph (a)(2) of this section. The system must begin monitoring at this frequency beginning six months aiter the State determines that the grouno water is under the direct influence ot surface water.

(4) The public diater system must collect samples at regutar time inter. vals throughout the month. except that a system which uses only ground water (except ground water under the direct influence of surface water. as defined in 141.2), and serves 4.900 persons or fewer. may collect all required samples on a single day if they are taken from different sites.

(5) A pubilc water system that uses surface water or ground water under the direct influence of surface water. as defined in 141.2. and does not practice filtration in compliance with Subpart $\mathrm{H}$ must collect at least one sample near the first service connection each day the turbidity level of the source water. measured as specified in $\$ 141.74(b)(2)$. exceeds 1 NTU. This sample must be anaiyzed for the presence of total coliforms. When one or more turbidity measurements in any day exceed 1 NTU. the system must collect this collform sample within 24 hours of the first exceedance. unless the State determines that the system. for logistical reasons outside the sysrem's control. cannot have the sample analyzed within 30 hours of collection. Sample results from this coliform monitoring must be included in determining compliance with the MCL for cotal coliforms in $\$ 141.63$.

6) Special purpose samples, such as those taken to determine whether dis. infection practices are suificient fol$\partial$ wng pipe placement. replacement. or repair. shall not be used to deter. mine compliance with the MCL for sotal coliforms in \$141.63. Repeac samples taken pursuant to paragraph (b) of this section are not considered special purpose samples, and must be used to determine compliance with the ACL for total coliforms in $\$ 141.63$.

(b) Repeal monitoring. (1) If a rou. tine sample is total coliform-positive. the public water system must collect a set of repeat samples within 24 hours of being notifled of the positive resuit. A system which collects more than one routine sarmple/month must colEect no fewer than three repeat sam. ples for each totad coliform-positive sample found. A system which collects one routine sample/month or fewer must collect no tewer than lour repear samples for eacn total coliform-posi$\because$ :re sample found. The State may axtend the 24-hour limit on a case-bycase basis if the system has a logistical problem in collecting the repeat samples within 24 hours that is beyond its control. In the case of an extension. the State must specify how much time the system has to collect the repeat samples.

(2) The system must collect at least one repeat sample from the sampling iap where the original total coliformpositive sample was taken. and at least one repeat sample at a tap within five service connections upstream and at least one repeat sample at a tap within ive service connections downstream of the original sampling site. If a total collform-positive sample is at the end of the distribution system. or one 
40 CFR Ch. I (7-1-91 Edition)

amination of Water and Wastewater may be obtained from the American Public Health Association et al.: 1015 Flfteenth Street. NW.: Washington. DC 20005. Coples of the methods set forth in Microbiological Methods for Monitoring the Environmenh Water and Wastes may be obtained from ORD Publications. U.S. EPA. $26 \mathrm{~W}$. Martin Luther KIng Drive. Cincinnati. Ohto 45268. Coples of the MMO-MUG Test as set forth in the article "Na. tional Field Evaluation of a Defined Substrace Method for the Simultaneous Enumeration of Total Collforms and Eschenchia coli from Drinking Water: Comparison with the Stanaara Multiple Tube Fermentation Method" (Edberg et al) may be obtained from the Amencan Water Works Associz. tion Research Foundation. 6666 West Quincy Avenue. Denver. CO 80235. Copies may be inspected at EPA's Drinking Water Docket: 401 M Street. SW.; Washington. DC 20460, or at the Office of the Federal Register: $1100 \mathrm{~L}$ Street. NW.: Room 8401: Washington. DC 20408.

(B) Response to violation. (1) A public water system which has exceeded the MCL for total coliforms in \$ 141.63 must report the violation to the State no later than the end of the next business day after it learns of the violation. and notify the public in accordance with 141.32 .

(2) A public water system which has iailed to comply with a coliform moni. :oring requrement. including the samtary survey requirement. must report the monitoring violation to the State within ten days after the system discovers the violation, and notify the public in accordance with \$ 141.32.

(54 FR 27582. June 29. 1989. as amended at 54 FR 30001. July 17. 1989: 55 FR 25084. June 19. 1990: 36 FR 642. Jan. 8. 1991]

\subsection{Turbidity sampling and analytical requirementa.}

The requirements in this section apply to unfiltered systems untll December 30, 1991, untess the State has determined prior to that date. in writing pursuant to section $1412(\mathrm{~b})(7)$ (1ii). that filtration is required. The requirements in this section apply to $f 1$ tered systems unt1l June 29. 1993. The requirements in this section apply to unfiltered systems that the State has determined. in writtng pursuant to section $1412(b)(7)(C)(111)$. must install fll. tration. untll June 29, 1993. or untll filtration is instslled. whichever is later.

(a) Bamples shall be taken by suppll. non-community water systems at a representative entry point(s) to the water distribution system at least once per day, for the purposes of making turbidity measurements to determine compliance with 8 141.13. If the State jetermines that a reduced sampling trequency in a non-community will not pose a risk to public health. it can educe the required sampling irequen. ty frequency shall be permitted only in those public water systems that practice disinfection and which main. tain an active residusl disinfectant in the distribution system. and in those cases where the State has indicated in writing that no unreasonable rist to health existed under the circum. stances of this option. The turbidity measurements shall be made by the Nephelometric Method in accordance with the recommendations set forth in "Standard Methods for Examination of Water and Wastewater." American Public Health Association, 14th Edllion. pp. 132-134: or "Methods of Chemical Analysis of Water and Wastes." EPA Environmental Monitoring and Support Laboratory. March :979. Method 180.1-Nephelometric Method. Callbration of the turbidimeter shall be made either by the use of a formazin standard as specifted in the cited references or a styrene divinylbenzene polymer standard (AmcoAEPA-1 Polymer, commercially avallable from Amco Standards Interna. tlonal. Inc. 230 Polaris Avenue. No. C. Mountain Vlew, Californta 94043.

(b) If the result of a turbidity analy. sis indicates that the maximum allow. able limit has been exceeded. the sam. pling and measurement shall be confirmed by resampling as soon as prac. ticable and preferably within one hour. If the repeat sample confirms that the maximum allowable limit has been exceeded. the supplier of water snall report to the State within 48

hours. The repeat sample shall be the ers of water for both community and cy. The option of reductng the turbidi.

\section{Environmontal Profectio}

sample used for the pu: lating the monthly as monthly average of the exceeds the maximum a or is the average of $t w 0$ on consecuttre days exc supplier of water shall State and notify the put in 181.31 and 141.32 .

(c) Sampling for $r$. water systems shall bef years after the effectiv parr.

(d) The requirements shall apply onily to pu: tems which use wace whole or in part from s

(e) The State has th determine compliance forcement action based cal resuits or other inf piled by their sanction tives and agencies.

[40 FR 59570. Dec. 24, 197: 45 FR 57344. Aug. 27.19 Mar. 3. 1982: $47 \mathrm{FR}$ 10998. FR 27527. June 29. 19891

8141.23 Inorganie chemic andrtical requirement

(a) Analyses for the termining compllance $w$ required as follows:

(1) Anaiyses for all co: systems utilizing surfact shail be completed with :owing the effective da. These anaiyses shall 1 yearly intervals.

(2) Anadyses for all co: systems utllizing only sources snall be comple years following the ef: this part. These analys pested at three-year int

(3) For non-commun tems. whether suppliec ground sources. analys shall be completed by 1980. These analyses sh at intervals determined

(4) The State has th. determine compliance forcement action basec cal results and other in pijed by their sanctior tives and agencies.

b) If the result of ar under parasraph (a) of 


\section{7-1-91 Edition !}

the State has ursuane to sec. nust install fil. 1993. or until whichever is

aken by suppiicommunity and systems ac a iount(s) to the in ai least once uses of making 3 to determine $\therefore$. If the State :uced sampling nunty will nor jealth. it can soling ireauen:ng the turoidipermitted ondy systems that id which masndisinfectant in 2. and in those las indicated in sonable risk to the circumThe turbidity made by the in accordance ons set forth in r Examination ter." American ion. 14th EdiMethoas or

Water and imental Montratory. Marcn Vephelometric :he turbidime. - by the use or ipecifled in the tyrene divinyl. ndard Amconercially avalldards InternaAvenue. No. C. 21894043.

urbidity analy. 3ximum allow. reded. the samc shall be con. s soon as prac. within one mple contirms $\therefore$ able limit has plier oi wacer ate within 48 :e shall be the
Environmental Protection Agency

$\S 141.23$

sample used for the purpose of calculating the monthly average. If the monthly average of the daily samples exceeds the maxumum allowable limit. or if the average of two samples taken on consecutive days exceeds $5 \mathrm{TU}$. the supplier of water shall report to the State and notify the public as directed in $\$ 141.31$ and 141.32 .

(c) Sampling for non-community water systems shall begin within two years after the eifective date of this part.

(d) The requirements of this 141.22 shall appiy only to public water sys. iems which use water obtainea in thole or in part from suriace sources.

e) The State nas the authority to determine compliance or inttiate en. forcemenc action basea upon analyti. cal results or other information com. piled by their sanctioned representatives and agencies.

(40 FR 59570. Dec. 24. 1975. as amended at 45 FR 57344. Aug. 27. 1980: 47 FR 8998 Mar. 3. 1982: 47 FR 10998. Mar. 12. 1982: 54 FR 27527. June 29. 1989)

814.23 Inorganic chemical sampiing and andytical requirements.

(a) Analyses for the purpose of determining compliance with $\$ 141.11$ are required as follows:

(1) Analyses for all community dacer systems utllizing suriace water sources shall be completed within one year 101 . lowing the effective date of this part. These analyses snall be repeated at yeariy intervais.

2) Analyses for all community water systems utilizing only ground water sources shall be completed within two years following the effective date of this part. These analyses shall be repented at three-year intervals.

(3) For non-community water systems, whether supplied by suriace or ground sources. analyses for nitrate shall be completed by December 24 . 1980. These analyses snall be repeated at intervals determined by the State.

(4) The State has the authority to determune compliance or initiate en. forcement action based upon analyti cal results and other information com piled by their sanctioned representatives and agencies.

(b) If the result of an analysis made under paragraph (a) of $(g)$ of this sec. :on indicates that the level of any contaminant listed in $\$ 141.11$ or 141.62 exceeds the maximum con iaminant level. the supplier of the rater shall report to the State within $i$ days and initiate three additional anaiyses at the same sampling point rithin one month.

(c) When the average of four anaiy. es made pursuant to paragraph (b) of his section. rounded to the same number of significant figures as the maximum contaminand level for the substance in question. exceeds the naximum contaminant level. the sup z:ter ot water snall notify the Stace sursuant to 141.31 and give notuce to $\therefore$ he public pursuant to $\$ 141.32$. Monicoring aiter public notification shall be at a frequency designated by the State and shall continue until the maximum contaminani level has not been exceeded in two successive samples or until a monitoring schedule as a condition to a variance. exemption or enforcement action shall become ef fective.

(d) The provisions of paragraphs (b) and (c) of this section notwithstanding. compliance with the maximum contaminant level for nitrate shail be determined on the basis of the mean i two analyses. When a level exceed. ing the maximum contaminant level or nitrate is tound a second analysis nail be iniliacea witnin 24 hours. ana $i$ the mean of the lwo analyses exceeds the maximum contaminant evel. the supplier of warer shall report his findings to the State pursu. ant to $\$ 141.31$ and shall notify the public pursuant to 141.32 .

(e) For the inttial anaiyses required by paragraph (a)(1), (2) or (3) of this jection. data for surface waters acquired within one year prior to the ef. ective date and data for ground vaters acquired within 3 years prior to the eifective date of this part may be substituted at the discretion of the State.

f) Analyses conducted to determine compliance with $\$ 141.11$ shall be made in accoraance with the following methods. or their equivalent as deter. mined by the Administrator. 


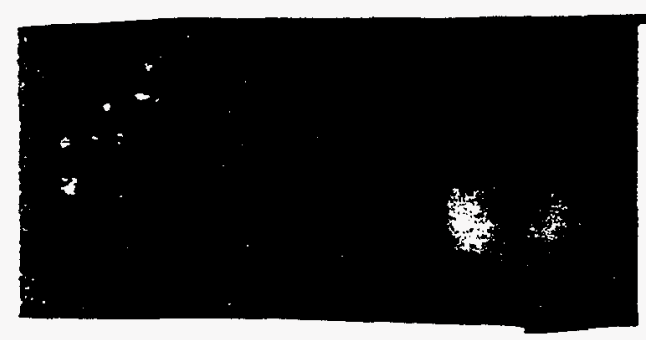

148-152. Atomic Absorption. Jiration: or Method + 239.2 . bsorption Furnace Tech. Method 200.7, Inductively iasms Technique.

;cury-Method' 245.1. or J-3223-79. or Method ' 301156-159. Manual Cold Vapor or Method' 245.2. Auto1 Vapor Technique.

rate-Method ' 352.1. or 3-992-71. or Method 2 419-D. 9. Colorimetric Brucine: or 353.3. or Method ' D-3867ethod 2 419-C. pp. 423-427. nc. Cadmium Reduction: 53.1. Automared Hydrazine or Method 353.2. or ;-3867-79A. or Method ' 605 .

4. Automated Cadmium Re.

slenium-Method ' 270.2 . bsorption Furnace Tech. Method ' 270.3; or Method 3 pp. 237-239. or Method 'D$r$ Method' 301-A VII. pD. iydride Generation-Atomic i Spectrophotometry.

iver-Method ' 272.1, or 01-A II. PD. 148-152, Atomic :-Direct Aspiration: or 272.2. Atomic Absorption zchniaue: or Method 200.7 .

Coupled Plasma Tech.

rde:

Sediments." Book 5. 1979. Stock :i7-8. Avallable from Superin. Documents. U.S. Government ce. Washineton. DC 20402.

30ok of ASTM Standards. part rerican Society for Testing and 376 Race Street. Phlladeiphia. 119103.

$\therefore$ di

eiy Coupled Plasma-Atomic ectrometic Method for Trace liysis of Water and Wastesi' zith Aopendix to Method .. "Inductively Coupled Plasma. :ssion Analysis of Drinteing in 1987. Ayallable from EPA's al Monitorng and Supporr :!ncinnati. Oh10 45268.

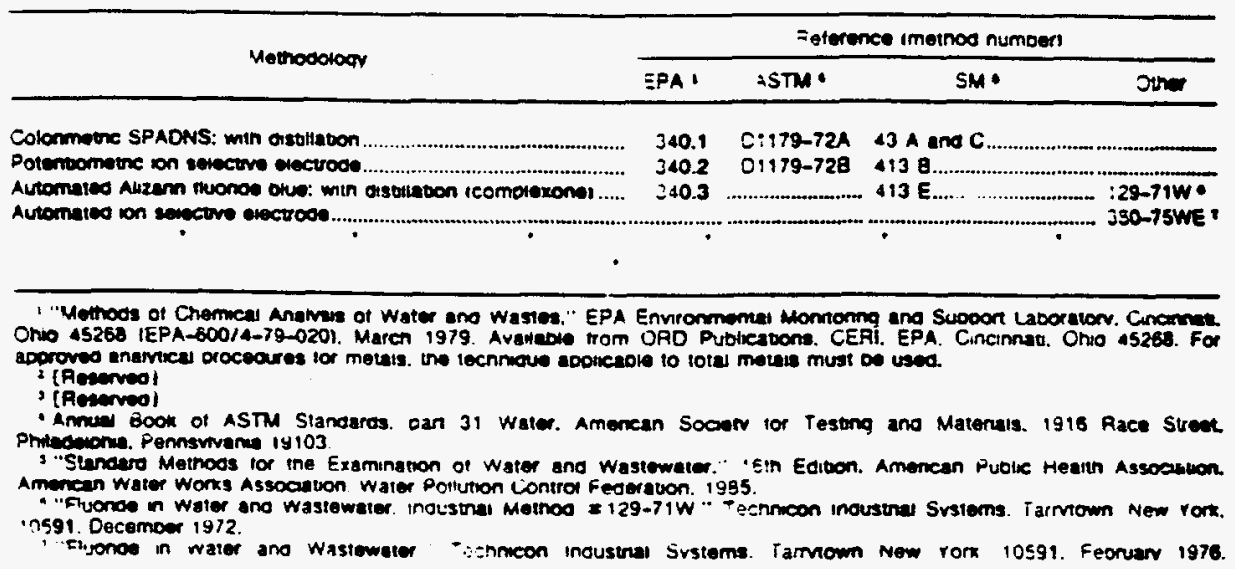

(g) Fluoride. In addition to complying wth paragrapts (a) through (f) of this section. systems montoring for fluoride must comply with the require. ments of this paragraphs.

(1)(1) Where the system draws water from one source, the system shall take one sample at the entry point to the distribution system.

(ii) Where the system draws water from more than one source. the system must sampie each source at the entry points to the distribution system.

(iil) If the system draws water from more than one source and sources are combined before distribution. the system must sample at an entry point to the distribution system auring periods representauve of the maxumum fluoride levels occurring unaer normal operating conditions.

(2) The state may alter the frequencies for fluoride monitoring as set out in paragraph (a) of this section to increase or decrease such frequency considering the following factors:

(i) Reported concentrations from prevtousty required monitoring.

(ii) The degree of variation in re ported concentrations and.

(III) Other factors which may affect nuoride concentrations such as changes in pumpung rates in ground water supplies or significant changes in the system's conifiruration. operat. ing procedures, source of water, and changes in stream ilows.

(3) Monitoring may be decreased from the frequencies specified in para. graph (a) of this section upon applica- tion in writing by water systems if the state determines that the system is unlikely to exceed the MCL. considering the factors listed in paragraph $(\mathrm{g})(2)$ of this section. Such determunation shall be made in writing and set forth the basis for the determination. A copy of the determination shall be provided to the Administrator. In no case shall monitoring be reduced to less than one sampie every 10 years. For systems monitoring once every 10 years. the state shall review the monioring resuits every ten years to determine whether more frequent monitoring is necessary.

(4) Analyses for fluoride under this section shall only be used for determining compliance if conaucted by iaboratories that have anaiyzed Performance Evaluation samples to xithin $=10 \%$ of the reference value at \{luoride concentrations from $1.0 \mathrm{mg} / \mathrm{l}$ to $10.0 \mathrm{mg} / \mathrm{l}$. within the last 12 months.

(5) Compliance with the MCL shall be determined based on each sampling point. If any sampling point is determuned to be out of compliance. the system is deemed to be out of compliance.

(40 FR 59570. Dec. 24. 1975. as amended at i5 FR 57344. Aug. 27. 1980: $47 \mathrm{FR} 10998$. Mar. 12. 1982: 51 FR 11410. ADr. 2. 1986: 51 FR 24329. Juily 3, 1986: 53 FR 5146. Feb. 19. [988]

Emfective Date Note 1: At 56 FR 3579. an 30. 1991. \$ 141.23 was revised. effective july 30, 1992. 


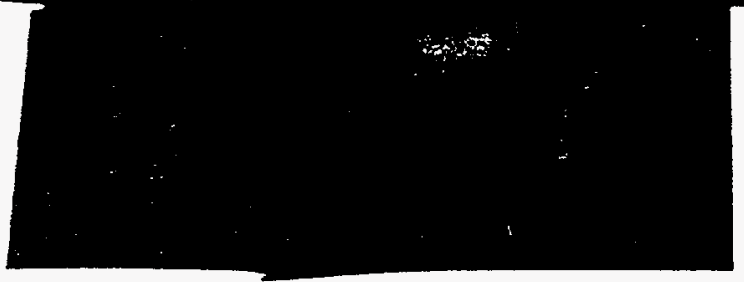

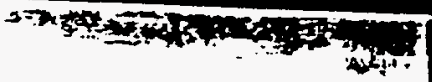

Envirenmental Protection Ageney

307A or Method I-i062-85. Atomic Ab. sorption-Gaseous Hydride: or Method. 206.4. or Method - D-2972-88A. or Method ${ }^{2}$ 3078. Spectropnotometnc. Silver Diethyldithlocaroamate: or Method - 200.7. Inductiveiy Coupled Plasma Technique.

(2) Barium-Method " 208.1 or Method 2 308. Alomic Absorption-Direct Aspiration: or Method ' 208.2. Atomic Absordtion Furnace Technique: or Method - 200.7. Inductively Coupled Plasma Technique.

(3) Camium-Method + 213.1 or Method - D 3557-78A or B. or Method 310A. Atomic Absorption-Direct Aspiration: or Method 213.2 Atomic Absorption Furnace $T$ ichnaque: or Method 200.7 . Inductuvery Coupledd Plasma rechnioue.

(4) Chromium-Method 218.1 or Method D 1687-77D. or Mechod 312A. Atomic Absorption-Direct Asoiration: or ChromiumMethod ' 218.2 Atomic Absorption Fumace Technique: or Method - 200.7. Inductively Couple Plasma Technique.

(5) Mercury-Method' 245.1. or Method D-3223-69. or Method 320A. Manual Cold Vapor Technique: or Method' 245.2. Automated Cold Vapor Technique.

(6) Nitrate-Method ' 352.1. or Method + D992-71. or Method' 353.3. or Method - D3887-79B. or Method 4 418-C. Spectrometrie. Cadmium Reduction: Method'353.1. Auromited Hydrazine Reduction: or Method 353.2. or Method D-3867-79A. or Method 418F. Automated Cadmium Reduction.

(7) Selenium-Method' 270.2. Atomic Ab sorption Furnace Technıque: or Method 270.3: or Method ' I-1667-85. or Method D3858-79. or Method +303F. Hydride Genera:ion-Atomic iosorption Ésectrodnoto. metry.

(8) Lead-Method 239.1 or Method D3559-78A or B. or Method ${ }^{2}$ 301-A II or III. po. 148-152. Atomic Absorotion-Direct As. piration: or Method ' 239.2. Atomic Absorptlon Fumace Technique: or Method - 200.7, Inductively Coupled Plasma Technique.

[56 FR 3579. Jan. 30. 1991. as amenced at 56 FR 30274. July 1, 1991]

- Annual Book of ASTM Standaras. part 31 Water. American Society for Testung and Matenais, 1976 Race Street. Philadelphia. Pennsyivamia 19103

s "Reserved].

- Inductuvely Coupled P!asma-Atomic Emission Soectrometric Method for Trace Element Analysis of Water and WastesMethod 200.7" with Appenoix to Method 200.7 entitled. "Inductively Coupted Plasme. Atomic Emission Analysis of Drinking Water." Maren 1987. Avaliable from EPA's Envtronmental Monitoring and Support Laboratory. Cincinnall. Ohio 45268.

\section{$\$ 141.24$}

\$141.24 Orzanic chemicals other than total trihalomethanes. sampling and anairtical requirements.

(a) An anaiysis of substances for the purpose of determining compliance with $\$ 141.12(a)$ and $141.12(b)$ shall be made as follows:

(1) For all community water systems utilizing surface water sources. analy. ses shail be completed within one year following the eifective date of this part. Samples anaiyzed shall be colected during the period of the year jesignated by the State as the period when contamination by pesticides is nost likely to occur. These anaiyses inall be repeaced at intervais specified by the State but in no event less frequently than at three year intervais.

(2) For community water systems utlliaing only ground water sources. analyses shall be completed by those systems specified by the State.

(3) The State has the auchority to determine compliance or initiate enforcement action based upon analytical results and other information com. piled by their sanctioned representatives and agencies.

(b) If the resuit of an anaiysis made pursuant to paragraph (a) of this section indicates that the level of any contaminant listed in 141.24 (a) and b) exceeds the maximum contamirant level. the supplier oi water shall report to the State within 7 days and initiate three additional anaiyses within one month.

(c) When the average of four analyses made pursuant to paragraph (b) of this section. rounded to the same number of simnificant figures as the maximum contaminant level for the substance in question. exceeds the maximum contaminant level. the suppiler of water shall report to the State pursuant to $\$ 141.31$ and give notice to the public pursuant to $\$ 141.32$. Monitoring after public notification shall be at a frequency designaced by the State and shall continue until the maximum contaminant level has not been exceeded in two successive sam. ples or until a monitoring schedule as a condition to a variance. exemption or enforcement action shall become ef lective. 


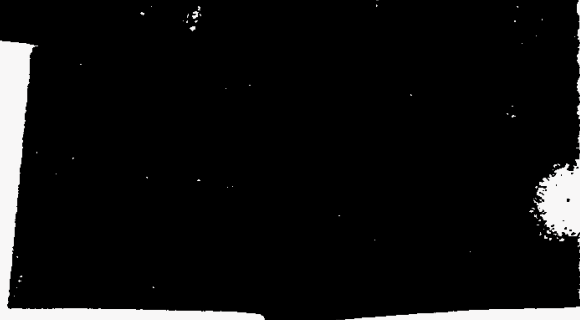

$\S 141.25$

\begin{tabular}{|c|c|}
\hline Contemment & $\begin{array}{c}\text { Setecoon umit } \\
\text { img/ili }\end{array}$ \\
\hline 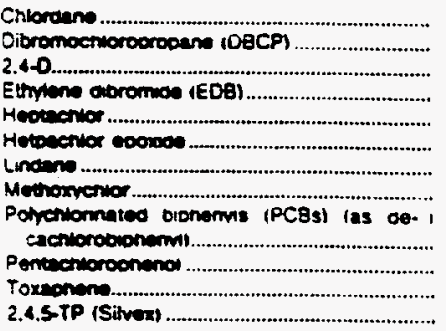 & $\begin{array}{l}2002 \\
20002 \\
2001 \\
20001 \\
20004 \\
20002 \\
20002 \\
2001 \\
\\
2001 \\
30004 \\
201 \\
2002\end{array}$ \\
\hline
\end{tabular}

(19) Anayists under this section snall oniv be conducted ov laboratories that nave pe. cetved certification ov EPA or the State and have met the following conations:

(i) To receive certification to conauct andyses for the contaminants in $141.61(\mathrm{c})$ the laboratory must:

(A) Analyze Performance Evaluacion sam. ples which include those substances provio. ed by EPA Environmental Monitoring ano Support Laborawry or equivalent samptes pronded by the State.

(B) Achleve quantitative resulus on the andiyses that are within the following acceptance limits:

\begin{tabular}{|c|c|}
\hline Contaminem & Acceotance umis toercent! \\
\hline 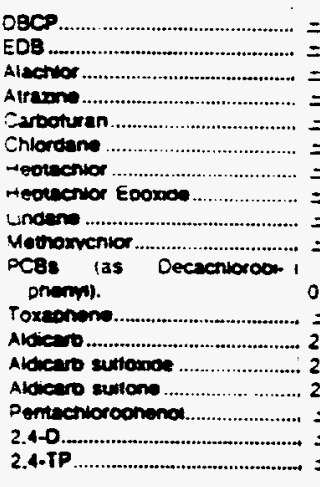 & $\begin{array}{l}=40 . \\
=40 . \\
=45 . \\
=45 . \\
=45 . \\
=45 . \\
=45 . \\
=45 . \\
=45 . \\
=45 . \\
0-200 . \\
=45 . \\
2 \text { standaro denations. } \\
2 \text { stancaro denaions. } \\
2 \text { standaro demaions. } \\
=\text { s0. } \\
=50 . \\
=\text { so. }\end{array}$ \\
\hline
\end{tabular}

(ii) [Reserved]

\$141.25 Analytical methods for radioactivity.

(a) The methods specufied in Interm Radlochemical Methodology for Drink. ing Water. Environmental Monitoring and Support Laboratory, EPA-600/475-008. USEPA. Cincinnati. Ohlo 45268. or those listed below. are to be used to determine compliance with
40 CFR Ch. I (7-1-91 Edition)

$\$ \$ 141.15$ and 141.16 (radioactivity) except in cases where alternative methods have been approved in ac cordance with \$ 141.27.

(1) Gross Alpha and Beta-Method 302 "Gross Alpha and Betg Radioacivity in Water" Slandard Methods for the Examination of Water and Wastewater, 13th Edition. American Public Health Association. New York. NY.. 1971.

(2) Total Radium-Method 304 'Radium in Water by Precipitation" Ibid.

3) Radium-226-Method ?05

Radium-226 by Radon in Water" Ibid.

(4) Strontium-89.90 - Method 303 Total Strontium and Strontium-90 in Water" Ibid.

(5) Tritium-Method 306 "Tritium in Water" Ibid.

(6) Cesium-134 - ASTM D-2459 "Gamma Spectrometry in Water." 1975 Annual Book of ASTM Standards. Water and Atmospheric Analysis. Part 31. American Society for Testing and Materials. Philadelohia. PA. (1975).

(7) Uranium-ASTM D-2907 "Microquantitles of Uranium in Water by Fluorometry." Ibid.

(b) When the identification and measurement of radionuciides other than those listed in paragraph (a) of this section is required. the following references are to be used. except in cases where alternative methods have been approved in accorcance aith \$ 141.27 .

(1) Procedures for Radiochemicai Analysis of Nuclear Reactor Aqueous Solutions. H. L. Krieger and S. Gold. EPA-R4-73-014. USEPA. Cincinnati. Ohio. May 1973.

(2) HASL Procedure Manual Edited by John H. Harley. HASL 300. ERDA Health and Safety Laboratory. New York. NY.. 1973.

(c) For the purpose of monitoring ra. dioactivity concentrations in drinking water. the required sensitivity of the radioanalysis is defined in terms of a detection limit. The detection limit shall be that concentration which can be counted with a precision of plus or minus 100 percent at the 95 percent confidence level $(1.96 \sigma$ where $\sigma$ is the standard deviation of the net counting rate of the samples.
Envirenmental 1

(1) To deter. 141.15 (a) the not exceed 1 pC pliance with \& iimit shall not $e$

(2) To deter 8141.16 the de exceed the co Table $B$.

TABLE B-DETEC BETA PARTICA

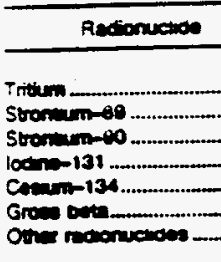

(d) To judg meximum cont 53141.15 and shill be used the same numi as the maximu the substance :

(e) The Stat determine con forcement act: cal resuits or piled by their tives and agen

[41 FR 28404. JL FR 57345. Aug.:

141.26 Monit, setivity in c

(a) Monito groses alpha $p$ 228 and radiur (1) Inittal compliance within two ye of these regu shall be comf of the effecti tlons. Compli the ansiysis 0 four consecut the average samples obta vale.

(1) A gross messurement the required 228 analysis 


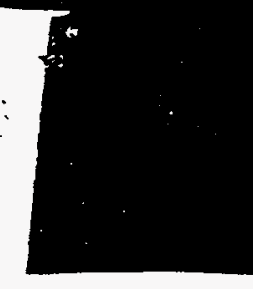

I (7-1-91 Edition)

.16 (radioactivity) where alternative $n$ approvea in ac27.

and Beta-Method and Beta Radioac. indard Methods for

of Water and Edition. American ciation. New York.

ium-Method 304

by Precipitation'

26-Method

Radon in Water

90 - irethoa 303 na Strontium-yo in

sod 306 "Tritium in

- ASTM D-2459 netry in Water." of ASTM Slandards. heric Analysis. Part ty for Testing and phia PA. (1975).

TM D-2907 "Microxium in Water by

identification and adionucindes ocher .n paragraph (a) of used. the following be used. except in ative methods have

accoraance with

for Radiocinemical ir Reactor Aqueous rieger and S. Gold. iSEPA. Cincinnati.

ure ManuaL Edited $\therefore$ HASL 300. ERDA

y Laboratory. New

ise of monitoring ra :rations in orinking d sensitivity of the fined in terms of a he detection limit intration wich can precision oi plus or at the 95 percent $.96 \sigma$ wnere $\sigma$ is the of the net counting

Environmental Protection Ageney

$\S 141.26$

(1) To determine compliance with $\$ 141.15(a)$ the detection limit shall not exceed $1 \mathrm{pCi} / 1$. To determine compllance with \$141.15(b) the detection limit shall not exceed $3 \mathrm{pCi} / 1$.

(2) To determine compliance with $\$ 141.16$ the detection limits snall not exceed the concentrations listed in Table B.

Table 8- Detection Limits for Man.made Beta Particle and Photon EmitTeas

\begin{tabular}{|c|c|}
\hline Andionucios & Zetection umit \\
\hline 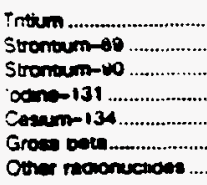 & 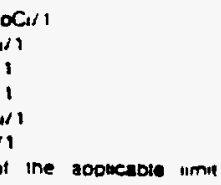 \\
\hline
\end{tabular}

(d) To judge compliance with the maximum contaminant levels listed in 11141.15 and 141.16. averages of data shall be used and shall be rounded to the same number of significant figures as the maximum contaminant level for the substance in question.

(e) The State has the authority to determine compliance or initiate en forcement action based upon analyti. cal resuits or other information com. piled by their sanctioned representa. tives and agencies.

(41 FR 28404. July 9. 1976. as amended at 45 FR 57345. Aur. 27. 19801

\$141.26 Monitoring irequency ior ragioactivity in community water systems.

(a) Monitoring requirements for 8700 alphs particle activity, radium228 and radium-228.

(1) Initial sampling to determine compliance with $\$ 141.15$ shall begin within two years of the effective date of these regulations and the anaysis shnll be completed within three years of the effective date of these regula. tions. Compliance shall be based on the analysis of an annual composite of four consecutive quarterly samples or the average of the anajyses of four samples obtained at quarterly inter vale.

(1) A gross alpha particle activity measurement may be substututed for the required radium-226 and radium228 analysis Provzded. That the meas. ured gross alpha particle activity does not exceed $5 \mathrm{pCi} / 1$ at a confidence level of 95 percent $(1.65 \sigma$ where $\sigma$ is the standard deviation of the net counting rate of the sample). In localities where radium-228 may be present in drinking water. it is recommended that the State require radium-226 and/or radium-228 analyses when the gross alpha particle activity exceeds 2 pCl/1.

(ii) When the gross alpha particle activity exceeds $5 \mathrm{pCi} / 1$. the same or an equivatent sample shall be anaiyzed for radium-226. If the concentration of radium-226 exceeds $3 \mathrm{pCi} / 1$ the same or an equivalent sampie shall be analyzed for radium-228.

(2) For the intial analysis requireo by parastapn $(a)(1)$ of this section. date acquired within one year prior to the effective date of this part may be substituted at the discretion of the State.

3) Suppliers of water shall monitor at least once every four years follow. ing the procedure required by para. graph ( $2 \times 1)$ of this section. At the discretion of the State, when an annua record taken in conformance with paragraph (a) (1) of this section has established that the average annual con centration is less than half the maximum contaminant levels established by 141.15. analysis of a single sample may be substituted for the quarterty sampling procedure required by para. graph $(a)(1)$ of this section.

i) More trequent monitoring snall be conducted when ordered by the State in the vicinity of minung or other operations which may contribute alpha particle radioactivity to either surface or ground water sources of drinking water.

(ii) A supplier of water shall monucor in conformance with paragraph (a)(1) of this section within one year of the introduction ot a new water source for a community water system. More irequent monitoring shail be conducted when ordered by the State in the event of possible contamination or when changes in the distribution system or treatment processing occur which may increase the concentration of radioactivity in finished water.

iii) A community water system using two or more sources having dif- 


\section{T-1-91 Edition)}

red to sdentify constituents -rate organ and e calculated to ith $\$ 1416$. - shall conauct as ordered by the concentraictivity in prinnated by the

of the State. atilizing ony e required to zaioactivity.

alvsis reouireo : this section e year prior to is part may oe cretion of the

lalysis required it this section ill monitor at

following the graph (b)( 1 ) of

of the effective ns the suppiter ir system desig. utilizing waters nts from nucle. iate quarterly - ca particle ana $y$ and annual m-90 ana triti.

ring lor gross all be Dasea on :ly samples or posite of three

iormer is rec. is beta particle ceeds $15 \mathrm{pCi} / 1$. ne sampie shall intium-89 ano is beta particle : 1. an analysis a periormed to zdioactive conhe appropriate doses shall be ne compliance

: composite or imples snall be uarter. As or nore frequent naucted when

\section{Environmental Protection Agency}

$\S 141.30$

iodine-131 is identified in the finished wster.

(iii) Annual monitoring for stronti. um-90 and trittum shall be conducted by means of the analysis of a compos. ite of four consecutuve quarterly samples or analysis of four quarteriy sample. The latter procedure is recom. mended.

(iv) The state may allow the substi. tution of environmental survellance date taken in conjunction with a nuclear facility for direct monitoring of manmade radioactivity by the suppuer of water where the State determines such data is applicable to a particular community water system.

(5) If the average annual maximum contaminant levei for man-made rado. activity set forth in $\$ 141.16$ is exceed. ed. the operator of a community water system shall give notice to the State pursuant to 141.31 and to the public as required by \& 141.32. Monitoring at monthly intervais shall be continued untl the concentration no longer ex ceeds the maximum contaminant level or untll a monitoring schedule as a condition to a variance. exemption or enforcement action snall become ef. fective.

[41 FR 28404. July 9, 1976]

\$ 141.27 Alternate anaivical techniques.

(a) With the written permission of the State. concurred in bv the Admin. istrator of the U.S. EPA. an alternate analytical technique may be employed. An alternate technique snall be ac. cepted only if it is substantially equivalent to the prescribed test in both precision and accuracy as it relates to the determination of compliance with any MCL. The use of the alternate an. alytical technique shall not decrease the frequency of montoring required by this part.

[45 FR 57345. Aug. 27, 1980 ]

\section{\$ 141.28 Approved laboratories.}

(a) For the purpose of determining compliance with $\S \hat{141.21}$ througn 141.27, 141.41 and 141.42. samples may be considered only if they have been analyzed by a laboratory approved by the State except that measurements for turbldity. free chlorine residual. temperature and $\mathrm{pH}$ may be per-
Sormed by any person acceptable to the State.

b) Nothing in this part shall be construed to preciude the State or any duly designated representative of the State from taking samples or from using the results from such samples to cetermine compliance by a supplier of water with the applicable requirenents of this part.

ड5 FR 57345. Aug. 27, 1980: 47 FR 10999. :־ar. 12. 1982]

1 11.29 Monitoring of consecutive public water svstems.

When a public water system supplies ater to one or more other public ater systems. the State may modify se monitoring requirements imposed $3 y$ this part to the extent that the interconnection of the systems jusifies reating them as a single system for monitoring purposes. Any modified monitoring shail be conducted pursuant to a schedule specified by the State and concurred in by the Administrator of the U.S. Environmental Protection Agency.

\$141.30 Total trihslomethanes sampline. anaiytical and other requirements.

a) Communty water system which erve a population of 10.000 or more ndividuals and which add a disinfect. nt (oxidant) to the water in any part $\therefore$ the drinking water treatment proc:s shall analyze lor total trihalometh. ines in accordance with this section. For systems serving $\mathbf{7 5 . 0 0 0}$ or more $\mathrm{in}$ lividuals. sampling and analyses shall begin not later than 1 year after the late of promulgation of this reguia. ion. For systems serving 10.000 to i 4.999 individuals. sampling and analy. ses shall begin not later than 3 years after the date of promulgation of this regulation. For the purpose of this sec:ion. the minimum number of samples required to be taken by the system nall be based on the number of treatnent plants used by the system. sxcept that multiple wells drawing raw water from a single aquifer may. ith the State approval. be considered one treatment plant for determining - he minimum number of samples. All amples taken within an established 
APPENDIX C

TRITIUM ANALYTICAL METHODS

C-1 


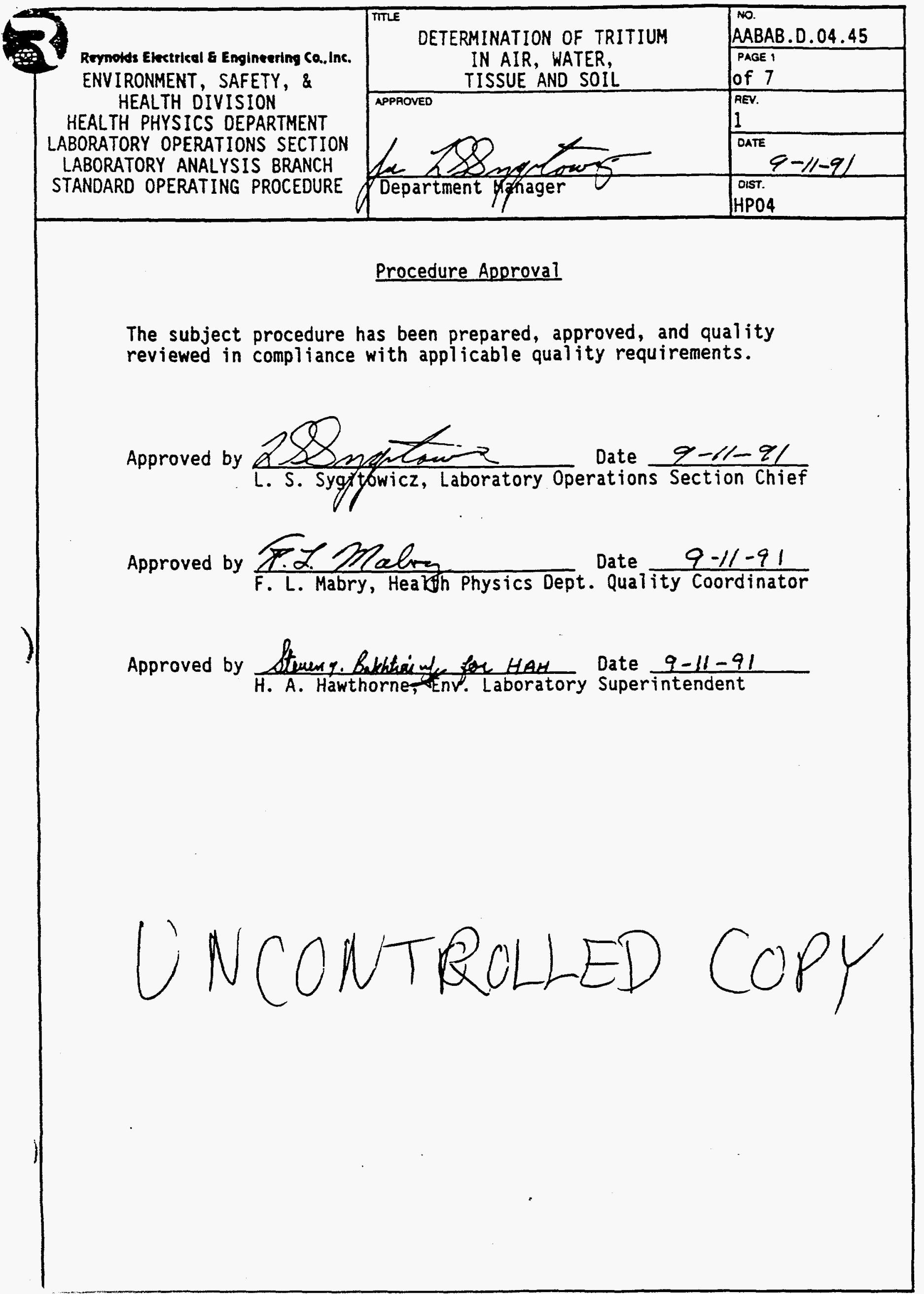




\section{FILING INSTRUCTIONS}

This procedure should be filed under Analytical Chemistry Methods in the "Laboratory Analysis Branch Standard Operating Procedures" binder. It supersedes Revision 0 dated May 29, 1990. Underlining marks the major changes in this procedure.

\section{PURPOSE}

This procedure describes the preparation of air, water, tissue and soit samples for tritium counting.

\section{RESPONSIBILITY}

The certified Radiochemistry Laboratory Technicians are responsible for preparing air, water, tissue and soil samples for tritium counting.

IV. REFERENCES

A. AABAB.D.04.10, "Determination of Plutonium in Water, Urine, Soil, and Biologicai Tissue."

B. "REECO ESD Laboratory Operations Radioanalytical Laboratory Procedures," September 1985.

\section{PRINCIPLE}

A portion of the sample is distilled to remove contaminants and minimize interfering quenching. Several different techniques are used to recover a pure distilled fraction. These techniques include azeotropic distillation, vacuum distiliation, and ambient pressure distillation. Details of these techniques will be discussed under procedure sections. After distillation, an aliquot is mixed with liquid scintillation solution and counted in a liquid scintillation spectrometer. Standards and background samples are prepared and counted with each group of samples.

\section{APPLICABILITY}

This is applicable for the determination of tritium in air, water, animal tissue, blood, and urine.

\section{INTERFERENCES}

A. Volatile radionuclides are the most common interferences. Alcohols, acids, ketones, and most $\mathrm{OH}$-radicals and hydrocarbons are common chemical interferences, but all may be eliminated by proper and careful sample preparation. 


\section{INTERFERENCES (Continued)}

B. Light and chemical phosphorescence must be considered. This can be eliminated by allowing the sample to dark-adapt for at least two hours. Electrostatic charges built up on the outside of the plastic sample vials may produce seriousiy erratic counting results. Electrostatic charges can be eliminated by using the built-in static eliminator and/or wiping the vials with an antistatic cloth or fabric softener.

\section{PRECISION AND ACCURACY}

Internal samples have indicated a precision of better than $5 \%$.

Reference materials have been analyzed on a routine basis and resuits have been obtained that were better than $5 \%$.

IX. SHIPMENT AND STORAGE OF SAMPLES

Water samples should be collected and stored in giass bottles with no preservatives. Biological samples should be kept refrigerated until ready for analysis.

\section{REAGENTS}

A. Cyclohexane: reagent grade.

B. Liquid scintillation solution: Beckman Ready-Safe ${ }^{T M^{*}}$.

C. Silver nitrate, crystals: reagent grade.

\section{APPARATUS AND MATERIALS}

A. Flask, boiling, 1 neck: $500-\mathrm{mL}$

B. Distilling receivers, Modified Dean-Stark: $10-\mathrm{mL}$ and $25-\mathrm{mL}$

C. Glas-Col heating mantle and insulating ponchos.

D. Desiccator, vacuum

E. Trap, Johns

F. Tube, connecting: 105-degrees, and 75-degrees

G. Vacuum pump

H. Liquid nitrogen 
XII. PRECAUTIONS

Technicians should wear gloves and work under the ventilated hood.

\section{METHODS}

\section{A. Water and Urine}

1. About $30 \mathrm{~mL}$ of sample are poured into a $500-\mathrm{mL}$ round bottom flask. Load the flask into the Glas-Col heating mantie in the exhaust hood with the exhaust fan on. All urine samples should be handled only with gloves and under the ventilated hood.

2. Mount the insulating metal poncho on top of the flask and turn the heating switch to a setting of 3 . Vent the first steam (approximateiy for 2 minutes) and collect the distillate in a distilling receiver. If radioiodine is present, add $0.1 \mathrm{~g}$ silver nitrate before distilling.

3. When $5.0 \mathrm{~mL}$ of distiliate are collected, turn off the heat and wait for the distillate to cool down to room temperature. The total amount of distillate collected should be more than 5.0 $\mathrm{mL}$.

4. Pipet a 5-mL portion of the distillate into a polyethylene counting vial. Add $14 \mathrm{~mL}$ of the liquid scintillation solution and shake well to mix the sample with the liquid scintillation solution. Label the cap of the vial with the sample number, sample type and event code.

5. Prepare a background sample by pipetting $5.0 \mathrm{~mL}$ of distilled low-tritium background water into a polyethylene counting vial and mixing well with $14 \mathrm{~mL}$ of liquid scintillation solution. Prepare a standard in the same way using $5.0 \mathrm{~mL}$ of a National Institute of Standards and Technology traceable tritium standard solution.

6. Load the samples in the sample changer of the Beckman LS 5801 Liquid Scintillation Spectrometer. Allow to dark-adapt for at least two hours. Count for two 35-minute intervals or until successive counts are within 2 sigma of 0.10 :

B. Air

The Laboratory usually uses silica gel and/or Drierite columns to collect tritiated water vapor in air.

1. Check the weight of the water collected. A minimum of 7 to 8 grams of water is needed for distillation. If a lesser amount is collected, add distilled low-tritium background water to make up a total water weight of $8 \mathrm{~g}$. Record the weight of the added water for use in calculating the activity of the air sample later. 


\begin{tabular}{|llll|}
\hline NO $A A B A B .0 .04 .45$ & REV 1 & DATED: $9 / 11 / 91$ & PAGE: 5 of 7 \\
\hline
\end{tabular}

METHODS (Continued)

2. Make sure the hood exhaust fan is on. Use a funnel to transfer the Drierite or silica gel into a $500-\mathrm{mL}$ round bottom flask. Heat to $300^{\circ} \mathrm{C}$ (heating setting at 5 to 6 ).

3. Collect the water in a modified Dean-Stark distilling receiver.

4. Proceed as in XIII.A.3-6.

C. Soil

1. Weigh out a $1 \mathrm{~g}$ sample on a glass watch-giass. Dry in an oven at $105^{\circ} \mathrm{C}$ overnight. Reweigh and determine the fractional water content of the soil.

2. Weigh out an appropriate amount of soil sample in a $500-\mathrm{mL}$ round bottom flask. Record the weight and add $10 \mathrm{~mL}$ of distilled low-tritium background water to soak up the soil (more water may be needed if larger amount of soil is used). Seal the flask with a rubber stopper and let stand for about an hour.

3. Make sure the hood ventilation is on. Proceed as in XIII.A.26.

D. Milk and Blood

1. Turn on the ventilation fan of the exhaust hood. Add $50 \mathrm{~mL}$ of sample and $50 \mathrm{~mL}$ cyclohexane to a $500 \mathrm{~mL}$ round bottom flask. Load the flask on the heating mantle. Mount the insulating poncho on top of the flask. Put on the $25-\mathrm{mL}$ distilling receiver. Distill at low heat until 6 to $7 \mathrm{~mL}$ of water are collected. Allow the distillate to cool and the phases to separate.

2. Carefully withdraw $5.0 \mathrm{~mL}$ of the water phase with a $5-\mathrm{mL}$ disposable pipet. Wipe off any cyciohexane on the outside wall of the pipet before dispensing the water into the scintillation vial. Proceed as in XIII.A.4-6.

E. Vegetation or Animal Tissue

1. Weigh 100 to $200 \mathrm{~g}$ of vegetable material or 25 to $50 \mathrm{~g}$ of animal tissue, place in a vacuum desiccator, and record the weight. Cool the trap with liquid nitrogen and apply a vacuum.

2. Allow vacuum distillation to continue for several hours until all of the water content is extracted. Heigh the amount of water collected and determine the fractional water composition.

3. Proceed as in XIII.A.4-6, above. 
XIV. QUALITY CONTROL

A background and a NIST-traceable standard are counted along with each group of not more than ten field samples. The background counts and efficiency of the instrument are recorded on a daily basis in the Instrument Logbook to provide an indication of the instrument performance.

Tritium spike samples are prepared from a NIST-traceable tritiated water standard and stored by the QA Unit. The H-3 activity of the spiked samples is in the range of several hundred picocuries per milliliter. A set of two spiked samples is issued twice a week along with routine field samples for tritium analysis. Every tenth urine sample and every contaminated waste pond water sample are split as duplicates. QC samples are issued by the Sample Preparation Technician following the procedure outlined in Reference $A, X V . B$. QC charts are prepared and QC data are reviewed as described in Reference $A, X V . C$.

XV. CALCULATIONS

A. Water, Urine, Milk, and Blood

$$
\text { Tritium }(\mu \mathrm{Ci} / \mathrm{mL})=\frac{C P M(S)-C P M(B K G)}{2.22 \times 10^{6} \cdot E \cdot V}
$$

where,

$$
\begin{aligned}
\operatorname{CPM}(S)= & \text { Gross counts per minute of the sample } \\
\operatorname{CPM}(B K G)= & \begin{array}{l}
\text { Gross counts per minute of the } \\
\text { background }
\end{array} \\
E= & \begin{array}{l}
\text { Fractional efficiency determined with } \\
\text { the standard counted with the sample } \\
\text { group }
\end{array} \\
V= & \text { Sample size in } \mathrm{mL}(\mathrm{e} . \mathrm{g} .5 \mathrm{~mL})
\end{aligned}
$$

B. Air

$$
\text { Tritium }\left(\mu \mathrm{Ci} / \mathrm{m}^{3}\right)=\text { Tritium }(\mu \mathrm{Ci} / \mathrm{mL}) \times \frac{\text { q of water }}{\mathrm{m}^{3} \text { of air }}
$$

where,

$$
\begin{aligned}
\text { Tritium }(\mu \mathrm{Ci} / \mathrm{mL})= & H-3 \text { activity of the sample counted } \\
\mathrm{g} \text { of water }= & \begin{array}{l}
\text { Amount of water collected }+ \text { any } \\
\text { amount of water added before } \\
\text { distillation }
\end{array} \\
\mathrm{m}^{3} \text { of air }= & \begin{array}{l}
\text { Total volume of air passing through } \\
\text { the column in } \mathrm{m}^{3}
\end{array}
\end{aligned}
$$


CALCULATIONS (Continued)

C. Soil

$\operatorname{Tritium}(\mu \mathrm{Ci} / \mathrm{g})=\operatorname{Tritium}(\mu \mathrm{Ci} / \mathrm{mL}) \times \frac{W+(\mathrm{F} \cdot \mathrm{S})}{S}$ where,

Tritium $(\mu \mathrm{Ci} / \mathrm{mL})=\mathrm{H}-3$ activity of the sample counted

$S=$ Weight of soil samples in $\mathrm{g}$ used for distillation

$W=$ Amount of water in $g$ added before distillation

$F=$ Fractional water composition of the soil

D. Vegetation and Animal Tissue

$\operatorname{Tritium}(\mu \mathrm{Ci} / \mathrm{g})=F \times \operatorname{Tritium}(\mu \mathrm{Ci} / \mathrm{mL})$

where,

$F=$ Fractional water composition $(\mathrm{mL} / \mathrm{g})$

XVI. GLASSWARE CLEAN-UP

A. Wash and rinse all glassware thoroughly with hot water. If dirt or residue is found inside a flask, wash with a $50 / 50$ (by volume) $\mathrm{HCl}$ solution or shake with small pieces of wet sand gravel inside the flask until the dirts and/or residue are removed.

B. After thoroughly rinsing with warm water, wash the glassware two or three times with distilled water squirted from a wash bottle. Rinse the inside of glassware with an approximately $1: 10$ acetone/ethanol mixture.

C. Place the glassware in a metal pan and dry in a drying oven at $200^{\circ} \mathrm{F}$ until completely dry. 


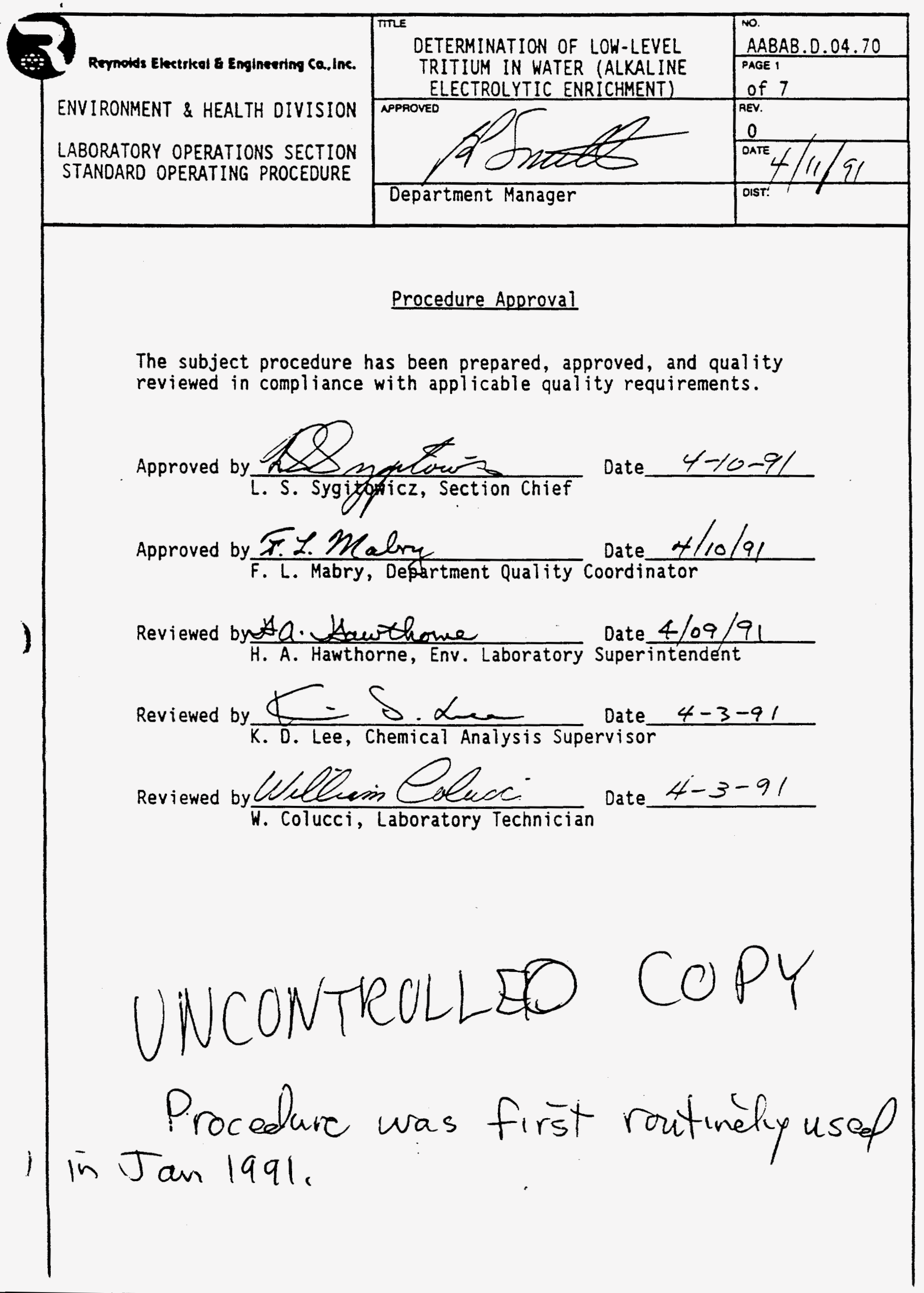




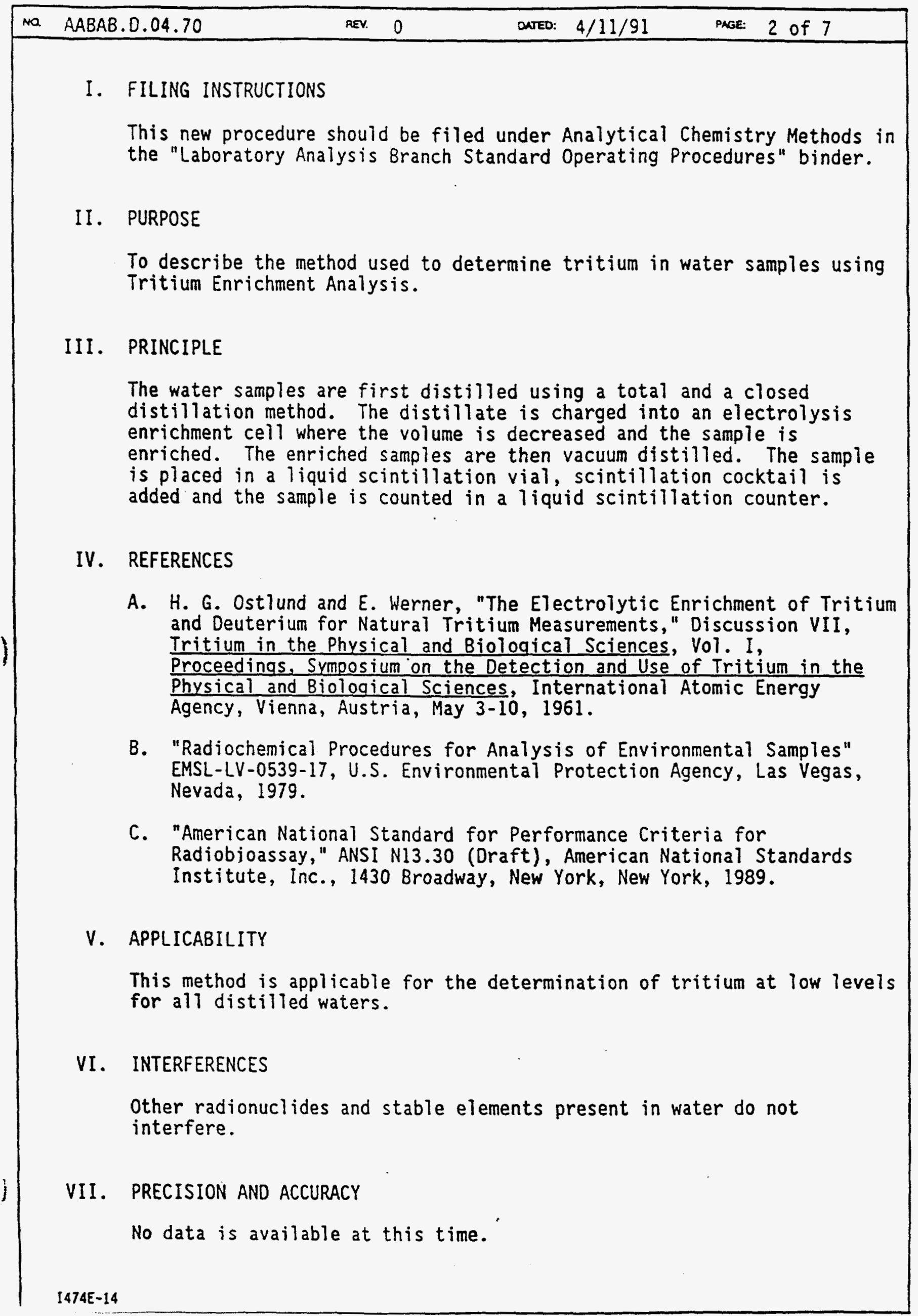




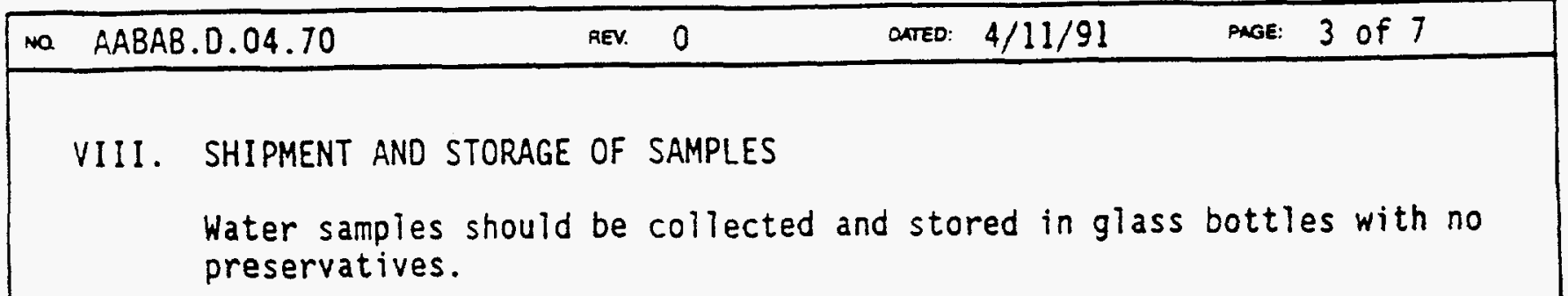

\section{REAGENTS}
A. Sodium hydroxide, pellets, reagent grade
B. Potassium permanganate crystals, reagent grade
C. Carbon dioxide, gas, commercial grade
D. Liquid nitrogen, commercial grade
E. Hydrochioric acid, $6 \mathrm{~N}$
F. Scintillation cocktail solution, Packard, "Pico-Fluor LLT"
G. Ethyl alcohol, reagent grade
H. Ethylene glycol, commercial grade
I. $0 i 1$, vacuum pump

\section{APPARATUS AND MATERIALS}

A. Balance, analytical

B. Bottle, $500 \mathrm{~mL}$ screw cap

C. Chips, boiling: Teflon

D. Condenser, Liebig $300 \mathrm{~mm}$

E. Constant current supply 3 amp and 0.3 amp are required.

F. Constant temperature bath

G. Distillation column, Snyder

H. Electrolytic cell, $160 \mathrm{~mL}$

I. Flask, round bottom: $1000 \mathrm{~mL}$

J. Flask, volumetric: $250 \mathrm{~mL}$

K. Glass, fiber: 8 micron

L. Mantle, heating: $1000 \mathrm{~mL}$

M. Oven, drying

N. Oven, heating 


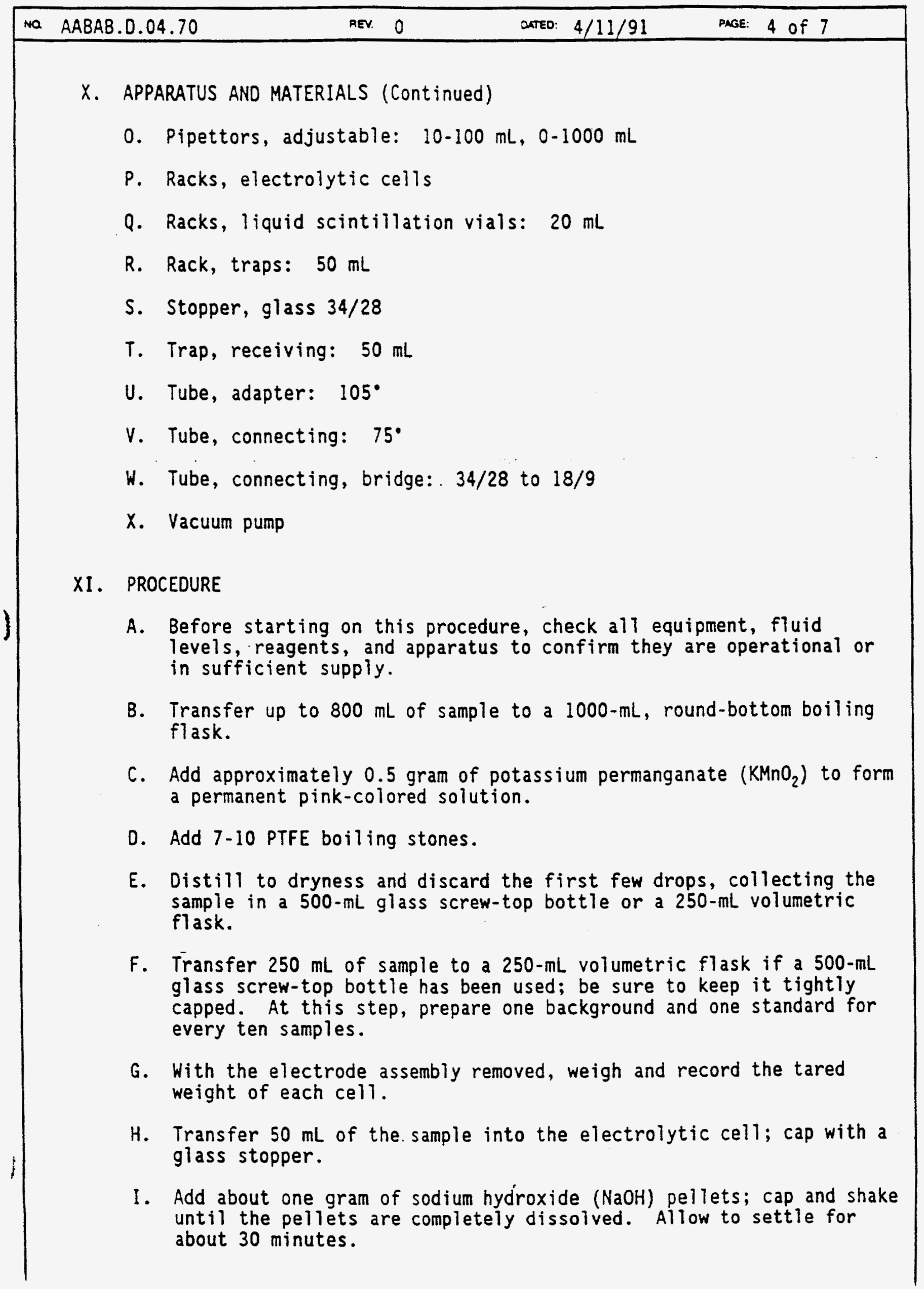




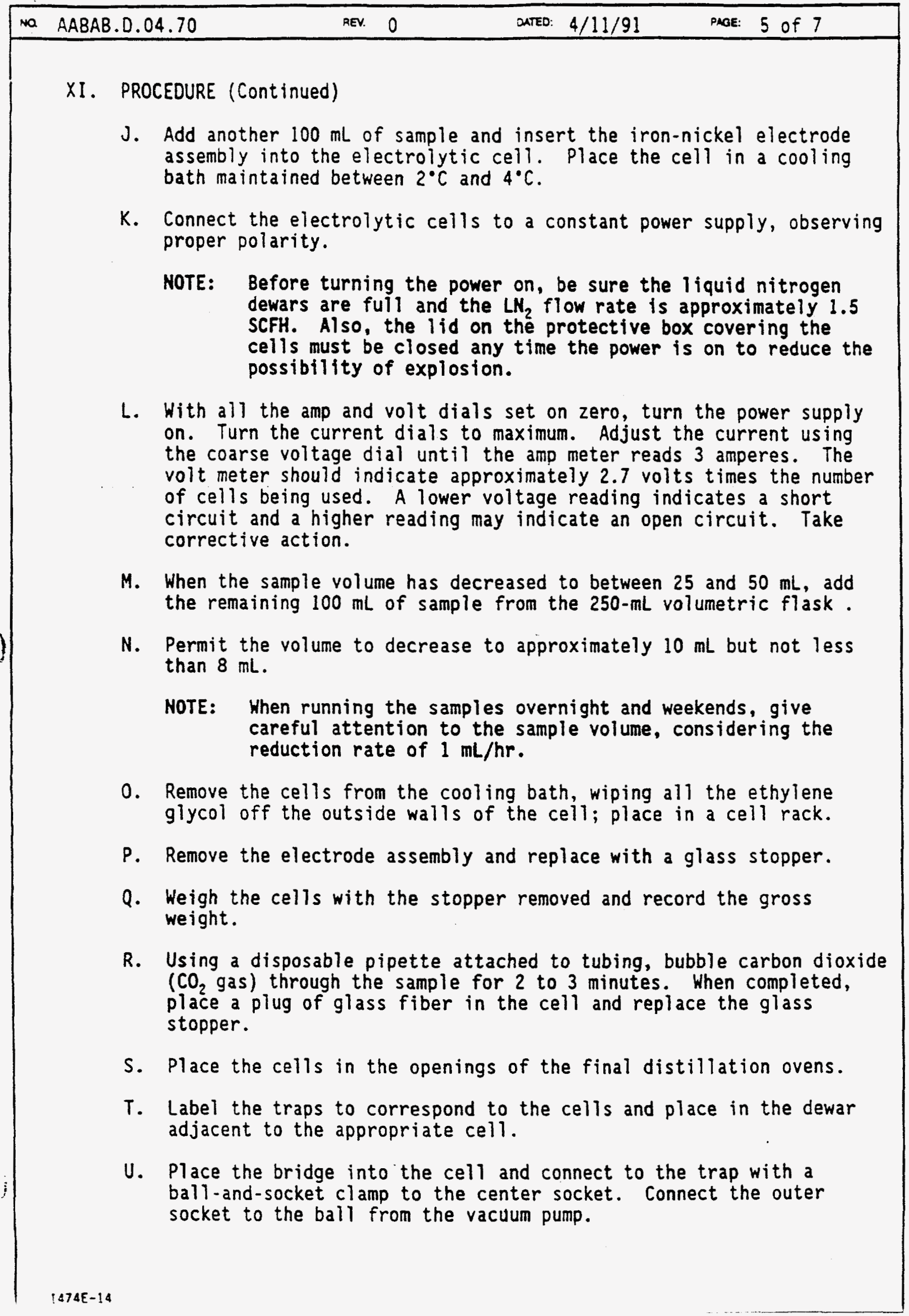


XI. PROCEDURE (Continued)

$V$. Turn on the vacuum pump, and check all the connections; then fill each trap dewar $1 / 3$ full with liquid nitrogen.

$W$. Turn on the heating ovens to $150^{\circ} \mathrm{C}$, applying heat to the electrolytic cells. Cover the outside cell wall with aiuminum foil from the top of the oven to the bridge. Continue heating until the entire sample has been distilled. The temperature may be increased to $200^{\circ} \mathrm{C}$ if necessary. When completed, turn off the heat and let the vacuum run for approximately 15 more minutes.

$x$. Remove the traps, place in a rack, cover the socket openings with para-film, and allow to defrost.

Y. Transfer the sample from the trap to a labeled scintillation vial. Pipet $5 \mathrm{~mL}$ of sample into a labeled scintillation vial containing 10 $\mathrm{mL}$ of Pico-fluor scintillation cocktail.

2. Place the scintillation vials containing the samples into a varisette cassette and allow to dark adapt one to two hours.

AA. Count each sample twice for 100 minutes or whatever time is deemed appropriate for the samples.

BB. Check the printer for paper and to begin counting, press the green start key on the keyboard.

XII. CALIBRATION

Prepare an enrichment curve by enriching a set of standard tritium samples using the same procedure as for the unknowns. Allow the final volume of enriched solution to vary so that different points are obtained for the construction of the curve.

XIII. QUALITY CONTROL

As the activity of many of the samples is below the minimum detectable concentration, samples with higher activities are recycled as blind duplicates.

A. Calculations

Tritium $(\mu \mathrm{C} \mathrm{i} / \mathrm{ml})=$

$\frac{A-B}{2.22 \times 10^{6} \times E f f \times D \times E \times V}$

where

$A=$ counts per minute of the sample

$B=$ counts per minute of the background sample

$2.22 \times 10^{6}=\mathrm{dpm} / \mu \mathrm{Ci}$

Eff = fractional counting efficiency

$0=$ sample dilution factor (volume of sample divided by

volume counted, if dilution to $5 \mathrm{~mL}$ is necessary) 


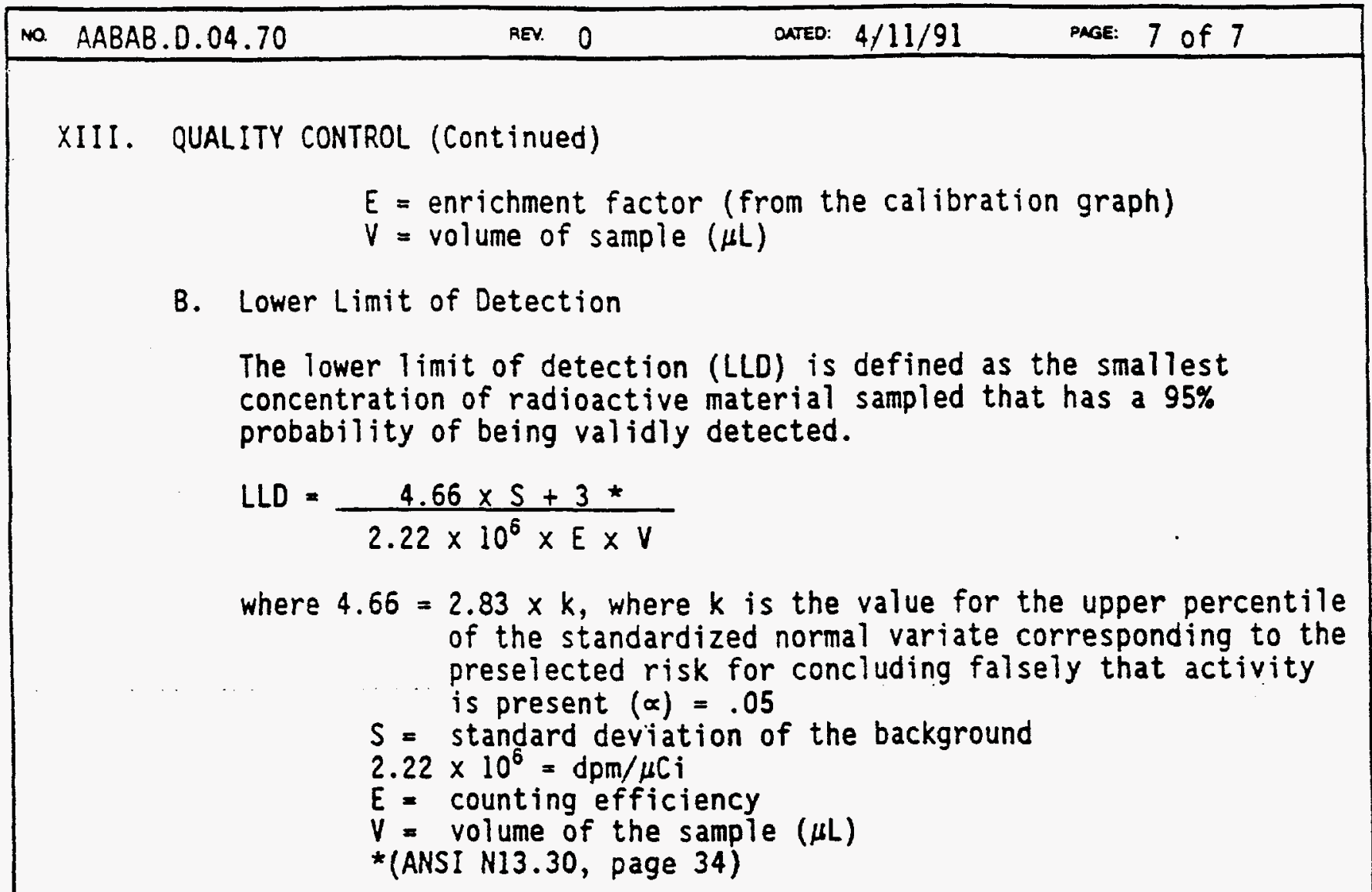




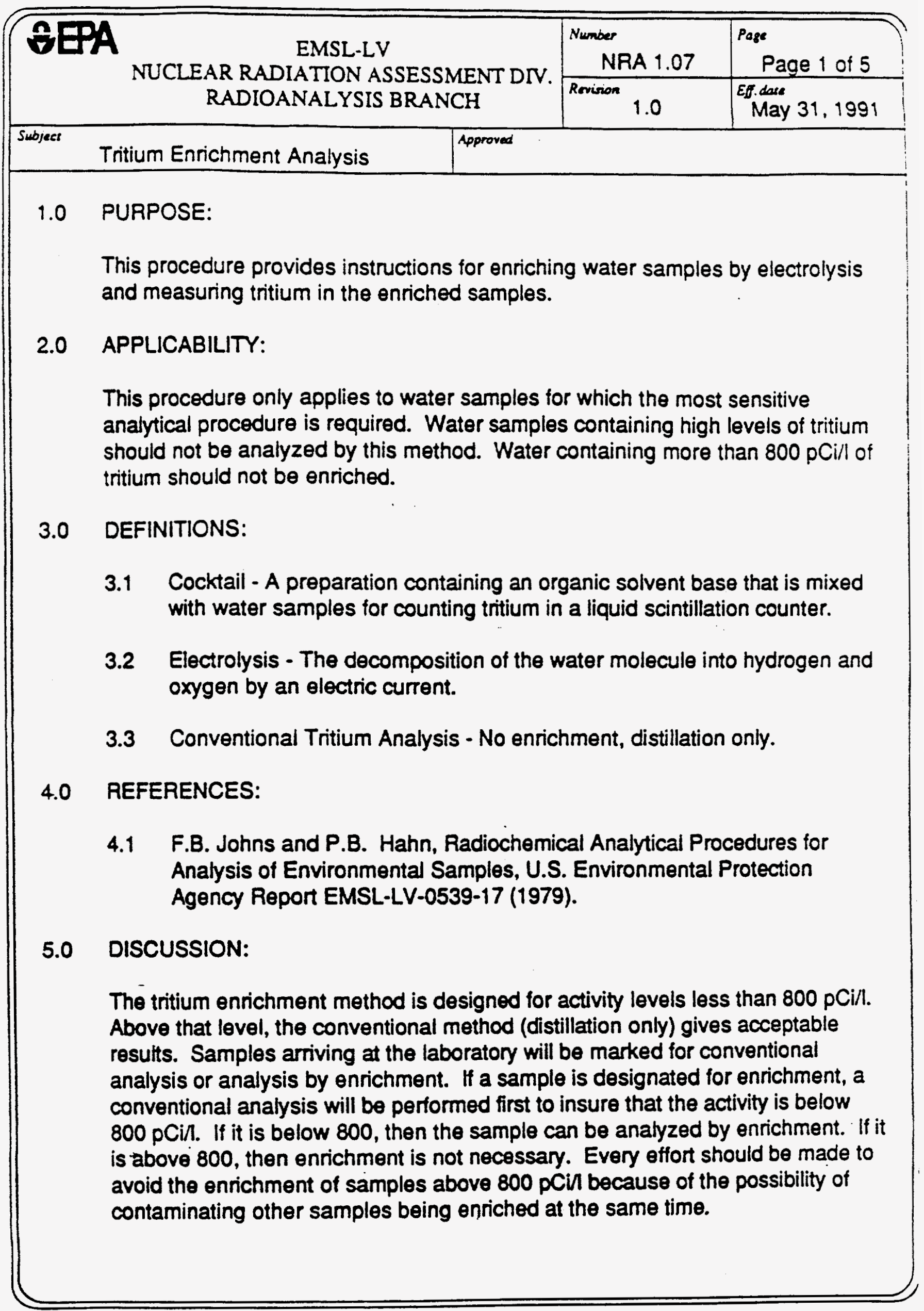




\begin{tabular}{|c|c|}
\hline $\begin{array}{c}\text { Number } \\
\text { NRA 1.07 }\end{array}$ & $\begin{array}{c}\text { Page } \\
\text { Page 3 of 5 }\end{array}$ \\
\hline Revision \\
1.0 & Eay 31, 1991 \\
\hline
\end{tabular}

8.7 The electrolysis procedure produces hydrogen gas which may explode if a spark or other source of ignition is present. Cover the cells with the protective cover when in use to contain any glass that may be released by the small explosions that have sometimes occurred. TO AVOID SPARKS, THE CURRENT MUST BE TURNED OFF BEFORE REMOVING THE PROTECTIVE COVER. Failure to do this could result in serious injury.

8.8 Add additional water to the cells when ever the original volume is decreased by 50 percent. Repeat these additions until a total of $250 \mathrm{ml}$ of water has been reduced to approximately $5 \mathrm{ml}$.

8.9 Remove the electrodes from the cells and bubble carbon dioxide through the remaining liquid for a few minutes. The sample is now ready for vacuum distillation.

8.10 Connect the elctrolysis cell to the glass cold trap with a ground joint adapter. Connect the assembly to a vacuum pump. Immerse trap in liquid nitrotgen and apply vacuum. When trap is cold, apply heat to electrolytic cell. Continue heating to dryness. Discontinue heat but continue vacuum for 10 to 15 minutes.

8.11 Disconnect the apparatus and allow the ice to thaw. Keep evaporation to a minimum and seal sample container if there is any delay in processing.

8.12 Transfer the water to a tared scintillation vial and weigh.

8.13 Obtain the weight of the water by subtracting the empty vial weight. If needed, add background water to the vial until it contains $5 \mathrm{ml}$. Record the volume of water added ( $1 \mathrm{ml}=1 \mathrm{gram})$.

8.14 Add $15 \mathrm{ml}$ of scintillation cocktail to each vial and prepare standards and backgrounds in the same proportion.

8.15 Place samples in counter for at least one day before counting. Count each sample three times for 100 minutes each time.

8.16 After the samples are counted, average the counts and use the chemistry programs on the DOENAX to calculate the results. Final results will be checked by the laboratory supervisor before the data is entered into the data base. (See NRA 1.10). 
Subject

Tritium Enrichment Analysis

\begin{tabular}{|c|c|}
\hline $\begin{array}{c}\text { Number } \\
\text { NRA 1.07 }\end{array}$ & $\begin{array}{l}\text { Page } \\
\text { Page 5 of } 5\end{array}$ \\
\hline Revision & Ef. dere \\
1.0 & May 31, 199. \\
\hline
\end{tabular}

12.0 MODIFICATIONS:

When field modifications to this procedure become necessary, the supervisor shall fully document the changes, submit the documentation for the same review and distribution processes as for the original procedure, and indicate whether the change should result in a subsequent revision to the technical procedure.

13.0 ATTACHMENTS:

N/A

14.0 APPROVAL:

This TSOP shall become effective upon completion of all required signatures and dates on this TSOP and the TSOP QA and Technical Review. 
ENRICHED TRITIUM RESULTS OF GROUNDWATER SAMPLES COLLECTED BY REECo AND EMSL-LV IN 1992 FROM

WATER-SUPPLY WELLS AT THE NEVADA TEST SITE 
Enriched tritium results of groundwater samples collected by REECo in 1992 from water-supply wells at the Nevada Test Site.

\begin{tabular}{|c|c|c|c|}
\hline Water Well & Sample Date & Concentration $(\mathrm{pCi} / \mathrm{L})$ & Standard Deviation $(\mathrm{pCi} / \mathrm{L})$ \\
\hline Army \#1 & $\begin{array}{l}02 / 24 / 93 \\
04 / 06 / 92 \\
07 / 13 / 92 \\
10 / 05 / 92\end{array}$ & $\begin{array}{r}3.9 \\
1.5 \\
-2.1 \\
-25\end{array}$ & $\begin{array}{l}4.4 \\
4.6 \\
4.2 \\
6.5\end{array}$ \\
\hline 4 & $\begin{array}{l}02 / 24 / 93 \\
04 / 06 / 92 \\
07 / 13 / 92 \\
10 / 05 / 92\end{array}$ & $\begin{array}{r}-1.2 \\
0.4 \\
-1.9 \\
-23\end{array}$ & $\begin{array}{l}4.3 \\
4.2 \\
4.2 \\
6.6\end{array}$ \\
\hline $5 B$ & $10 / 05 / 92$ & 3.9 & 6.6 \\
\hline $5 \mathrm{C}$ & $\begin{array}{l}02 / 24 / 93 \\
04 / 06 / 92 \\
07 / 13 / 92 \\
10 / 05 / 92\end{array}$ & $\begin{array}{l}-4.1 \\
-0.3 \\
-1.8 \\
-24\end{array}$ & $\begin{array}{l}4.2 \\
4.2 \\
4.1 \\
6.6\end{array}$ \\
\hline 8 & $\begin{array}{l}02 / 24 / 93 \\
04 / 06 / 92 \\
07 / 13 / 92 \\
10 / 05 / 92\end{array}$ & $\begin{array}{c}-3.3 \\
0.7 \\
-2.3 \\
-30\end{array}$ & $\begin{array}{l}4.5 \\
4.2 \\
4.0 \\
6.6\end{array}$ \\
\hline $\mathrm{U}-20$ & $\begin{array}{l}04 / 06 / 92 \\
07 / 13 / 92 \\
10 / 05 / 92\end{array}$ & $\begin{array}{r}0.5 \\
0.4 \\
-1.1\end{array}$ & $\begin{array}{l}4.4 \\
4.2 \\
7.0\end{array}$ \\
\hline $\mathrm{C}$ & $\begin{array}{l}02 / 24 / 93 \\
04 / 06 / 92 \\
07 / 13 / 92 \\
10 / 05 / 92\end{array}$ & $\begin{array}{l}5.3 \\
23 \\
15 \\
-9.1\end{array}$ & $\begin{array}{l}4.5 \\
4.5 \\
4.4 \\
6.8\end{array}$ \\
\hline$C-1$ & $\begin{array}{l}02 / 24 / 93 \\
04 / 06 / 92 \\
07 / 13 / 92 \\
10 / 05 / 92\end{array}$ & $\begin{array}{r}1.2 \\
4.3 \\
5.2 \\
-17\end{array}$ & $\begin{array}{l}4.5 \\
4.2 \\
4.2 \\
6.7\end{array}$ \\
\hline $\mathrm{J}-12$ & $\begin{array}{l}05 / 12 / 92 \\
07 / 13 / 92 \\
10 / 05 / 92\end{array}$ & $\begin{array}{l}-2.4 \\
-2.4 \\
-30\end{array}$ & $\begin{array}{l}3.9 \\
4.2 \\
6.6\end{array}$ \\
\hline $\mathrm{J}-13$ & $\begin{array}{l}02 / 24 / 93 \\
04 / 06 / 92 \\
07 / 13 / 92 \\
10 / 05 / 92\end{array}$ & $\begin{array}{l}0.2 \\
2.3 \\
-2.6 \\
-26\end{array}$ & $\begin{array}{l}4.3 \\
4.2 \\
4.2 \\
6.5\end{array}$ \\
\hline $\mathrm{UE}-5 \mathrm{C}$ & $02 / 24 / 92$ & -1.0 & 4.3 \\
\hline UE-19c & $02 / 24 / 92$ & 0.6 & 4.4 \\
\hline UE-16d & $\begin{array}{l}02 / 24 / 93 \\
04 / 06 / 92 \\
07 / 13 / 92 \\
10 / 05 / 92\end{array}$ & $\begin{array}{l}-3.5 \\
-0.7 \\
-2.1 \\
-26\end{array}$ & $\begin{array}{l}4.2 \\
4.2 \\
4.1 \\
6.5\end{array}$ \\
\hline
\end{tabular}


Enriched tritium results of groundwater samples collected by EMSL-LV in 1992 from water-supply wells at the Nevada Test Site.

\begin{tabular}{|c|c|c|c|}
\hline Water Well & Sample Date & Concentration (pCi/L) & Standard Deviation (pCi/L) \\
\hline Army \#1 & $\begin{array}{l}01 / 07 / 92 \\
02 / 03 / 92 \\
03 / 03 / 92 \\
04 / 02 / 92 \\
05 / 12 / 92 \\
06 / 03 / 92 \\
07 / 08 / 92 \\
08 / 04 / 92 \\
09 / 01 / 92 \\
10 / 05 / 92 \\
11 / 09 / 92 \\
12 / 01 / 92\end{array}$ & $\begin{array}{c}1.0 \\
-1.1 \\
1.0 \\
-1.5 \\
0 \\
-2.1 \\
0.9 \\
-0.5 \\
1.6 \\
3.2\end{array}$ & $\begin{array}{l}1.8 \\
1.8 \\
1.7 \\
2.2 \\
1.4 \\
1.7 \\
1.9 \\
1.7 \\
1.4 \\
1.7 \\
1.5 \\
1.5\end{array}$ \\
\hline 4 & $\begin{array}{l}01 / 07 / 92 \\
02 / 03 / 92 \\
03 / 03 / 92 \\
04 / 02 / 92 \\
05 / 12 / 92 \\
06 / 02 / 92 \\
07 / 07 / 92 \\
08 / 04 / 92 \\
09 / 02 / 92 \\
10 / 05 / 92 \\
11 / 09 / 92 \\
12 / 01 / 92\end{array}$ & $\begin{array}{c}-1.1 \\
1.2 \\
-0.8 \\
-2.1 \\
0 \\
-2.1 \\
2.9 \\
-2.2 \\
-0.5 \\
1.6 \\
-4.8 \\
0.5\end{array}$ & $\begin{array}{l}1.8 \\
2.0 \\
1.5 \\
1.9 \\
1.4 \\
1.7 \\
1.8 \\
1.4 \\
1.9 \\
1.6 \\
1.5 \\
1.5\end{array}$ \\
\hline $5 B$ & $08 / 04 / 92$ & 3.1 & 1.4 \\
\hline $5 \mathrm{C}$ & $\begin{array}{l}01 / 07 / 92 \\
02 / 03 / 92 \\
03 / 03 / 92 \\
04 / 02 / 92 \\
05 / 12 / 92 \\
06 / 02 / 92 \\
07 / 08 / 92 \\
08 / 04 / 92 \\
09 / 01 / 92 \\
10 / 05 / 92 \\
11 / 10 / 92 \\
12 / 01 / 92\end{array}$ & $\begin{array}{r}1.7 \\
3.7 \\
-1.6 \\
-1.3 \\
1.6 \\
-2.7 \\
1.4 \\
0.5 \\
1.8 \\
-0.5 \\
-2.5 \\
-0.6\end{array}$ & $\begin{array}{l}1.5 \\
2.1 \\
1.4 \\
1.2 \\
1.5 \\
1.4 \\
1.6 \\
1.3 \\
1.3 \\
1.6 \\
1.4 \\
2.0\end{array}$ \\
\hline
\end{tabular}


Enriched tritium results of groundwater samples collected by EMSL-LV in 1992 from water-supply wells at the Nevada Test Site (continued).

\begin{tabular}{|c|c|c|c|}
\hline Water Well & Sample Date & Concentration $(\mathrm{pCi} / \mathrm{L})$ & Standard Deviation $(\mathrm{pCi} / \mathrm{L})$ \\
\hline 8 & $\begin{array}{l}01 / 07 / 92 \\
02 / 03 / 92 \\
03 / 03 / 92 \\
04 / 01 / 92 \\
05 / 12 / 92 \\
06 / 02 / 92 \\
07 / 07 / 92 \\
08 / 04 / 92 \\
09 / 01 / 92 \\
10 / 05 / 92 \\
11 / 09 / 92 \\
12 / 01 / 92\end{array}$ & $\begin{array}{c}0 \\
0 \\
10 \\
-1.7 \\
-0.6 \\
-5.1 \\
0 \\
-1.3 \\
2.1 \\
1.9 \\
-1.5 \\
-0.4\end{array}$ & $\begin{array}{l}1.7 \\
2.0 \\
1.9 \\
1.5 \\
1.6 \\
1.5 \\
1.6 \\
1.5 \\
1.4 \\
1.5 \\
1.3 \\
1.5\end{array}$ \\
\hline $\mathrm{U}-20$ & $\begin{array}{l}04 / 02 / 92 \\
05 / 12 / 92 \\
06 / 02 / 92 \\
07 / 07 / 92 \\
08 / 04 / 92 \\
09 / 01 / 92 \\
10 / 05 / 92 \\
12 / 02 / 92\end{array}$ & $\begin{array}{r}-1.9 \\
-3.0 \\
-0.7 \\
4.0 \\
1.9 \\
1.6 \\
4.9 \\
1.0\end{array}$ & $\begin{array}{l}1.7 \\
1.7 \\
1.5 \\
1.7 \\
1.6 \\
1.6 \\
1.7 \\
1.4\end{array}$ \\
\hline $\mathrm{C}$ & $\begin{array}{l}01 / 07 / 92 \\
02 / 03 / 92 \\
04 / 01 / 92 \\
05 / 12 / 92 \\
06 / 02 / 92 \\
07 / 07 / 92 \\
08 / 04 / 92 \\
09 / 01 / 92 \\
10 / 05 / 92 \\
11 / 09 / 92 \\
12 / 01 / 92\end{array}$ & $\begin{array}{l}11 \\
24 \\
21 \\
12 \\
19 \\
15 \\
20 \\
12 \\
13 \\
18 \\
17\end{array}$ & $\begin{array}{l}1.8 \\
2.0 \\
2.3 \\
1.7 \\
1.8 \\
1.9 \\
1.8 \\
1.5 \\
1.9 \\
1.7 \\
2.1\end{array}$ \\
\hline C-1 & $\begin{array}{l}04 / 01 / 92 \\
10 / 05 / 92\end{array}$ & $\begin{array}{l}17 \\
4.7\end{array}$ & $\begin{array}{l}2.1 \\
1.6\end{array}$ \\
\hline $\mathrm{J}-12$ & $\begin{array}{l}05 / 12 / 92 \\
06 / 02 / 92 \\
07 / 08 / 92 \\
08 / 04 / 92 \\
09 / 01 / 92 \\
10 / 05 / 92 \\
11 / 10 / 92 \\
12 / 02 / 92\end{array}$ & $\begin{array}{c}1.0 \\
-3.2 \\
1.1 \\
-0.2 \\
2.2 \\
0 \\
-3.9 \\
1.3\end{array}$ & $\begin{array}{l}1.7 \\
1.8 \\
1.9 \\
1.6 \\
1.4 \\
1.4 \\
1.4 \\
1.5\end{array}$ \\
\hline
\end{tabular}


Enriched tritium results of groundwater samples collected by EMSL-LV in 1992 from water-supply wells at the Nevada Test Site (continued).

\begin{tabular}{lccc}
\hline \hline Water Well & Sample Date & Concentration $(\mathrm{pCi} / \mathrm{L})$ & Standard Deviation $(\mathrm{pCi} / \mathrm{L})$ \\
\hline $\mathrm{J}-13$ & $01 / 07 / 92$ & 0 & 1.6 \\
& $02 / 03 / 92$ & -2.0 & 1.7 \\
$03 / 03 / 92$ & -2.6 & 2.2 \\
$04 / 02 / 92$ & 0 & 1.5 \\
$05 / 12 / 92$ & 0 & 1.4 \\
& $06 / 12 / 92$ & -0.7 & 1.6 \\
& $07 / 08 / 92$ & 0.2 & 1.2 \\
& $08 / 04 / 92$ & 3.7 & 1.9 \\
& $09 / 01 / 92$ & 1.6 & 1.7 \\
& $10 / 05 / 92$ & 3.1 & 1.5 \\
& $11 / 09 / 92$ & -1.5 & 1.6 \\
& $12 / 01 / 92$ & 2.6 & 1.4 \\
UE-5C & $05 / 12 / 92$ & -2.9 & 1.6 \\
& $09 / 01 / 92$ & -1.1 & 1.5 \\
UE-19c & $01 / 07 / 92$ & -1.1 & 1.8 \\
& $02 / 03 / 92$ & -1.1 & 1.8 \\
& $03 / 02 / 92$ & 0 & 1.5 \\
& $04 / 02 / 92$ & -2.1 & 1.9 \\
& $05 / 12 / 92$ & -2.1 & 1.5 \\
& $06 / 02 / 92$ & 0.5 & 1.8 \\
& $07 / 07 / 92$ & 0.9 & 1.5 \\
& $08 / 04 / 92$ & 5.3 & 1.5 \\
& $09 / 01 / 92$ & -0.7 & 1.4 \\
& $10 / 05 / 92$ & 0.8 & 1.5 \\
& $12 / 02 / 92$ & 5.0 & 1.7 \\
& $05 / 12 / 92$ & -4.6 & 1.8 \\
& $11 / 09 / 92$ & 2.3 & 1.4 \\
\hline
\end{tabular}


APPENDIX E

U.S. ENVIRONMENTAL PROTECTION AGENCY LETTER RECOMMENDING ENRICHED TRITIUM INTERLABORATORY COMPARISON PROGRAM

E-1 


\section{UNTTED STATES ENVIRONMENTAL PROTECTION AGENCY \\ OFFICE OF RESEARCH AND DEVELOPMENT \\ ENVIRONMENTAL MONITORING SYSTEMS LABORATORY-LAS VEGAS \\ P.O. BOX 93478 \\ LAS VEGAS. NEVADA 89193-3478 \\ (702/798-2100 - FTS 545-2100) \\ MAY 141993}

Mr. Richard H. Pearl, Physical Scientist

Environmental Protection Division (M/S 505)

U.S. Department of Energy

P.O. Box 98518

Las Vegas, Nevada 89193-8518

SUBJECT: Summary of Enriched Tritium Subcommittee Meeting, May 13, 1993

Dear Mr. Pearl:

The Enriched Tritium Subcommittee met at the Environmental Protection Agency Environmental Monitoring Systems Laboratory-Las Vegas on May 13, 1993. Attendees are listed in Enclosure 1. Topics of discussion included design of an intercomparison study for enriched tritium, methodology, and quality assurance/quality control. A copy of the agenda is included as Enclosure 2.

The attendees unanimously and vigorously support the implementation of an intercomparison study. Participation in a long-term, ongoing intercomparison study is critical for all laboratories using the enriched tritium analysis method. The following summarizes the group's recommended specifications:

- The intercomparison study samples should be prepared by an independent laboratory, such as Environmental Measurements Laboratory.

- For the first year, one round per quarter should be conducted. After completion of the first year, the frequency should be evaluated and, possibly, modified.

- Each round should consist of three intercomparison study samples of the same activity and one matrix blank.

- $\quad$ Each intercomparison study sample should be approximately 1 liter. Samples need to be in glass containers, with a minimum of headspace (10\%), and sealed. Fossil water is required for the sample matrix.

- Intercomparison study samples should be in the range of 100 to $200 \mathrm{pCi} / \mathrm{L}$.

- Data analysis is the responsibility of the preparation laboratory. 
Enclosure 1

Name

Deb Chaloud

Robert Holloway

Gene Easterly

John Akridge

Virginia Eno

Ron Hershey

Pat McQueen

Robert Elkins

Steven Bakhtiar

Jo Ann Rego

Steven Kreek

Jim Merrigan
Affiliation

Phone

EPA EMSL-LV

$702-798-2333$

EPA EMSL-LV

EPA EMSL-LV

EPA EMSL-LV

DRI

DRI

DRI-Reno

REECo

REECO

LLNL

LLNL

LLNL
$702-798-2325$

$702-798-2108$

$702-798-2673$

702-895-0465

702-895-0472

$702-673-7380$

702-295-5901

702-295-7559

510-422-5516

510-423-2594

510-424-6983 
Meeting Date: Thursday, May 13, 1993, 8:00am-2:00pm

Place: Quality Assurance Division Conference Room

U.S. Environmental Protection Agency

944 E. Harmon Ave.

Las Vegas, Nevada

(see enclosed map)

I. Introductory Remarks (8:00am - 8:15am)

Introductions

Purpose of Committee

II. Intercomparison Study (All) (8:15am - 9:45am)

Spiked or natural samples?

Desired activity range?

Frequency/total no. of samples?

Single or double-blind?

Logistic issues (shipping, storage, etc.)

Source/supplier?

Data submission/compilation?

Results/reports?

Costs?

Other issues?

Break (9:45am - 10:00am).

IIIa. Analytical Methods (Chemists) (10:00am - 11:30am)

Is a standard method available?

If so, who is using, who is not, why?

Is a standard method appropriate?

Why/why not?

If yes, who to develop, who to test, where to document (publish)?

Should methodology be performance-based?

If so, specify criteria

If not, how can comparability of analytical methods be assured/measured? Costs?

Other issues? 
Ms. Jo Ann Rego

Chemist (M/S L-231)

Lawrence Livermore National Laboratory

P.O. Box 808L

Livermore, California 94550

$510-422-5516$

Dr. Paul Seaber

Research Professor (M/S 505)

Desert Research Institute

P.O. Box 19040

Las Vegas, NV 89132

702-895-0487

\section{Dr. Steven Bakhtiar}

Radioanalytical Chemist (M/S 772)

Reynolds Engineering \& Electric Company, Inc.

P.O. Box 98521

Las Vegas, NV 89193-8521

$702-295-7559$

Mr. Kevin Krenzien

Industrial Hygienist 3 (M/S 713)

Reynolds Engineering \& Electric Company, Inc.

P.O. Box 98521

Las Vegas, NV 89193-8521

702-295-6576

Mr. Richard H. Pearl

Physical Scientist (M/S 505)

Environmental Protection Division

U.S. Department of Energy

P.O. Box 98518

Las Vegas, NV 89193-8518

702.295 .0853

Mr. Howard Hall

Chemist (M/S L-231)

Lawrence Livermore National Laboratory

P.O. Box 808L

Livermore, California 94550

510-422-7446

Mr. Jim Merrigan

Quality Assurance Officer (M/S L-231)

Lawrence Livermore National Laboratory

P.O. Box 808L

Livermore, California 94550

510.424-6983

Ms. Virginia Eno

Staff Quality Assurance (M/S 505)

Desert Research Institute

P.O. Box 19040

Las Vegas, NV 89132

702-895-0465
Mr. Ron Hershey

Staff Hydrologist (M/S 505)

Desert Research Institute

P.O. Box 19040

Las Vegas, NV 89132

702-895-0472

Mrs. Patricia McQueen

Chemist

Desert Research Institute

P.O. Box 60220

Reno, NV 89506

$702-673-7380$

Mr. Steven Kreek

Postdoctoral Research Fellow (M/S L-237)

Nuclear Chemistry Division

Lawrence Livermore National Laboratory

Livermore, CA 94550

510-423-2590

Ms. Deb J. Chaloud

Physical Scientist (M/S 513)

U.S. Environmental Protection Agency

Environmental Monitoring Systems Laboratory-Las

Vegas

P.O. Box 93478

Las Vegas, NV 89193-3478

702-798-2333

Dr. Robert W. Holloway

Chemist

U.S. Environmental Protection Agency

Environmental Monitoring Systems Laboratory-Las

Vegas

P.O. Box 93478

Las Vegas, NV 89193-3478

702-798-2325

Mr. David Gene Easterly

QA Program Manager

U.S. Environmental Protection Agency

Environmental Monitoring Systems Laboratory-Las

Vegas

P.O. Box 93478

Las Vegas, NV 89193-3478

702-798-2108

Dr. John D. Akridge

Chemist

U.S. Environmental Protection Agency

Environmental Monitoring Systems Laboratory-Las

Vegas

P.O. Box 93478

Las Vegas, NV 89193-3478

$702-798-2673$ 
Mr. Robert Elkins

Chemist (M/S 713)

Reynolds Engineering \& Electric Company, Inc.

P.O. Box 98521

Las Vegas, NV 89193-8521

702-295-5901 
APPENDIX F

LIST OF POTENTIAL GROUNDWATER MONITORING WELLS

F-1 


\section{AREA :}

Well Name

\section{Army 6A}

Paleozoic Carbonates

SWL : 1030

WLM : N/A

N665641

Elevation ID completed

Cas

E 690214

$3445 \quad 1253$

1956

12.000

10.000

Erom Ie

Hole

Erom

Ie

Interval

From

Io

Sampled by : EPA

PM-3 \#1

Tertiary Volcanics

N906022

$5823 \quad 3019$

1992

10.750

o 1473

18.000

16.000

$0 \quad 50$

10.000 12001253

Perts 10501150

Peits $1157 \quad 1228$

SWL : 1460

WLM : USGS

2.875

02142

$9.875 \quad 1647 \quad 3019$

Slots

$1917 \quad 2142$

Sampled by : N/A

PM-3 \#2

Tertiary Volcanics

\section{N906022}

$5823 \quad 3019$

1992

10.750

o 1473

E 530998

2.875

$\begin{array}{ll}0 & 1667\end{array}$

$9.875 \quad 1647 \quad 3019$

Slots

14421667

WLM : USGS

Sampled by : N/A 


\section{AREA :1}

Well Name

\section{UE-1Q}

Paleozoic Carbonates

SWL : 1655

WLM : USGS

N841500

Elovation ID

Completed

$4082 \quad 2600$

1992

Case

Erom

Io

E 677500

02459

12.250

Erom To

Interval

Erom

To

Sampled by : N/A

UE-1c

Tertiary/Paleozoic Carbonates

N837000

$4206 \quad 1880$

1964

10.750

$74 \quad 26.000$
9.000

$\begin{array}{rr}0 & 80 \\ 80 & 1280\end{array}$

Open

$74 \quad 1880$

SWL : 1298

WLM : USGS

Sampled by : EPA

Tertiary/Pz Carb at $1875^{\prime}$.

UE1A

N837000

$4303 \quad 957$

1964

10.750

E 660000

WLM : USGS

Sampled by : N/A

SWL. : 545

WLM : USGS

UE1B

N837000

$4273 \quad 1254$

1964

10.750

$\begin{array}{lll}0 & 76 & 9.000\end{array}$

$\begin{array}{ll}0 & 1254\end{array}$

Open

$76 \quad 1254$

Eleana (Upper Clastic Aquitard)

E 662000

SWL : 645

WLM : USGS

Sampled by : N/A

UE1H

N819998

$3995 \quad 3358$

1968

9.500

02134

12.250

1112349

$\begin{array}{lll}8.750 & 2349 & 3358\end{array}$

Open $2135 \quad 3358$

SWL : 1556

WLM : USGS

E 674999

Sampled by : N/A

UE1L

N837000
$E 654001$

4454

5339

1972

13.375

0716

17.500
12.250

\begin{tabular}{rr}
$76 \quad 726$ \\
\hline 720
\end{tabular}

Open

$716 \quad 5339$ 


\section{AREA .2}

Well Name

UE-2ce Water Well

Paleozoic Carbonates

SWL : 1446

WLM : USGS

E 654900

ID

completed

Case

$4764 \quad 1650$

1977

13.375

8.625

Erom To

Hele From Io

Interval Erom

Io

\section{WATER WELL 2 (USGS HTH \#2) N880000}

$4470 \quad 3422$

1962

8.500

$\begin{array}{lll}0 & 81 & 12.250\end{array}$

01650

Paleozoic Carbonates

E 668720

SWL : 2055 WLM : USGS Sampled by : EPA

Non-drinking water supply well. Pump set in hole. Does not work.Monitor line present in well. 


\section{AREA :3}

Well Name

TW-7

Tertiary

SWL : 1633

Elevation ID completed

N843192

E 684654

WLM : USGS Sampled by : EPA

\section{U-3en 5}

Tuft/Lower Carbonate/Lower

Clastic

SWL : 1625 WLM : USGS Sampled by : EPA

Tertiary/Pz Carbonates at 2821', Pz/Clastic at 2924'.

UE-3E \#4-1

$$
\text { N844888 }
$$

$4082 \quad 2300$

E 680001

SWL : 1084 WLM : USGS Sampled by : N/A

Plugged to 2182 ' with cement. Completed with 3 piezometer tubes.

\section{UE-3E \#4-2}

N844888
E 680001

$4082 \quad 2300$

1990

20.000
13.375

2.875

$\begin{array}{lr}0 & 117 \\ 0 & 1436\end{array}$

o 1919 $2321 \quad 2832$
5.750

28353028

SWL: 1309 WLM :USGS Sampled by : N/A

Plugged to 2182 ' with cement. Completed with 3 piezometer tubes.

\section{UE-3E \#4-3}

N844888
E 680001

SWL : 1551

1551 WLM : USGS Sampled by : N/A

E 680001

Plugged to $2182^{\prime}$ with cement. Completed with 3 piezometer tubes.

\section{USGS Water Well A}

USGS Wat
Alluvium

N833000
$4082 \quad 2300$

1990

20.000

13.375

2.875
0 117

01436

o 1661
36.000

17.500

12.250 o 120

$120 \quad 1442$

14422300
SWL : 1605

WLM : N/A

$4006 \quad 1870$

1960

12.625

10.625

o 1555

16.000

15.000

$\begin{array}{rr}0 & 601 \\ 601 & 1600 \\ 600 & 1870\end{array}$

Slots $\quad 1608 \quad 1870$ 


\section{AREA :4}

Well Name

TEST WELL D

Dolomite/Tertiary Volcanics

SWL: 1723 WLM :USGS Sampled by : EPA

U4U PS\#2A

N851215

41172280

1990

10.750

$0 \quad 120$

9.875

0 2280

Open

$1770 \quad 2280$

SWL : 1681

WLM : USGS

E 680078

2.875

o 1770

Sampled by : N/A

UE-4t 1

Tertiary Volcanics

SWL : 289

WLM : USGS

N855565

E 680350

$4144 \quad 2413$

1990

88.000

13.375

2.875

$\begin{array}{rrr}0 & 8 & 104.000 \\ 0 & 119 & 26.000 \\ 0 & 1993 & 9.875\end{array}$

$0 \quad 8$

121

o 2413

Sampled by : N/A

\section{N855565}

$4144 \quad 2413$

E 680350

Tertiary Volcanics

SWL : 1144

WLM : USGS
Sampled by : N/A 


\section{AREA :5}

Well Name

TW-3 (HTH -3)

Paleozoic Carbonates

N750189

Elevation

SWL: 1105 WLM : USGS Sampled by : NA

Cement Shoe at 1516

\section{UE-5C}

Alluvium

N760133

$3216 \quad 2682$

E 700997

1964

13.375

o 1682

12.250
9.875

$1682 \quad 2385$

23852682

SWL:

WLM : N/A Sampled by : REECO/EPA

UE-5n

Alluvium

N754460

$3112 \quad 1687$

1976

10.750

$\begin{array}{lll}0 & 1523 & 15.000\end{array}$

$\begin{array}{ll}0 & 1687\end{array}$

Perts

$720 \quad 730$

SWL : 705

WLM : USGS Sampled by : N/A

\section{WATER' WELL $5 A$}

Alluvium

N738361

$3093 \quad 910$

1951

12.000

$\begin{array}{lll}10.000 & 0 & 877\end{array}$

$0 \quad 910$

Slots

$642 \quad 877$

E 707263

SWL : 711

WLM : USGS

Sampled by : N/A

\section{WATER WELL 5B}

Alluvium

N747359

3092900

E 704263

WLM : N/A

Sampled by : REECO/EPA

Water Woll 5c

Alluvium

SWL : 692

WLM : N/A

N741644

$3081 \quad 1200$

E 706305

$\begin{array}{lll}10.750 & 0 & 1187\end{array}$

01200

Perfs

$887 \quad 1187$ 


\section{AREA :6}

Well Name

ER-6-1

Paleozoic Carbonates

N814000

Elevation

$3940 \quad 2129$

SWL: 1546

WLM : N/A

E 696799

Sampled by : N/A

\begin{tabular}{|c|c|}
\hline ER-6-1 Piezometer Tube & N814000 \\
\hline Tertiary & E 696799 \\
\hline WLM : N/A & Sampled by : N/A \\
\hline
\end{tabular}

Tube tack welded to side of 13.375" casing in ER-6-1

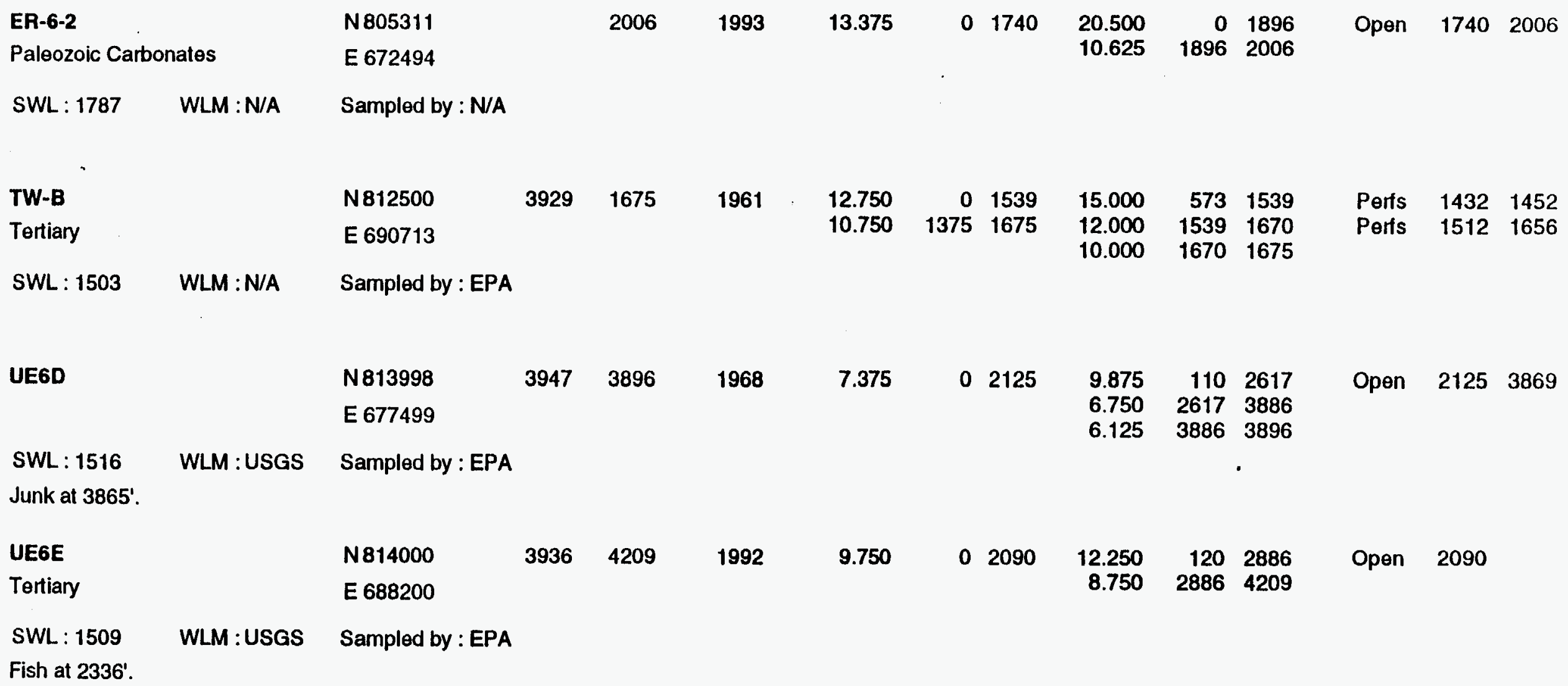




\section{AREA :6}

Well Name

USGS Water Well C

Paleozoic Carbonates

N790803

E 692061

\section{Elevalion ID \\ 1967}

SWL: 1541 WLM : N/A Sampled by : REECO/EPA

Pump hung at 1594' on 5.5" casing, 1/31/90, WL monitor not present. Drinking water supply well.

\section{WATER WELL 4}

Volcanic Tufis

\section{N784999}

3603

1479

1981

E 687900

SWL : 836

WLM : USGS

Sampled by : REECO/EPA

Drinking water supply well.

\section{WATER WELL 4A}

Volcanic Tuffs

N784348

E 686898

$3606 \quad 1516$

1990

24.000

13.375

$\begin{array}{lr}0 & 535 \\ 0 & 1501\end{array}$

48.000

30.000

20.500

$\begin{array}{rr}0 & 31 \\ 31 & 536 \\ 536 & 1516\end{array}$

SWL : 835

WLM : USGS

Sampled by : N/A

\section{WATER WELL C-1}

Paleozoic Carbonates

SWL : 1547

WLM : N/A
$3921 \quad 1707$

\section{E 692132}

Sampled by : REECO/EPA
Pump hung at $1631^{\prime}$ on $5.5^{\prime \prime}$ casing, 1989, WL monitor not present, Drinking water supply well.

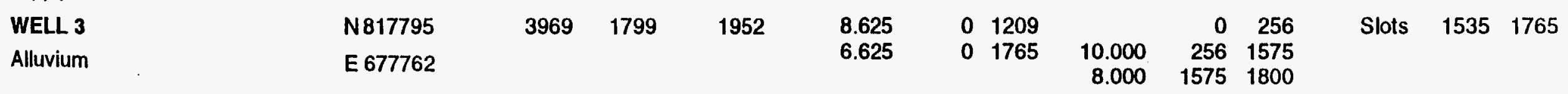

$\begin{array}{rrr}22.625 & 914 & 1539 \\ 19.000 & 1539 & 1596\end{array}$

$\begin{array}{lll}18.625 & 1596 & 1707\end{array}$

24.000

9101650
Perfs $\quad 1536 \quad 1650$

Slots $1066 \quad 1457$
150

\section{SWL : 1533 WLM :USGS Sampled by : N/A}




\section{AREA :7}

Well Name

Elevation ID Completed

N849002

E 681431

Tertiary

SWL : 1419

WLM : USGS

UE7N S

Paleozoic Carbonates

SWL : 1970

WLM : USGS
$4367 \quad 2199 \quad 1976$

E 693700

Sampled by : EPA 


\section{AREA :8}

Well Name

UEBF

SWL:

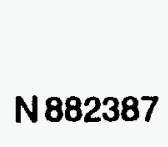

E 666019

\begin{tabular}{|c|c|c|c|c|c|c|c|c|c|c|}
\hline Elevation & ID & Completed & Case & Erom & Te & Hols & Erom & To & Interyal & Erom \\
\hline 4560 & 2248 & 1971 & 9.625 & 0 & 1129 & $\begin{array}{l}8.750 \\
6.250\end{array}$ & $\begin{array}{l}0 \\
0\end{array}$ & $\begin{array}{l}2235 \\
2248\end{array}$ & Open & 1129 \\
\hline
\end{tabular}

WLM : N/A Samplod by : N/A 


\section{AREA :9}

Well Name

U-9 ITS UE-U-29 \#1

Tertiary

Elevation ID completed

Cas

$4248 \quad 1248$

1971

13.375

Erom

To

Holo Erom

To

Interval

Erom

To

SWL :

WLM : N/A

E 683624

Sampled by : N/A

U-9 ITS UE-U-29 *2

N871505

$4242 \quad 1572$

1971

10.750

$0 \quad 79$

9.875

$\begin{array}{ll}0 & 1572\end{array}$

Open

$79 \quad 1572$

Tertiary

E 683105

SWL :

WLM : N/A

Sampled by : N/A 


\section{AREA :10}

Well Name

Elovation ID Completed

\section{UE-10 ITS \#3}

N887201

4353

2160

1969

Case

Erom

E 680700

Carbonates

WLM : N/A

Sampled by : N/A

Alluvium/Tertiary contact at $840^{\prime}$, Tertiary/Paleozoic contact at 2050', Plugged with cement to $1926^{\prime}$.

UE-10J

N 887033

$4574 \quad 2514 \quad 1993$

Paleozoic Carbonales

E 670453

20.000

13.375

$0 \quad 55$

$\begin{array}{ll}0 & 2198\end{array}$

9.635

612380

$2198 \quad 2515$

Open $\quad 2198 \quad 2514$

WLM : N/A

Sampled by : N/A 


\section{AREA :11}

Well Name

Elevation ID completed

Case Erom

From Ie

N777128

$3547 \quad 1400$

1982

20.000

E 708279

10.750

$\begin{array}{lllll}0 & 29 & 15.000 & 0 & 610\end{array}$

$\begin{array}{lllll}0 & 599 & 9.875 & 610 & 1400\end{array}$

Interval Erom To

Tertiary

SWL:1128 WLM:USGS Sampled by:N/A 


\section{AREA :12}

\section{Well Name}

\section{ER-12-1}

Lower Carbonate/Lower Clastic

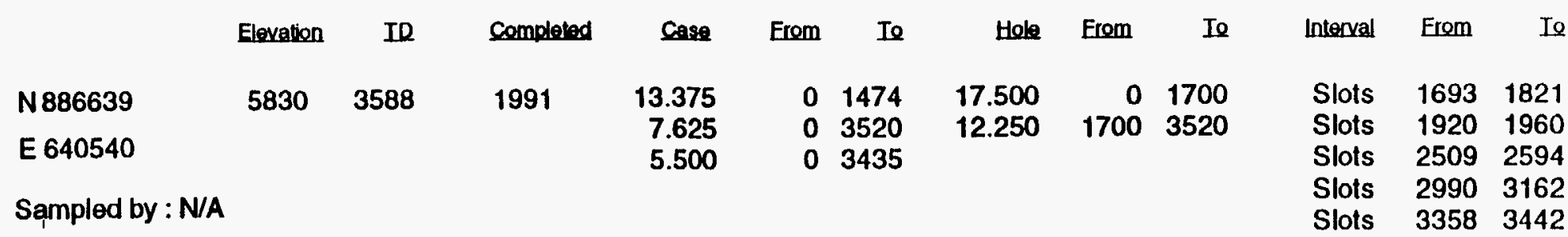

5-1/2" pipe with sliding side door sleves and external packers have been run to 3434 teet. Sleeves are all closed except top one at 1760 feet. DRI completed pump and sample test on 01/06/93. Pump to be removed soon

\section{U-12t6}

SWL : 784

$$
\text { N901402 }
$$

E 638431

\section{8}

Sampled by : N/A
7.000

4.500 $\begin{array}{rr}0 & 23 \\ 75 & 674\end{array}$

6.250

4.000

$23 \quad 674$

6741460

$\begin{array}{ll}\text { Cut } & 416 \\ \text { Cut } & 466 \\ \text { Cut } & 490 \\ \text { Cut } & 540 \\ \text { Cut } & 570 \\ \text { Cut } & 620\end{array}$




\section{AREA :14}

\section{Well Name}

UE14B

\begin{tabular}{|c|c|c|c|c|c|c|c|c|c|c|c|}
\hline & Elevation & ID & completed & Case & Erom & To & Hele & Erom & I0 & Interval & Erom \\
\hline N794100 & 4353 & 2060 & 1984 & 20.000 & 0 & 79 & $\begin{array}{l}13.500 \\
12.250\end{array}$ & $\begin{array}{l}0 \\
0\end{array}$ & $\begin{array}{l}2290 \\
3300\end{array}$ & Open & 79 \\
\hline
\end{tabular}

SWL : 1666

WLM : N/A

Sampled by : N/A 


\section{AREA :15}

Well Name

Elevation ID compleled

Case From Io

Hole Erom

Io Interval Erom

To

\section{UE-15d}

N895709

$4586 \quad 6001$

1962

7.000

$0 \quad 1735$

E 682084

$\begin{array}{lll}4.500 & 1667 \quad 5400\end{array}$

9.500

$\begin{array}{llll}765 & 1833 \text { Hole in } \mathrm{C}_{\varepsilon} \quad 734 \quad 751\end{array}$

Volcanic Tutís

Sampled by : EPA 


\section{AREA :16}

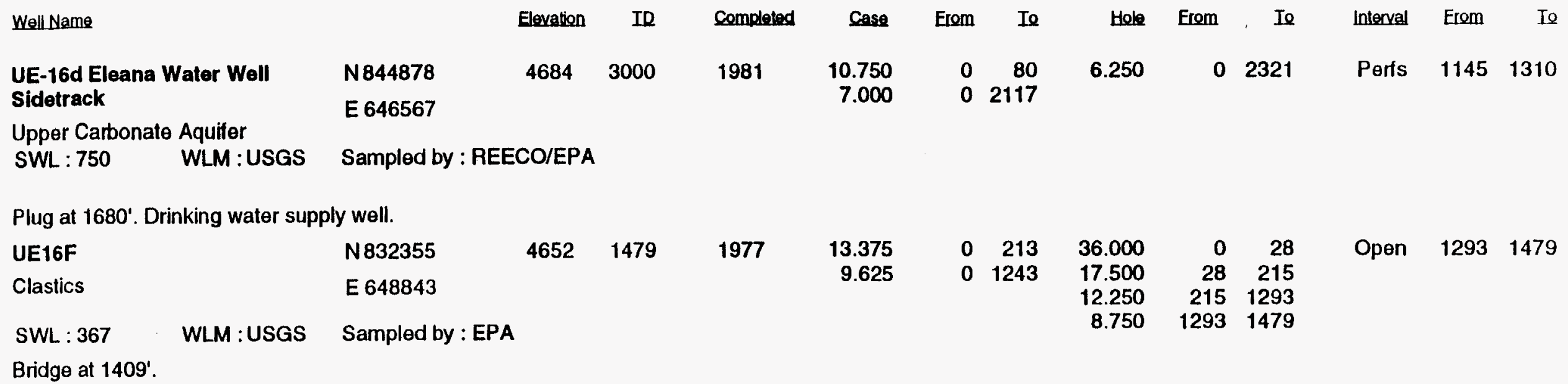




\section{AREA :17}

Well Name

UE17A

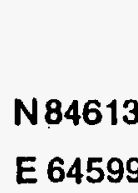

N846138

\section{Elevation}

4697

SWL : 636

WLM : USGS

Junk at 1207

\section{USGS HTH \#1}

Bedded Tuff/Lower Carbonate

\section{N876855}

E 629310

$6156 \quad 4206$

1962

WLM : USGS Sampled by : EPA

SWL : 1465

Tertiary/Carbonate contact at 3702', Bridge at 3700'.

$\begin{array}{rrrrrrrrrr} & \text { Case } & \text { From } & \text { To } & \text { Hole } & \text { Erom } & \text { To } & \text { Interval } & \text { Erom } & \text { To } \\ 976 & 7.625 & 0 & 36 & 26.000 & 4 & 38 & \text { Perfs } & 745 & 825 \\ & 4.500 & 0 & 1210 & 6.250 & 38 & 1214 & \text { Porfs } & 1005 & 1015 \\ & & & & & & & \text { Perfs } & 1065 & 1190\end{array}$

$\begin{array}{llllll}1.750 & 0 & 1615 & 7.625 & 0 & 4206\end{array}$

Perts 19101950

Perts 20302050

Perts 21002160

Perts 22302270

Perfs $2370 \quad 2430$ 
AREA :18

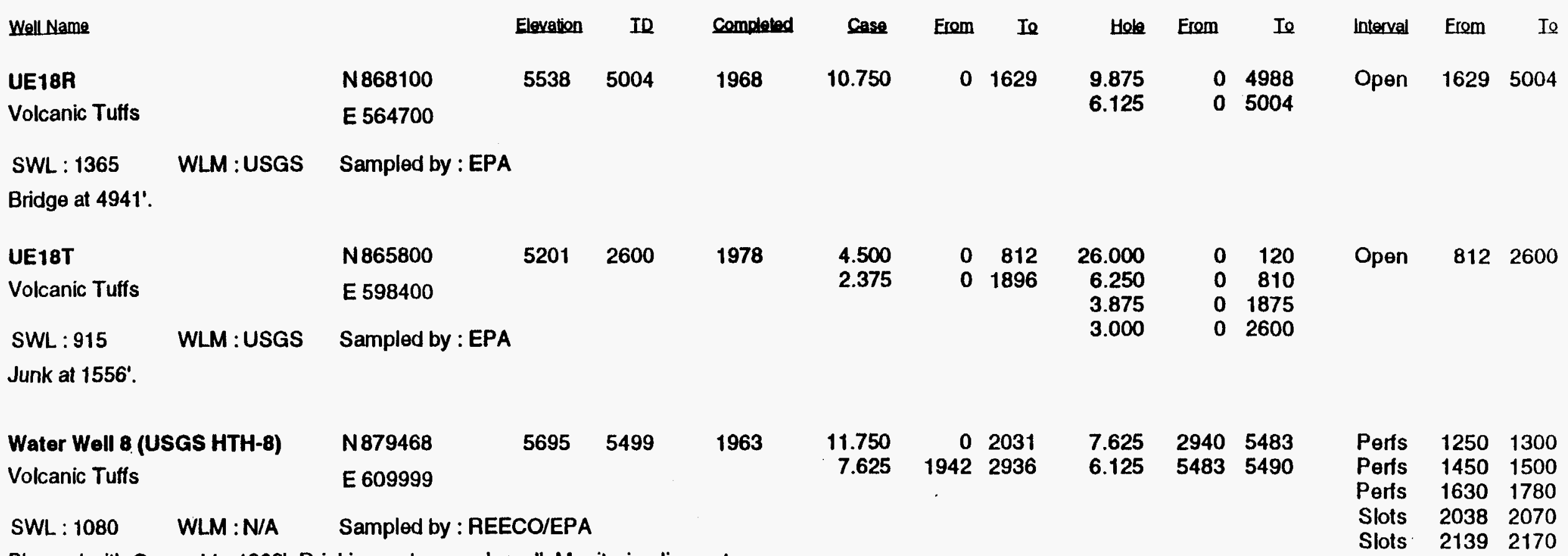

Plugged with Cement to 1862 '. Drinking water supply well. Monitoring line not present in well. 
AREA :19

Well Name

Elevation

Case

Erom

(n)

Enterval Erom

ER-19-1 N884237

3572

$1993 \quad 36.000$

$\begin{array}{lll}0 & 82 & 20.000\end{array}$

$82 \quad 3572$

Open

$82 \quad 3572$

Tertiany/Paleozoic Carbonates

E 624535

SWL : 1009

WLM : N/A

Sampled by : N/A

Tertiary/Pz contact at approximately $2840^{\prime}$.

\section{UE-19c Water Well}

N917000

E 601027

Volcanic Tutfs
$7033 \quad 8489$

WLM : USGS

Sampled by : REECO/EPA

Bridge at $3035^{\prime}$. Non-drinking water supply well.

$\begin{array}{ll}\text { UE-19h } & \text { N943901 } \\ \text { Tertiany } & \text { E } 585204\end{array}$

SWL:2109 WLM : USGS Sampled by : N/A

Plugged with cement to 2288'.

$6780 \quad 3705$

1992
13.375
2.875

$0 \quad 2321$

$\begin{array}{ll}0 & 2287\end{array}$
02422
12.250
24223209 32098489

Open $2422 \quad 3035$

. 


\section{AREA :20}

Well Name

ER-20-1

N899650

Tertiary

$$
\text { Elovation }
$$

ID

completed

Case

Erom To

Hele Erom To

Interval

Erom Io

SWL : 1986

WLM : N/A

E 550996

2056

1992

24.000

$\begin{array}{lll}0 & 1937 \quad 30.000\end{array}$

o 1940

Open 19372056

Sampled by : NA

PM-1

N921104

$6558 \quad 7858$

1962

10.750

$07534 \quad 9.625$

o 7858

Open 75347858

Volcanic Tuffs

E 575868

SWL : 2085

WLM : USGS Sampled by : EPA

\section{PM-2}

Tertiary

\section{N944581}

5586

8782

1964

13.375

O 2472

\section{E 528656}

9.625

O 5499

8.625

6.125

0 8775

0 8782

Open $\quad 5499 \quad 8782$

SWL : 852

WLM : N/A

Sampled by : N/A

U-20 Water Well

\section{N910582}

$6468 \quad 3268$

1982

13.375

o 3199

17.500

26843268

Slots

$3055 \quad 2271$

Volcanic Tuffs

E 569090

SWL : 2035

WLM : N/A

Sampled by : REECO/EPA

Non-drinking water supply well.

\section{U-20n PS \#1DD-H}

\section{N906531}

$6468 \quad 4250$

1985
$17.500 \quad 0 \quad 2430$
$9.875 \quad 3110 \quad 4520$

SWL : 2097 WLM :USGS Sampled by : N/A

Bridge Plug set at $3025^{\prime}, 5-15-85$.

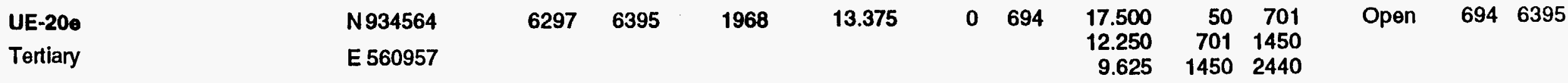




\section{AREA :20}

Well Name

UE20N1

Tertiary

Elevation ID completed

Case

Erom To

Erom

Io

Interval From

Io

SWL : 2040

N 906545

$6461 \quad 3300$

1987

13.375

$\begin{array}{rr}0 & 192 \\ 0 & 2282\end{array}$

17.500

\section{E 571239}

$\begin{array}{ll}0 & 197\end{array}$

Open $2282 \quad 3300$

WLM : USGS Sampled by : N/A

Bridge Plug at 2842', 6/10/87. 


\section{AREA :22}

Well Name

Army *1 Water Well

Paleozoic Carbonates

SWL : 800

WLM : N/A

Drinking water supply well.

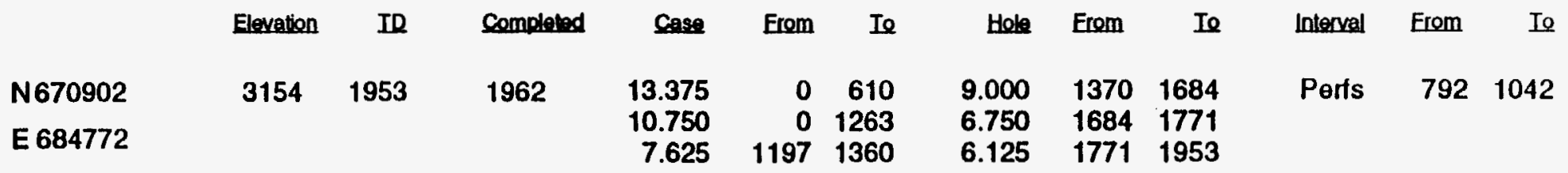

Sampled by : REECO/EPA 


\section{AREA :25}

Well Name

J-12 Water Well

Elevation

TD

Complated

Case Erom To

Hole Erom

Io

Interval

Erom

Io

Volcanic Tuffs

N733508

$3130 \quad 887$

1957

12.750

$\begin{array}{lll}0 & 887 & 11.750\end{array}$

$0 \quad 1139$

Perfs

793

868

SWL : 745

WLM : N/A

E 581012

Drinking water supply well.

\section{Water Well J-13 USGS HTH \#6}

N749209

3318

3488

1963

13.375

11.750

$\begin{array}{ll}0 & 1301\end{array}$

13011546

26.000

17.250

E 579651

$\begin{array}{llll}5.500 & 1484 & 3385 & 17.000\end{array}$

15.000

9.875

9.000

7.625

Perts $\quad 996 \quad 1301$

Perls $1301 \quad 1386$

Peris $2690 \quad 3312$

Drinking water supply well. 


\title{
AREA :27
}

Well Name

HTH F (TW-F)

Paleozoic Carbonates

SWL : 1734

Dead Pump in hole.

$\begin{array}{rrrrrrrrrrrr}\text { Elevation } & \text { ID } & \text { Complatad } & \text { Case } & \text { Erom } & \text { Io } & \text { Hole } & \text { Erom } & \text { To } & \text { Interval } & \text { Erom } & \text { Io } \\ 4143 & 3400 & 1962 & 8.625 & 0 & 3150 & 7.500 & 0 & 3400 & \text { Open } & 3150 & 3400\end{array}$

N731853

E 661153

WLM : USGS Sampled by : EPA

\author{
W
}




\section{DISTRIBUTION}

\author{
U.S. Department of Energy \\ Gylan Allen \\ Test Operations Division \\ Nevada Operations Office \\ U.S. Dept. of Energy \\ P.O. Box 98518 \\ Las Vegas, NV 89193-8518 \\ Doug Duncan \\ Hydrology Program Manager \\ Office of Environmental Restoration \& Waste \\ Management \\ Nevada Operations Office \\ U.S. Dept. of Energy \\ P.O. Box 98518 \\ Las Vegas, NV 89193-8518 \\ Don Elle, Director \\ Environment Protection Division \\ Nevada Operations Office \\ U.S. Dept. of Energy \\ P.O. Box 98518 \\ Las Vegas, NV 89193-8518
}

Joseph N. Fiore, Acting Asst. Mgr.

Office of Environmental Restoration \& Waste Management

Nevada Operations Office

U.S. Dept. of Energy

P.O. Box 98518

Las Vegas, NV 89193-8518

Joseph H. Kitchen

Technology and Program Management Division Nevada Operations Office

U.S. Dept. of Energy

P.O. Box 98518

Las Vegas, NV 89193-8518

Steve Lawrence

Environmental Restoration Division

Nevada Operations Office

U.S. Dept. of Energy

P.O. Box 98518

Las Vegas, NV 89193-8518
John S. Ledbetter

Contracts Division

Nevada Operations Office

U.S. Dept. of Energy

P.O. Box 98518, MS 505

Las Vegas, NV 89193-8518

Steve Leedom

Test Operations Division

Nevada Operations Office

U.S. Dept. of Energy

P.O. Box 98518

Las Vegas, NV 89193-8518

Steve Mellington, Director

Environmental Restoration Division

Nevada Operations Office

U.S. Dept. of Energy

P.O. Box 98518

Las Vegas, NV 89193-8518

Richard Pearl

Environmental Protection Division

Nevada Operations Office

U.S. Dept. of Energy

P.O. Box 98518

Las Vegas, NV 89193-8518

\section{U.S. Department of Defense}

David Bedsun

Defense Nuclear Agency

U.S. Department of Defense

P.O. Box 98539

Las Vegas, NV 89193-8539

\section{Lawrence Livermore National Laboratory}

Lee Davisson

Nuclear Chemistry Division

Lawrence Livermore National Laboratory

P.O. Box 808, MS L237

Livermore, CA 94550

Greg Nimz

Lawrence Livermore National Laboratory

P.O. Box 808 , MS L233

Livermore, CA 94550 


\section{Los Alamos National Laboratory}

Joe Thompson

Los Alamos National Laboratory

INC-11, MS J514

P.O. Box 1663

Los Alamos, NM 87545

\section{U.S. Geological Survey}

Virginia Glanzman

U.S. Geological Survey

Box 2506, MS 913

Denver Federal Center

Denver, CO 80225

Randy Laczniak

U.S. Geological Survey

Water Resources Division

6770 S. Paradise Rd.

Las Vegas, NV 89119

Paul Orkild

U.S. Geological Survey

Box 2506, MS 913

Denver Federal Center

Denver, CO 80225

Doug Trudeau

U.S. Geological Survey

Water Resources Division

6770 S. Paradise Rd.

Las Vegas, NV 89119

\section{Desert Research Institute}

Roger Jacobson

Desert Research Institute

Water Resources Center

P.O. Box 19040

Las Vegas, NV 89132-0040

Marjory Jones

Desert Research Institute

Water Resources Center

P.O. Box 60220

Reno, NV 89506-0220
Paul Seaber

Desert Research Institute

Water Resources Center

P.O. Box 19040

Las Vegas, NV 89132-0040

Reynolds Electrical \& Engineering Co.

Martha DeMarre

Chief, Document Research Section

Health Protection Dept.

Reynolds Electrical \& Engineering Co.

P.O. Box 98521

Las Vegas, NV 89193-8521

Brian Dozier

Reynolds Electrical \& Engineering Co.

2501 Wyandotte

Mercury, NV 89102

State of Nevada

Larry Franks

Nevada State Health Department

Radiological Health Section

620 Belrose Avenue

Las Vegas, NV 89158

\section{LIBRARIES}

Archives

Getchell Library

University of Nevada, Reno

Beverly Carter

MacKay School of Mines Library

University of Nevada, Reno

Stead Library

Desert Research Institute

Reno, Nevada

Southern Nevada Science Center

Water Resources Center, Library

P.O. Box 19040

Las Vegas, NV 89132-0040

Document Section, Library

University of Nevada, Las Vegas

4505 Maryland Parkway

Las Vegas, NV 89154 
Annie Kelley

State Documents Department

Nevada State Library

Capitol Complex

Carson City, NV 89710

Technical Information Resource Center

Nevada Operations Office

U.S. Dept. of Energy

P.O. Box 98518

Las Vegas, NV 89193-8518

Water Resources Research Archives

University of California

Room 40, North Gate Hall

Berkeley, CA 94720

\section{International Technology Corp.}

Rick Waddell

Geotrans

c/o IT

4330 Valley View

Suite 112

MS-439

Las Vegas, NV 89103

Joe Yeasted

International Technology Corp. 4330 S. Valley View, Ste. 114

Las Vegas, NV 89103 